\title{
Feed Composition For The Sodium-Bearing Waste Treatment Process
}

\author{
C. M. Barnes \\ C. B. Millet
}

January 2003

Idaho National Engineering and Environmental Laboratory Bechtel BWXT Idaho, LLC 


\title{
Feed Composition for the Sodium-Bearing Waste Treatment Process
}

\author{
C. M. Barnes \\ C. B. Millet \\ January 2003 \\ Idaho National Engineering and Environmental Laboratory \\ High-Level Waste Program Division \\ Idaho Falls, Idaho 83415
}

Prepared for the U.S. Department of Energy Under DOE Idaho Operations Office Contract DE-AC07-99ID13727 


\begin{abstract}
Treatment of sodium-bearing waste (SBW) at the Idaho Nuclear Technology and Engineering Center (INTEC) within the Idaho National Engineering and Environmental Laboratory is mandated by the Settlement Agreement between the Department of Energy and the State of Idaho. One of the requirements of the Settlement Agreement is to complete treatment of SBW by December 31, 2012. To support both design and development studies for the SBW treatment process, detailed feed compositions are needed. This report presents the expected volumes and compositions of these feed streams and the sources and assumptions used in determining them.
\end{abstract}




\section{SUMMARY}

A sodium-bearing waste (SBW) treatment facility will treat liquids and solids contained in existing tanks at the Idaho Nuclear Technology and Engineering Center (INTEC). The treatment facility may also treat additional liquid waste, called Newly Generated Liquid Waste (NGLW) that will be generated after 2005 and stored in separate tanks from the SBW. Processes currently under consideration for treating this waste include cesium ion exchange followed by grouting or adsorption, calcination using the New Waste Calcining Facility (NWCF) upgraded with additional air pollution control equipment, direct evaporation to a solidified waste, and steam reforming.

This report presents the most recent compilation of volumes and compositions of the feed streams to these potential processes. As new characterization data are received and as changes are made in INTEC Tank Farm management plans, this report will be updated. The report identifies the assumptions and source documents used in calculating the treatment process feed compositions.

Tanks WM-180 and WM-189 presently contain volumes of waste near their administrative capacities and no additions to these tanks are expected. As of November 30, 2002 Tank WM-188 contained about 210,000 gallons of waste. Approximately 75,000 gallons of additional waste will be added to Tank WM188 prior to the start of treatment. The composition presented in this report for waste in Tanks WM-180 and WM-189 is based on sample analyses; the composition of waste in Tank WM-188 is based on analyses of source streams, calculations using plant evaporator operations information, and simulation of expected future evaporation of dilute wastes.

As tanks in the Tank Farm Facility (TFF) are flushed and closed, solids will accumulate in Tank WM-187. The treatment process will process the solids in this tank as well as solids from the three SBW tanks (WM-180, WM-188, WM-189). Compositions are defined both for alternatives that process solids separately and together with SBW liquid.

Fewer data are available for tank solid compositions and quantities than for SBW liquid compositions and quantities. Compositions of solids are based on samples from four Tank Farm tanks (WM-180, WM-182, WM-183 and WM188).

Projections have been made of the volumes of NGLW streams generated prior to and during operation of the SBW treatment facility. For some of these NGLW streams, chemical composition data are available and have been used in generating treatment facility feed compositions. However, data for radionuclide concentrations in NGLW are extremely limited. Thus, radionuclide concentrations in treatment facility feeds are based solely on data from existing tank waste. Starting in FY 2006 NGLW will be collected in tanks WM-100, WM-101 and WM-102. The accumulated NGLW will later be blended with SBW for treatment in the SBW treatment facility. 


\section{CONTENTS}

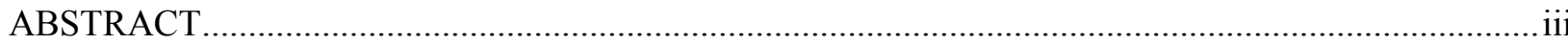

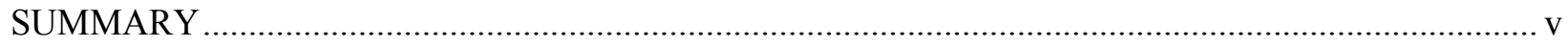

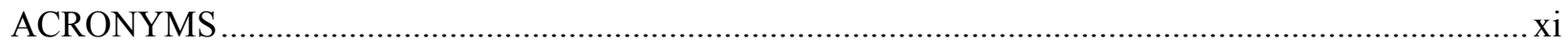

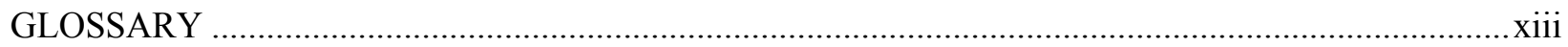

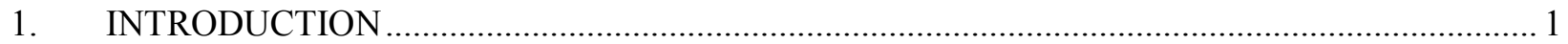



1.2 Feeds to the Alternative Treatment Processes …............................................................. 5





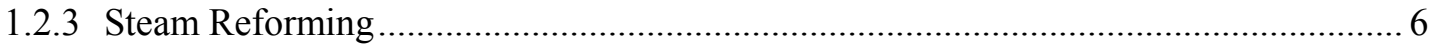

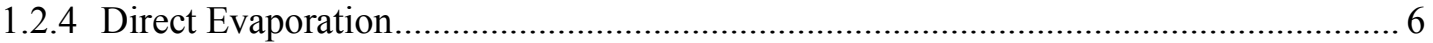

2. LIQUID WASTE COMPOSITION AND PROPERTIES …................................................. 7

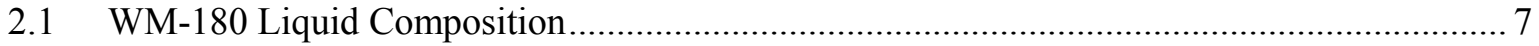

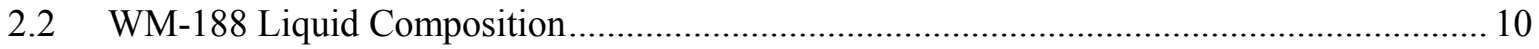

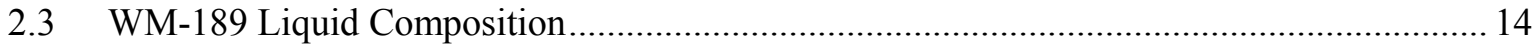



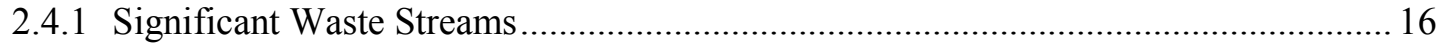

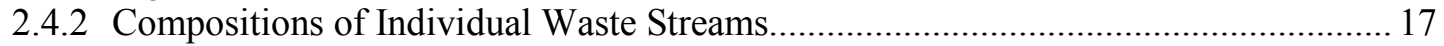

2.4.3 Composition of Combined Newly Generated Waste................................................... 26

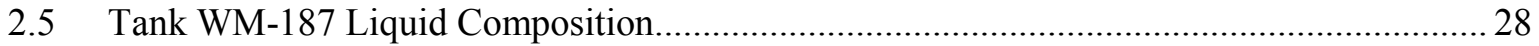

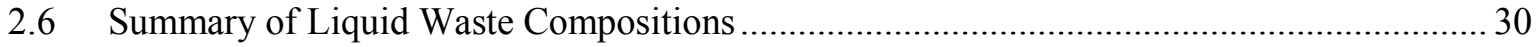



2.6.2 Liquid Composition for Solids Coprocessing Feeds ................................................... 36

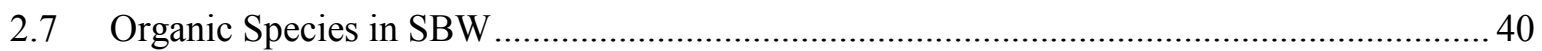

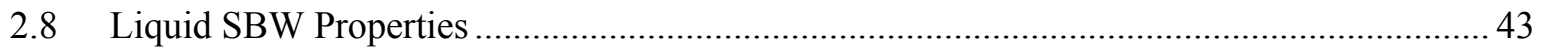

3. TANKS SOLIDS QUANTITY, COMPOSITION AND PROPERTIES ...................................... 44

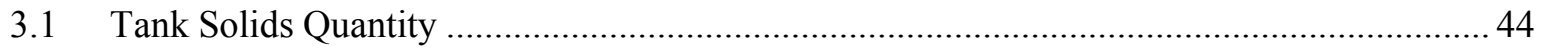

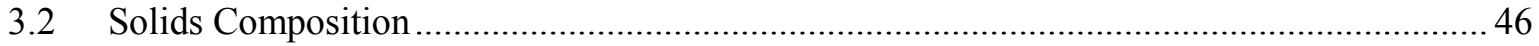




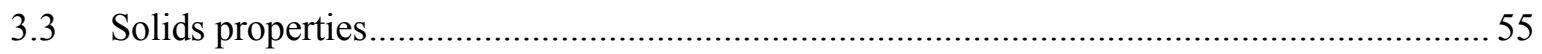

4. UNCERTAINTIES AND CHARACTERIZATION RECOMMENDATIONS ….......................... 60

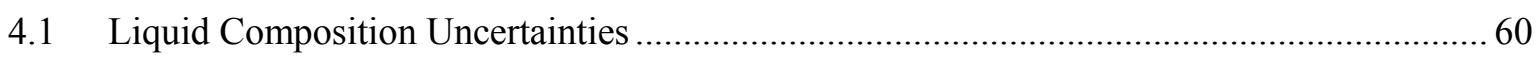

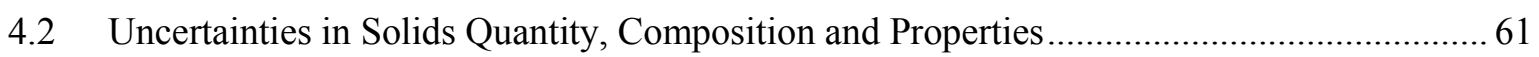



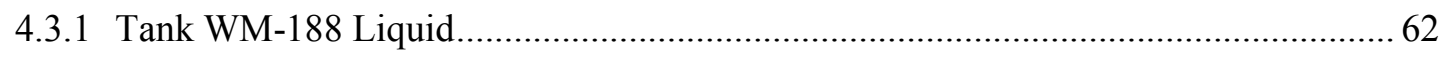

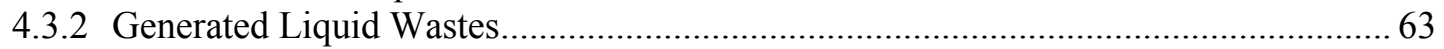

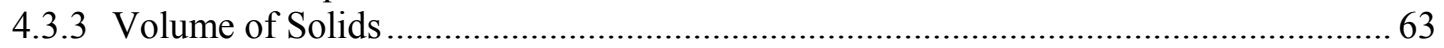

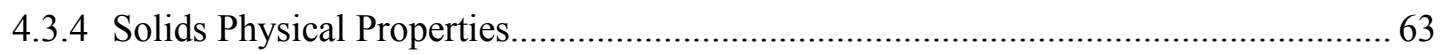

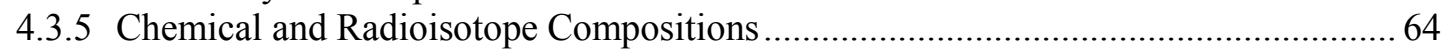

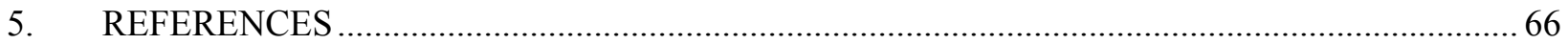

\section{FIGURES}

1. Comparison of WM-189, WM-180, WM-182, and WM-183 solids particle size distribution analyses under non-sonicated condition (from Reference 4). .................................................. 56



3. WM-189 and WM-182 Relative Volume \% Settled Sludge vs. Settling Time.............................58

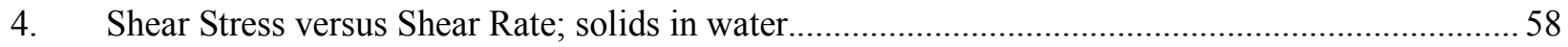

5. Shear Stress versus Shear Rate; Solids in 0.4 molar nitric acid. ..................................................5 59

\section{TABLES}



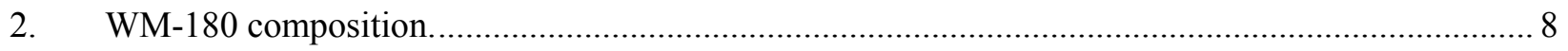

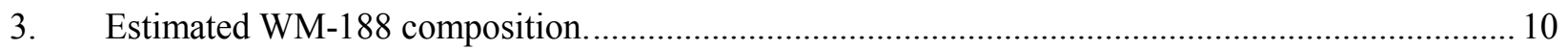

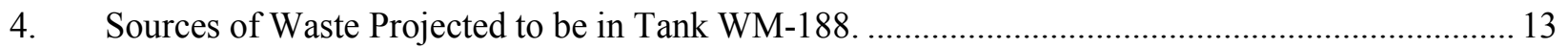

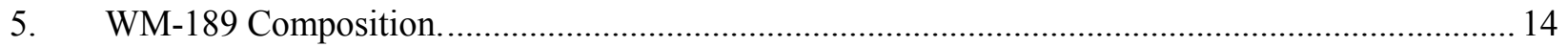



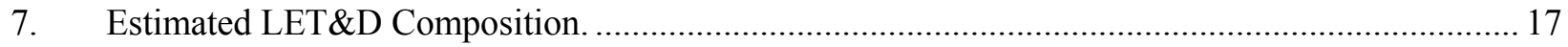




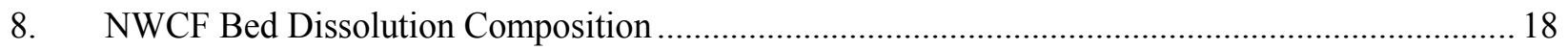

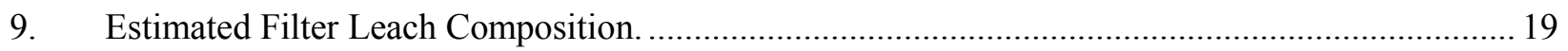

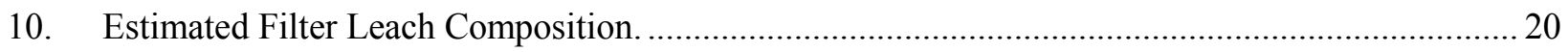

11. Estimated NWCF Operations - Adsorber Flush Composition ................................................. 21

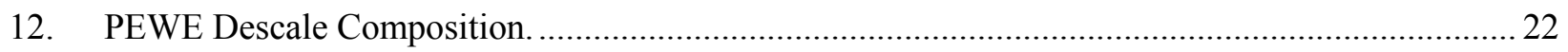



14. Estimated NWCF Operation - Deep Recycle Waste Composition..............................................2 24

15. CPP-601/627/640 Deactivation Waste Composition....................................................................... 25

16. Estimated combined generated waste (including LET\&D bottoms)............................................ 26

17. Estimated combined generated waste (excluding LET\&D bottoms). ....................................... 27

18. Estimated combined generated waste (excluding LET\&D bottoms, additional acid removal)....... 28

19. Estimated liquid composition of Tank WM-187 at time of SBW treatment................................29

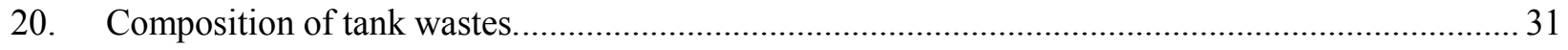

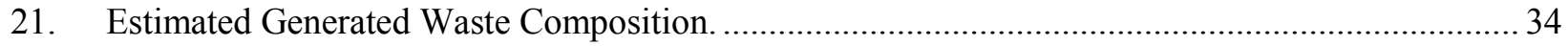



23. Coprocessing Feeds (Calcination with MACT Upgrade Alternative) …....................................... 37

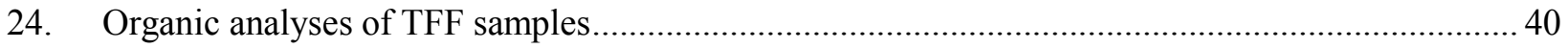

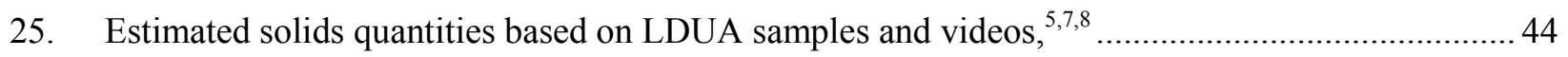

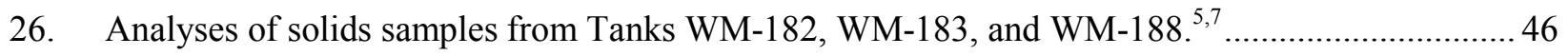

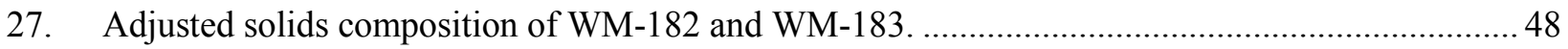

28. Adjustment factors to remove contribution of dissolved solids from solids composition of WM-



29. Estimated WM-188 solids radionuclide concentrations decayed to Jan 2003............................. 49

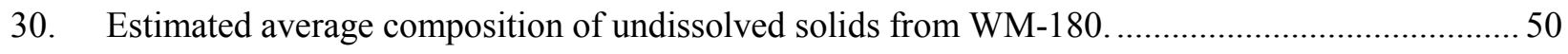

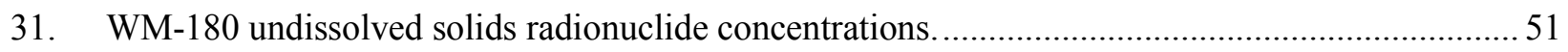

32. Composition of WM-189 sludge (combined dissolved and undissolved solids). ${ }^{4}$........................ 52

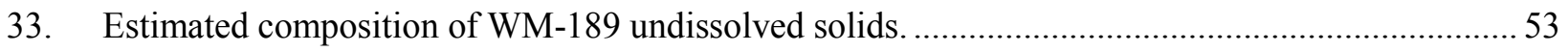


34. Estimated average composition of undissolved solids. .

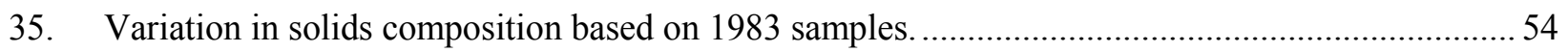




\title{
ACRONYMS
}

\author{
DEA diethanolamine \\ EDF engineering design file \\ HLLWE High-Level Liquid Waste Evaporator \\ HLW high level waste \\ ICPP Idaho Chemical Processing Plant \\ INEEL Idaho National Engineering and Environmental Laboratory \\ INTEC Idaho Nuclear Technology and Engineering Center \\ LDUA light-duty utility arm \\ LET\&D Liquid Effluent Treatment and Disposal (facility) \\ MACT maximum achievable control technology \\ NGLW newly generated liquid waste \\ NWCF New Waste Calcining Facility \\ PEW process equipment waste \\ PEWE Process Equipment Waste Evaporator \\ PSD particle size distribution \\ RCRA Resource Conservation and Recovery Act \\ SBW sodium-bearing waste \\ SG specific gravity \\ SVOCs semi-volatile organic compounds \\ TEA triethanolamine \\ TFF Tank Farm Facility \\ TIC total inorganic carbon \\ TOC total organic carbon \\ TRU transuranic \\ UDS undissolved solids \\ VOCs volatile organic compounds \\ WCF Waste Calcining Facility \\ WIR Waste Incidental to Reprocessing
}




\section{GLOSSARY}

Alternative: A holistic solution for SBW treatment, including the process / technologies used, and in the larger context the Program / Project and its cost, schedule, and regulatory and stakeholder environment.

Calcine/MACT: An SBW treatment alternative that includes the upgrades to the calciner in the NWCF, a new MACT compliance facility, a new calcine packaging facility and possibly a scrub treatment process.

"CsIX" or Cesium Ion Exchange/TRU Grout: An SBW treatment alternative that includes filtration of solids, cesium removal by ion exchange and one of several possible methods for stabilization of the cesium-free contact-handled TRU waste - grout, silica gel, or another sorbent. The baseline process is grouting and the name would change if another stabilization method were chosen.

Direct Evaporation: An SBW treatment alternative involving concentration of SBW by evaporation to the extent that it solidifies upon cooling into a disposable waste.

Heels: Initial heels left in the Tank Farm tanks consisting of concentrated SBW liquid and tank solids.

Heels, cut: Tank solids in liquid ranging from diluted SBW to water.

Newly Generated Liquid Waste: Liquid waste from a variety of sources that in the past has been evaporated and added to the liquid mixed HLW and mixed transuranic waste/SBW in the below-grade tanks at INTEC. Sources include leachates from treating contaminated high efficiency particulate air filters, decontamination liquids from INTEC operations that are not associated with HLW management activities, and liquid wastes from other INEEL facilities. INTEC has historically used this term to refer to liquid waste streams (past and future) that were not part of spent fuel reprocessing. It will be stored along with SBW in the TFF tanks until September 2005 whereupon present plans call for its segregated storage. Since it is mixed with the existing SBW in the TFF tanks it does not / will not formally exist as a separate entity until segregation starts in 2005.

Sludge: The mixture of tank solids and interstitial liquid.

Sodium Bearing Waste: The term is non-specific and can range to mean SBW liquid $+/$ - tank solids to all Tank Farm tank contents - SBW liquid and all tank solids. SBW is mixed hazardous, radioactive waste generated as a by-product of spent nuclear fuel reprocessing operations. It consists in minor part of second and third cycle extraction wastes but is mostly made up of decontamination solutions used over the years in support of operations. It is relatively high in sodium and potassium content from these decontamination solutions that are problematic to calcine - tending to cause agglomeration in the calciner bed. Hence the name, SBW, and its separate tracking and management at INTEC. SBW is high in transuranics (TRU) and is best characterized as mixed transuranic waste.

Steam Reforming: An SBW treatment alternative involving heating SBW with additives and steam to form a solid particulate waste.

Tank solids: Any and all solids contained in the Tank Farm tanks.

Tank solids, settled: Heavier tank solids that lay at the bottom of the tanks.

Tank solids, entrained: Tank solids, both suspended and settled, that are sucked up by the steam jets and transported with the liquid SBW to further treatment. 


\section{Feed Composition for the Sodium-Bearing Waste Treatment Process}

\section{INTRODUCTION}

Radioactive liquid waste has been generated over the last five decades at the Idaho Nuclear Technology and Engineering Center (INTEC), formerly called the Idaho Chemical Processing Plant (ICPP), as a result of nuclear fuel reprocessing activities. From December 1963 until June 2000, the Waste Calcining Facility (WCF) and the New Waste Calcining Facility (NWCF) processed the liquid waste into a granular, solid form. As of November 30, 2002, approximately 1,008,000 gallons of waste remained in Tank Farm tanks. Approximately $17 \%$ of the total waste presently in the tank farm is dilute waste that will be concentrated in future evaporator campaigns. Additional liquid waste will be generated in the future as a result of filter leach operations, equipment and building decontamination activities, Resource Conservation and Recovery Act (RCRA) closure activities, and other operations at INTEC.

Four processes are presently being evaluated for treating these wastes. Design and development activities are on going to select a single treatment process from the four alternatives. To support both design and development studies for the treatment processes, detailed feed compositions are needed. This report presents the expected compositions of these feed streams and the sources and methods used in estimating them.

\subsection{Source Data and Documents}

The primary sources of information used in generating projected feedstock compositions are described below.

\section{$\underline{\text { Historical and Present Tank Farm Liquid Composition }}$}

1. M. D. Staiger, C. B. Millet, R. A. Nichelson, R. A. Wood, A. Chambers, "Tank Farm Facility, Tank and Waste Data," Engineering Design File EDF-1598, February 27, 2001.

EDF-1598 contains a brief review of previous documents containing Tank Farm composition data, a compilation of Tank Farm liquid composition analytical data up through January 2000, estimates of Tank Farm solids volume, and an estimate of NGLW composition. The EDF compiles analytical results of samples taken from each of the Tank Farm tanks consistent with the liquid waste present in the tank as of late 2000. In addition, a waste composition for each tank is presented based on averages of analytical results, for those species for which data are available, and estimates for other chemical and radionuclide species. Estimates were based on calculations by Doug Wenzel using ORIGEN2 for a "typical" SBW composition and the assumption that concentrations of the estimated species for a given tank are equal to the concentration in the "typical" SBW times the ratio of ${ }^{137} \mathrm{Cs}$ in the tank waste to ${ }^{137} \mathrm{Cs}$ in the "typical" SBW. Wenzel's calculations are documented in the following reports:

D. R. Wenzel, "Evaluation of Radionuclide Inventory for Sodium-Bearing Waste," Engineering Design File EDF-FDO-006/CPP-97080, November 26, 1997.

D. R. Wenzel, “Calculation of July 1999 Inventories for INTEC Wastes," INEEL Interoffice Memorandum, Wen-27-99, originally issued November 7, 1999 and reissued with corrections August, 2000. 
D. R. Wenzel, "Calculation of July 1999 Radionuclide Inventory for Sodium-Bearing Waste," INEEL Interoffice Correspondence, Wen-20-99, May 18, 1999.

2. C. B. Millet, "Composition of Tank Farm Waste as of October 2002," INEEL Interoffice Memorandum Mil-07-02, December 12, 2002 (consistent with Excel spreadsheet "Tank Farm Composition Database 10-02d.xls").

Clark Millet maintains a spreadsheet known as the "Tank Farm Composition Database" that includes sample analyses data as well as summary concentrations for each Tank Farm tank. The tables contained in Reference 1 of both analyses data and summary averages and estimates reflect the Tank Farm Composition Database spreadsheet that was current at the time EDF-1598 was being prepared. Updates to the Tank Farm Composition Database continued after publication of EDF-1598 as described in:

D. R. Tyson, "Validation of the Radionuclide Mass Balance Used in the INTEC SBW WIR Determination Report," Engineering Design File EDF-1920, Revision 4, August 29, 2002.

In early FY 2003 the Tank Farm Composition Database was again updated to:

- Incorporate analysis data from samples taken from Tank WM-180 in 2000.

- Incorporate analysis data from samples taken from Tank WM-189 in 2002.

- $\quad$ Update the waste volumes and radionuclide decay basis from July 1, 1999 to January 1, 2003.

- $\quad$ Adjust the waste compositions in WM-182 and WM-183 due to water flushes of these tanks.

- $\quad$ Adjust the WM-185 waste composition due to additions of water and waste from WM-183 transferred in 2000 and 2001.

- $\quad$ Adjust the waste composition of WM-187 due to additions of waste to the tank in 2002.

- Incorporate additional updates by Wenzel of ORIGEN2 calculations of SBW radionuclide inventories.

While the most recent update to the Tank Farm Composition Database spreadsheet have been independently reviewed for reasonableness, they have not as yet been fully verified. Previous revisions of the spreadsheet were validated. The Tank Farm Composition Database serves as the common source and control point for all estimates of present Tank Farm liquid waste composition.

3. J. D. Christian, Composition and Simulation of Tank WM-180 Sodium-Bearing Waste at the Idaho Nuclear Technology and Engineering Center, INEEL/EXT-2001-00600, May 2001.

Jerry Christian evaluated data from samples taken in 2000 of Tank WM-180 waste and recommended a surrogate composition for waste from this tank. A comparison of the Tank WM-180 liquid composition based on 2000 sample analyses with analyses of samples taken in 1993 is given in Table 1. Reference 3 also contains compositional data for the solids in WM-180, both analytical data and results of thermodynamic modeling. 
4. T. A. Batcheller, D. D. Taylor, Characterization of Tank WM-189 Sodium-Bearing Waste at the Idaho Nuclear Technology and Engineering Center, INEEL/EXT-02-01171, September 2002. (also, Revision 1 of the same report, December 2002 draft)

Tom Batcheller and Dean Taylor evaluated liquid and solids analytical data from recent WM-189 samples and present their results in Reference 4. In addition to recommended concentration values for Tank WM-189 waste, Batcheller and Taylor present uncertainties associated with these concentrations.

\section{$\underline{\text { Tank Solids Compositions }}$}

References 3 and 4 contain analyses of solids from Tanks WM-180 and WM-189. Waste from each of these tanks was separately transferred by steam jet to a tank in the NWCF blend and hold cell, where it was sampled. Solids contained in the samples were thus solids entrained with the liquid waste during jet transfer.

5. M. Patterson, Light Duty Utility Arm Deployment in Tank WM-188, INEEL/EXT-99-01302, December 1999.

Reference 5 contains compositional data for solids that were present in WM-188 in 1999, obtained by the LDUA sample end effector.

6. Idaho Hazardous Waste Management Act/Resource Conservation and Recovery Act Closure Plan for Idaho Nuclear Technology and Engineering Center Tanks WM-182 and WM-183, DOE/IC-10802, Appendix B, "Data Summary for Tanks WM-182 and WM-183," DOE/ID-10802, November 2001.

7. A. Poloski, “Solids Characterization,” Engineering Design File EDF-TST-001, September 20, 2000 .

References 6 and 7 contain chemical and physical property data for solids that were present in the heels of Tanks WM-182 and WM-183 when sampled in 2000.

8. D. R. Tyson, "Validation of the Radionuclide Mass Balance Used in the INTEC SBW WIR

Determination Report," Engineering Design File EDF-1920, Revision 4, August 29, 2002

A summary of the inventory of radionuclides in each tank is contained in Reference 8 , which includes a significant correction to the ${ }^{137} \mathrm{Cs}$ concentration of WM-182 solids reported in Reference 7. The radionuclide inventories shown in Reference 8 for tanks other than WM-182, WM-183 and WM-188 are estimates.

9. M. C. Swenson, "Historical Tank Farm Sample Results," INEL Correspondence, MCS-27-92, December 17, 1992.

Reference 9 contains some older analyses of tank solids as well as a descriptive of sources of solids. Reference 9 also includes some data that shows how solids composition varies with particle size.

\section{$\underline{\text { Tank Solids Mass Estimate }}$}

10. A. P. Poloski, "INTEC Tank Farm Sludge Density Measurements/Calculations," Engineering Design File 15722-040, July 12, 2000. 
An estimate of the volume of "sludge" (the solids/liquid residual in a tank after removing liquid waste) by tank is given in Reference 7 . Reference 8 uses the estimated tank sludge volumes of Reference 7 plus a solids concentration from Reference 10 to derive estimates of the mass of tank solids present in each tank. Estimates of the mass of tank solids as shown in Table 12 of Reference 8 have been used in the INTEC Waste Incidental to Reprocessing (WIR Determination) and various SBW treatment mass balances made in the previous two years. New estimates are proposed in Section 3.1 for use in Conceptual Designs for SBW Treatment alternatives.

\section{NGLW Stream Compositions}

\section{J. A. Nenni, "Balance-of-Plant Sample Data Compilation," Engineering Design File, EDF-2506, September, 2002.}

Joe Nenni compiled compositional data for NGLW streams based on analysis of samples taken from FY-1999 through FY-2002. Compositional data in Reference 11 includes metals, anions, $\mathrm{pH}$ or acidity, UDS, TIC, TOC, semi volatile organic compounds and volatile organic compounds. No radionuclide data is included.

\section{J. L. Tripp, Supporting Information for the INEEL Liquid Waste Management Plan, Appendix B, INEEL/EXT-98-00730, July, 1998.}

Reference 12 contains NGLW compositional data from sample analysis prior to FY-1999. Compositions are provided by NGLW stream, and include, when available, radionuclide activities.

\section{C. M. Barnes, "NGLW Volumes and Compositions for Treatment Study," INEEL Interoffice Memorandum CMB-07-02, Rev. 1, April 8, 2002.}

Reference 13 contains estimates of the composition of several groups of NGLW streams, including streams that were thought to be high in TRU content, streams that are expected to be low in TRU content and all NGLW streams combined. Since Reference 13 was issued, new estimates of NGLW generation volumes have been made (see Reference 14). NGLW compositions shown in Section 2.4 were recalculated based on the new projections of waste volumes. However, as discussed in Section 2.4, radionuclide compositions shown in this report have been estimated based on SBW concentrations rather than NGLW analysis. Although not used to prepare NGLW composition estimates for this report, use of Reference 13 in Conceptual Design may be warranted in calculations in which small changes in NGLW radionuclide content could have impacts on the process design.

\section{Present and Future Liquid Volumes}

\section{C. M. Barnes, C. B. Millet, INTEC Tank Farm Facility Management Plan, Plan-1112,} September 30, 2002.

Present TFF volumes are based on tank level measurements. A web-based monthly update of TFF tank volumes is available at http://emhome.inel.gov/hlw/Tankdata/TankMap.htm. Reference 14 contains estimates of future tank volumes. The estimated volumes in Reference 14 do not include estimates for waste streams generated by any of the SBW treatment processes.

\section{$\underline{\text { Tank Solids Properties }}$}

Poloski (Reference 10) calculates volume fraction of solids in WM-183 sludge and also the solids particle density from measurements of the mass and volume of the sludge sample, the weight fraction of 
water in the sludge and the density of water. Reference 7 includes particle size distribution data for solids from Tanks WM-182 and WM-183 and settling rate data for solids from Tank WM-182. Reference 3 contains particle size distribution data for Tank WM-180 solids. In Reference 4, Batcheller presents particle size distribution data for solids from WM-189 as well as other solids and sludge properties.

\section{J. R. Harbour, R. F. Schumacher, A. Choi, A. K. Hansen, Development of an Initial Simulant for} the Idaho Tank Farm Solids, WSRC-TR-2002-00436, November 11, 2002.

Harbour et al used analysis data from WM-182 and WM-183 solids to develop a tank solids simulant, and then measured shear stress versus shear rate for the simulant.

\subsection{Feeds to the Alternative Treatment Processes}

Waste to be treated by the SBW Treatment Facility includes:

1. Waste (SBW) stored in Tank WM-180, including liquid and a relatively small amount of undissolved solids. Tank WM-180 is presently full (near its administrative limit) and no changes in waste composition are expected for this tank.

2. Waste (SBW) stored in Tank WM-188, including liquid and a relatively small amount of undissolved solids. Tank WM-188 is presently about three-quarters full; waste will continue to be added to the tank through 2005.

3. Waste (SBW) stored in Tank WM-189, including liquid and a relatively small amount of undissolved solids. Tank WM-189 is presently full (near its administrative limit) and no changes in waste composition are expected for this tank.

4. Waste (NGLW) that will be collected in Tanks WM-100, WM-101 and WM-102 from 2006 through the end of SBW treatment.

5. Solids stored in Tank WM-187, collected from Tanks WM-182, WM-183, WM-184, WM-185, WM-186 and WM-181. Heels from these tanks will be flushed to WM-187 using water, thus the solids in Tank WM-187 will be contained in a dilute acid/salt solution.

The following sections discuss differences in the feeds to each of the treatment processes.

\subsubsection{CsIX}

For the CsIX treatment alternative, NGLW and SBW would be blended in Treatment Facility Feed Tanks. Slurried tank solids would be received in a separate tank and treated in equipment separate from equipment that treats the liquid waste. Solids from WM-187 would be the first solids treated, followed by solids from the Tanks WM-180, WM-188 and WM-189 after these tanks have been emptied of liquid.

Thus the feeds to the CsIX/TRU Grout process will consist of liquid, containing a small amount of solids, ranging in composition from a WM-180/NGLW blend to a WM-188/NGLW blend to a WM189/NGLW blend; and a solid slurry varying in solids content and varying in composition from the composition of solids from WM-187 to the composition of solids from WM-180, WM-188, and WM-189.

The NGLW composition could change during SBW treatment. At the start of SBW treatment, the NGLW would consist of INTEC waste streams only. During SBW treatment, dilute aqueous wastes from the CsIX process would be sent to INTEC evaporators, and the concentrated waste added to the NGLW. 
Also, the NGLW generated from continued INTEC operation during the period of SBW treatment may not have the same composition as the composition of NGLW accumulated prior to treatment.

\subsubsection{Calcination/MACT}

If calcination is selected for SBW treatment, decontamination of NWCF cells could begin as early as 2004, resulting in waste not generated for the other options. This NWCF cell decontamination waste would be concentrated and added to WM-188 through FY 2005 or WM-100, WM-101 and WM-102 after 2005. Unlike the CsIX process, no dilute liquid wastes are expected to be generated continually during operation, but wastes would be generated intermittently during scheduled and unscheduled shutdowns, and also from decontamination activities after SBW processing is complete.

A separate study ${ }^{16}$ has recommended that solids be mixed with liquid tank waste in TFF tanks and processed together ("co-processed") in the calciner. In the same study several scenarios for blending solids from Tank WM-187 with wastes from the other tanks have been proposed and one recommended. Data from additional tank sampling and analyses may result in revisions to the scenario for tank blending. However, the waste feed will consist of blends of wastes from Tanks WM-180, WM-187, WM-188, WM-189, WM-100, WM-101, and WM-102. Blending will result in four distinct feeds to the treatment facility, more homogeneous in solids concentration and liquid composition than the waste in any of the individual tanks.

\subsubsection{Steam Reforming}

The waste feed to the Steam Reforming process would be nearly identical to the feed for the Calcination/MACT alternative. Minor differences in NGLW composition between these two alternatives would cause very minor differences in feed composition. Like calcination, solids would be coprocessed and transfers would be made between TFF tanks to more evenly distribute solids among the various tanks.

\subsubsection{Direct Evaporation}

Feeds to Direct Evaporation depend on two flowsheet decisions that are not final at this time. If solids were not blended with SBW liquid, the feeds would be the same as for the CsIX/TRU Grout process except for slight differences in liquid composition due to differences in NGLW composition between the two alternatives. If solids were blended, the feeds would be essentially the same as for the calcination and steam reforming alternatives. The second flowsheet uncertainty is how the evaporator condensate is treated. If the condensate were sent to the PEWE, the PEWE bottoms would be returned to the SBW treatment facility to be blended with the direct evaporation feed. Alternate condensate treatment schemes have been proposed that would eliminate processing the condensate in the PEWE and hence eliminate any recycled feed. 


\section{LIQUID WASTE COMPOSITION AND PROPERTIES}

This section discusses the sources and amounts of wastes that will be in tanks fed to the treatment process. It also projects compositions of the liquid in these tanks and the basis for calculating these compositions.

\subsection{WM-180 Liquid Composition}

Tables 1 and 2 show composition of liquid waste in Tank WM-180. Two compositions are shown in Table 1, one based on FY 2000 samples and the other based on the average of three samples taken in 1993. Approximately 280,200 gallons of waste were in WM-180 at the time of sampling in 1993. Since then, about 400 gallons of waste were added to WM-180, about 2000 gallons of water added, 4000 gallons transferred from WM-180 to WM-182 in 1997, and 2600 gallons transferred to the NWCF for sampling in 2000 . Thus, at most $1 \%$ of the difference between the two analyses can be accounted for by additions to the tank; the remainder provides an estimate of the uncertainty in the composition. While the differences between the two sets of analyses are within $\sim 10 \%$ for most major species, much larger differences are seen for some of the other species.

Table 2 presents a comprehensive composition for waste in Tank WM-180. The composition is based on averaging data from both 1993 and 2000 WM-180 samples and estimating other species. Estimates are shown by italics and are based on a 2002 update by Wenzel. ${ }^{23}$ The method for estimating concentrations of unknown species is documented in Reference 1.

Table 1. Comparison of analyses of WM-180 samples.

\begin{tabular}{lccc}
\hline & 1993 & 2000 & Ratio \\
& Mol/liter & Mol/liter & $2000 / 1993$ \\
\hline $\mathrm{H}+$ & $1.14 \mathrm{E}+00$ & $1.10 \mathrm{E}+00$ & 0.96 \\
$\mathrm{Al}$ & $5.90 \mathrm{E}-01$ & $6.63 \mathrm{E}-01$ & 1.12 \\
$\mathrm{Ba}$ & $5.10 \mathrm{E}-05$ & $5.58 \mathrm{E}-05$ & 1.09 \\
$\mathrm{~B}$ & $1.02 \mathrm{E}-02$ & $1.23 \mathrm{E}-02$ & 1.20 \\
$\mathrm{Cd}$ & $7.73 \mathrm{E}-04$ & $7.54 \mathrm{E}-04$ & 0.98 \\
$\mathrm{Ca}$ & $3.39 \mathrm{E}-02$ & $4.72 \mathrm{E}-02$ & 1.39 \\
$\mathrm{Cl}$ & $3.11 \mathrm{E}-02$ & $3.00 \mathrm{E}-02$ & 0.96 \\
$\mathrm{Cr}$ & $3.29 \mathrm{E}-03$ & $3.35 \mathrm{E}-03$ & 1.02 \\
$\mathrm{~F}$ & $4.18 \mathrm{E}-02$ & $4.74 \mathrm{E}-02$ & 1.13 \\
$\mathrm{Fe}$ & $1.75 \mathrm{E}-02$ & $2.17 \mathrm{E}-02$ & 1.24 \\
$\mathrm{~Pb}$ & $1.23 \mathrm{E}-03$ & $1.31 \mathrm{E}-03$ & 1.06 \\
$\mathrm{Hg}$ & $9.89 \mathrm{E}-04$ & $2.02 \mathrm{E}-03$ & 2.04 \\
$\mathrm{Ni}$ & $1.48 \mathrm{E}-03$ & $1.47 \mathrm{E}-03$ & 0.99 \\
$\mathrm{NO} 3$ & $4.56 \mathrm{E}+00$ & $5.01 \mathrm{E}+00$ & 1.10 \\
$\mathrm{~K}$ & $1.83 \mathrm{E}-01$ & $1.96 \mathrm{E}-01$ & 1.07 \\
$\mathrm{Se}$ & $1.04 \mathrm{E}-05$ & $1.46 \mathrm{E}-04$ & 14.0 \\
$\mathrm{Ag}$ & $4.43 \mathrm{E}-06$ & $5.29 \mathrm{E}-06$ & 1.19 \\
$\mathrm{Na}$ & $2.00 \mathrm{E}+00$ & $2.06 \mathrm{E}+00$ & 1.03 \\
$\mathrm{SO} 4$ & $4.28 \mathrm{E}-02$ & $6.98 \mathrm{E}-02$ & 1.63 \\
\hline
\end{tabular}


Table 2. WM-180 composition.

\begin{tabular}{|c|c|c|c|c|c|c|}
\hline Specific Grav & & 1.26 & & & & Mol/liter \\
\hline \multicolumn{2}{|c|}{ Undissolved Solids, $\mathrm{g} /$ liter } & 0.63 & Mercury & $\mathrm{Hg}$ & & $1.35 \mathrm{E}-03$ \\
\hline & & Mol/liter & Molybdenum & Mo & & $1.82 \mathrm{E}-04$ \\
\hline Acid & $\mathrm{H}+$ & $1.12 \mathrm{E}+00$ & Neodymium & $\mathrm{Nd}$ & & $1.59 E-05$ \\
\hline Actinium & $\mathrm{Ac}$ & $1.22 E-15$ & Neptunium & $\mathrm{Np}$ & & $9.10 E-06$ \\
\hline Aluminum & $\mathrm{Al}$ & $6.06 \mathrm{E}-01$ & Nickel & $\mathrm{Ni}$ & & $1.44 \mathrm{E}-03$ \\
\hline Americium & $\mathrm{Am}$ & $3.14 E-08$ & Niobium & $\mathrm{Nb}$ & & $3.40 E-08$ \\
\hline Antimony & $\mathrm{Sb}$ & $3.59 \mathrm{E}-08$ & Nitrate & $\mathrm{NO} 3$ & & $4.66 \mathrm{E}+00$ \\
\hline Arsenic & As & 4.71E-04 & Palladium & $\mathrm{Pd}$ & & $1.89 E-06$ \\
\hline Astatine & At & $2.91 E-28$ & Phosphate & $\mathrm{PO} 4$ & & $2.88 \mathrm{E}-03$ \\
\hline Barium & $\mathrm{Ba}$ & $5.17 \mathrm{E}-05$ & Phosphorus & $\mathrm{P}$ & & $1.29 \mathrm{E}-02$ \\
\hline Beryllium & $\mathrm{Be}$ & 7.33E-06 & Plutonium & $\mathrm{Pu}$ & & $2.03 E-06$ \\
\hline Bismuth & $\mathrm{Bi}$ & $4.41 E-18$ & Polonium & Po & & $1.45 E-18$ \\
\hline Boron & $\mathrm{B}$ & $1.08 \mathrm{E}-02$ & Potassium & $\mathrm{K}$ & & $1.84 \mathrm{E}-01$ \\
\hline Bromine & $\mathrm{Br}$ & $1.64 E-07$ & Praseodymium & $\operatorname{Pr}$ & & $4.49 E-06$ \\
\hline Cadmium & $\mathrm{Cd}$ & 7.49E-04 & Promethium & $\mathrm{Pm}$ & & $6.57 E-10$ \\
\hline Calcium & $\mathrm{Ca}$ & $3.85 \mathrm{E}-02$ & Protactinium & $\mathrm{Pa}$ & & $4.57 E-12$ \\
\hline Californium & $\mathrm{Cf}$ & $9.42 E-21$ & Radium & $\mathrm{Ra}$ & & $1.91 E-14$ \\
\hline Carbon & $\mathrm{C}$ & $1.90 E-06$ & Rhodium & $\mathrm{Rh}$ & & $1.94 E-06$ \\
\hline Cerium & $\mathrm{Ce}$ & $4.46 \mathrm{E}-05$ & Rubidium & $\mathrm{Rb}$ & & $2.98 E-06$ \\
\hline Cesium & Cs & $9.97 E-06$ & Ruthenium & $\mathrm{Ru}$ & & $1.18 \mathrm{E}-04$ \\
\hline Chloride & $\mathrm{Cl}$ & $3.00 \mathrm{E}-02$ & Samarium & $\mathrm{Sm}$ & & $2.95 E-06$ \\
\hline Chromium & $\mathrm{Cr}$ & $3.49 \mathrm{E}-03$ & Selenium & $\mathrm{Se}$ & & $1.04 \mathrm{E}-05$ \\
\hline Cobalt & Co & $1.82 \mathrm{E}-05$ & Silicon & $\mathrm{Si}$ & $<$ & $2.80 \mathrm{E}-04$ \\
\hline Copper & $\mathrm{Cu}$ & $6.57 \mathrm{E}-04$ & Silver & $\mathrm{Ag}$ & & 4.43E-06 \\
\hline Curium & $\mathrm{Cm}$ & $5.11 E-11$ & Sodium & $\mathrm{Na}$ & & $1.98 \mathrm{E}+00$ \\
\hline Dysprosium & Dy & $3.38 E-10$ & Strontium & $\mathrm{Sr}$ & & $1.12 \mathrm{E}-04$ \\
\hline Erbium & $\mathrm{Er}$ & $5.58 E-12$ & Sulfate & $\mathrm{SO} 4$ & & $5.17 \mathrm{E}-02$ \\
\hline Europium & $\mathrm{Eu}$ & $2.72 E-07$ & Sulfur & $\mathrm{S}$ & & $6.59 \mathrm{E}-02$ \\
\hline Fluoride & $\mathrm{F}$ & 4.24E-02 & Technetium & $\mathrm{Tc}$ & & $3.16 E-06$ \\
\hline Francium & $\mathrm{Fr}$ & $3.45 E-23$ & Tellurium & $\mathrm{Te}$ & & $1.55 E-06$ \\
\hline Gadolinium & $\mathrm{Gd}$ & $1.67 \mathrm{E}-04$ & Terbium & $\mathrm{Tb}$ & & $1.14 E-09$ \\
\hline Gallium & $\mathrm{Ga}$ & $1.01 E-14$ & Thallium & $\mathrm{Tl}$ & & $1.05 E-20$ \\
\hline Germanium & $\mathrm{Ge}$ & $4.73 E-09$ & Thorium & Th & & $1.06 E-10$ \\
\hline Holmium & Ho & $1.41 E-11$ & Thulium & $\mathrm{Tm}$ & & $2.64 E-15$ \\
\hline Indium & In & $7.34 E-08$ & Tin & $\mathrm{Sn}$ & & $6.33 E-08$ \\
\hline Iodine & I & $1.36 E-06$ & Titanium & $\mathrm{Ti}$ & & $5.45 \mathrm{E}-05$ \\
\hline Iron & $\mathrm{Fe}$ & $1.87 \mathrm{E}-02$ & Uranium & $\mathrm{U}$ & & $3.39 \mathrm{E}-04$ \\
\hline Lanthanum & $\mathrm{La}$ & $4.94 E-06$ & Vanadium & $\mathrm{V}$ & $<$ & $8.60 \mathrm{E}-06$ \\
\hline Lead & $\mathrm{Pb}$ & $1.32 \mathrm{E}-03$ & Ytterbium & $\mathrm{Yb}$ & & $4.93 \mathrm{E}-16$ \\
\hline Lithium & $\mathrm{Li}$ & $3.68 \mathrm{E}-04$ & Yttrium & $\mathrm{Y}$ & & $3.68 E-06$ \\
\hline Magnesium & $\mathrm{Mg}$ & $1.13 \mathrm{E}-02$ & Zinc & $\mathrm{Zn}$ & & $9.90 E-04$ \\
\hline Manganese & $\mathrm{Mn}$ & $1.33 \mathrm{E}-02$ & Zirconium & $\mathrm{Zr}$ & & $5.97 \mathrm{E}-05$ \\
\hline
\end{tabular}


Table 2. (continued).

\begin{tabular}{|c|c|c|c|c|c|}
\hline & Ci/liter & & $\mathrm{Ci} /$ liter & & $\mathrm{Ci} /$ liter \\
\hline Tl-207 & $2.00 E-11$ & U-233 & $4.15 E-11$ & Ru-106 & $4.83 E-07$ \\
\hline Tl-208 & $5.99 E-10$ & U-234 & $1.07 \mathrm{E}-06$ & Rh-102 & $4.47 E-10$ \\
\hline Tl-209 & $2.13 E-15$ & U-235 & $3.95 \mathrm{E}-08$ & Rh-106 & $4.83 E-07$ \\
\hline $\mathrm{Pb}-209$ & $9.86 E-14$ & U-236 & $5.84 \mathrm{E}-08$ & Pd-107 & $8.57 E-09$ \\
\hline $\mathrm{Pb}-210$ & $1.43 E-12$ & U-237 & $3.34 E-09$ & $\mathrm{Ag}-108 \mathrm{~m}$ & $2.21 E-13$ \\
\hline $\mathrm{Pb}-211$ & $2.01 E-11$ & U-238 & $2.34 \mathrm{E}-08$ & Ag-108 & $1.97 E-14$ \\
\hline $\mathrm{Pb}-212$ & $1.67 E-09$ & U-240 & $3.51 E-16$ & Ag-109m & $6.62 E-17$ \\
\hline $\mathrm{Pb}-214$ & $4.25 E-12$ & Np-235 & NA & $\mathrm{Ag}-110 \mathrm{~m}$ & $1.28 E-14$ \\
\hline $\mathrm{Bi}-210 \mathrm{~m}$ & $1.14 E-25$ & Np-236 & $1.59 E-12$ & Ag-110 & $1.70 E-16$ \\
\hline $\mathrm{Bi}-210$ & $1.44 E-12$ & Np-237 & $1.22 \mathrm{E}-06$ & Cd-109 & $6.62 E-17$ \\
\hline Bi-211 & $2.01 E-11$ & Np-238 & $3.95 E-11$ & Cd-113m & $1.72 E-06$ \\
\hline $\mathrm{Bi}-212$ & $1.67 E-09$ & Np-239 & $1.11 E-08$ & In-115 & $5.23 E-17$ \\
\hline Bi-213 & $9.86 E-14$ & $\mathrm{~Np}-240 \mathrm{~m}$ & $3.51 E-16$ & $\mathrm{Sn}-119 \mathrm{~m}$ & $2.60 E-15$ \\
\hline Bi-214 & $4.25 E-12$ & $\mathrm{Pu}-236$ & $1.42 E-09$ & $\mathrm{Sn}-121 \mathrm{~m}$ & $3.47 E-08$ \\
\hline Po-210 & $1.37 E-12$ & $\mathrm{Pu}-238$ & $5.71 \mathrm{E}-04$ & Sn-126 & $2.13 E-07$ \\
\hline Po-211 & $5.62 E-14$ & $\mathrm{Pu}-239$ & $8.27 \mathrm{E}-05$ & Sb-125 & $6.70 E-06$ \\
\hline Po-212 & $1.07 E-09$ & $\mathrm{Pu}-240$ & $5.26 E-06$ & $\mathrm{Sb}-126 \mathrm{~m}$ & $2.13 E-07$ \\
\hline Po-213 & $9.65 E-14$ & $\mathrm{Pu}-241$ & $1.36 E-04$ & $\mathrm{Sb}-126$ & $2.99 E-08$ \\
\hline Po-214 & $4.25 E-12$ & $\mathrm{Pu}-242$ & $4.10 E-09$ & Te-123 & $1.99 E-19$ \\
\hline Po-215 & $2.01 E-11$ & $\mathrm{Pu}-243$ & $1.13 E-17$ & $\mathrm{Te}-125 \mathrm{~m}$ & $1.63 E-06$ \\
\hline Po-216 & $1.67 E-09$ & $\mathrm{Pu}-244$ & $3.52 E-16$ & I-129 & $2.39 \mathrm{E}-08$ \\
\hline Po-218 & $4.25 E-12$ & Am-241 & 7.07E-05 & Cs-134 & $5.36 \mathrm{E}-06$ \\
\hline At-217 & $9.86 E-14$ & $\mathrm{Am}-242 \mathrm{~m}$ & $7.89 E-09$ & Cs-135 & $4.46 E-07$ \\
\hline Rn-219 & $2.01 E-11$ & Am-242 & $7.86 E-09$ & Cs-137 & $2.62 \mathrm{E}-02$ \\
\hline Rn-220 & $1.67 E-09$ & Am-243 & $1.11 E-08$ & Ba-137m & $2.48 E-02$ \\
\hline Rn-222 & $4.25 E-12$ & $\mathrm{Cm}-242$ & $6.51 E-09$ & La-138 & $9.91 E-17$ \\
\hline Fr-221 & $9.86 E-14$ & $\mathrm{Cm}-243$ & $1.47 E-08$ & Ce-142 & $1.55 E-11$ \\
\hline Fr-223 & $2.76 E-13$ & $\mathrm{Cm}-244$ & $9.15 E-07$ & Ce-144 & $3.25 E-07$ \\
\hline Ra-223 & $2.01 E-11$ & $\mathrm{Cm}-245$ & $1.55 E-10$ & Pr-144m & $3.90 E-09$ \\
\hline Ra-224 & $1.67 E-09$ & $\mathrm{Cm}-246$ & $1.02 E-11$ & Pr-144 & $3.25 E-07$ \\
\hline Ra-225 & $9.86 E-14$ & $\mathrm{Cm}-247$ & $1.13 E-17$ & Nd-144 & $8.34 E-16$ \\
\hline Ra-226 & $4.25 E-12$ & $\mathrm{Cm}-248$ & $1.20 E-17$ & Pm-146 & $2.64 E-08$ \\
\hline Ra-228 & $2.77 E-16$ & Cf-249 & $8.97 E-18$ & Pm-147 & $8.84 E-05$ \\
\hline Ac-225 & $9.86 E-14$ & Cf- 250 & $7.33 E-18$ & Sm-146 & $1.43 E-13$ \\
\hline Ac-227 & $2.00 E-11$ & Cf-251 & $1.41 E-19$ & Sm-147 & $3.82 E-12$ \\
\hline Ac-228 & $2.77 E-16$ & & & Sm-148 & $1.96 E-17$ \\
\hline Th-227 & $1.98 E-11$ & H-3 & $1.82 \mathrm{E}-05$ & Sm-149 & $1.74 E-18$ \\
\hline Th-228 & $1.66 E-09$ & Be-10 & $1.56 E-12$ & Sm-151 & $1.74 E-04$ \\
\hline Th-229 & $9.86 E-14$ & C-14 & $6.23 E-11$ & Eu-150 & $7.46 E-12$ \\
\hline Th-230 & $4.27 E-10$ & Se-79 & $2.27 E-07$ & Eu-152 & $1.31 E-06$ \\
\hline Th-231 & $1.09 E-08$ & $\mathrm{Rb}-87$ & $1.52 E-11$ & Eu-154 & 4.64E-05 \\
\hline Th-232 & $3.68 E-16$ & Sr-90 & 2.03E-02 & Eu-155 & $8.52 E-05$ \\
\hline Th-234 & $1.07 E-08$ & Y-90 & $2.03 E-02$ & Gd-152 & $7.38 E-19$ \\
\hline $\mathrm{Pa}-231$ & $4.64 E-11$ & Zr-93 & $1.15 E-06$ & Gd-153 & $3.85 E-16$ \\
\hline $\mathrm{Pa}-233$ & $1.52 E-06$ & $\mathrm{Nb}-93 \mathrm{~m}$ & $8.86 E-07$ & Ho- $166 \mathrm{~m}$ & $2.39 E-11$ \\
\hline $\mathrm{Pa}-234 \mathrm{~m}$ & $1.07 E-08$ & $\mathrm{Nb}-94$ & $5.91 E-07$ & Tm-171 & $2.61 E-16$ \\
\hline $\mathrm{Pa}-234$ & $1.40 E-11$ & Tc-98 & $1.34 E-12$ & Co-60 & $4.14 \mathrm{E}-06$ \\
\hline U-232 & $1.03 E-09$ & Tc-99 & $9.38 \mathrm{E}-06$ & Ni-63 & $2.46 \mathrm{E}-05$ \\
\hline
\end{tabular}




\subsection{WM-188 Liquid Composition}

Table 3 shows four compositions for the chemical species in Tank WM-188 waste:

1. An estimated composition of waste presently in the tank.

2. An estimated composition after additions of concentrated liquid waste from the heels of other tanks (but without additions of waste generated after 2002).

3. An estimated composition, for the calcine/MACT treatment alternative, if, in addition to concentrated waste from tank heels, an amount of generated waste, after concentration, is added that will fill the tank.

4. An estimated composition, for the other treatment alternatives, if an amount of generated waste is added that will fill the tank.

Table 3. Estimated WM-188 composition.

\begin{tabular}{|c|c|c|c|c|}
\hline & $\begin{array}{l}\text { Waste as of } \\
\text { Oct } 1,2002\end{array}$ & $\begin{array}{l}\text { Including liquid } \\
\text { from other tanks }\end{array}$ & $\begin{array}{l}\text { Including future } \\
\text { waste, NWCF }\end{array}$ & $\begin{array}{c}\text { Including future } \\
\text { waste, other alternatives }\end{array}$ \\
\hline gallons & 211,100 & 253,936 & 285,000 & 285,000 \\
\hline $\mathrm{H}^{+}$ & $3.4 \mathrm{E}+00$ & $3.2 \mathrm{E}+00$ & $3.0 \mathrm{E}+00$ & $3.0 \mathrm{E}+00$ \\
\hline $\mathrm{Al}$ & 7.6E-01 & $7.5 \mathrm{E}-01$ & $7.0 \mathrm{E}-01$ & 7.0E-01 \\
\hline $\mathrm{Am}$ & $9.2 \mathrm{E}-08$ & $1.0 \mathrm{E}-07$ & $1.0 \mathrm{E}-07$ & $1.0 \mathrm{E}-07$ \\
\hline $\mathrm{Sb}$ & $1.0 \mathrm{E}-07$ & $3.8 \mathrm{E}-07$ & $2.3 \mathrm{E}-06$ & $2.3 \mathrm{E}-06$ \\
\hline As & 3.7E-09 & $3.4 \mathrm{E}-06$ & $1.1 \mathrm{E}-05$ & $1.1 \mathrm{E}-05$ \\
\hline $\mathrm{Ba}$ & 2.4E-05 & $2.9 \mathrm{E}-05$ & $3.1 \mathrm{E}-05$ & $3.1 \mathrm{E}-05$ \\
\hline $\mathrm{Be}$ & 2.6E-11 & $9.0 \mathrm{E}-07$ & $1.2 \mathrm{E}-06$ & $1.2 \mathrm{E}-06$ \\
\hline B & 2.6E-02 & 2.6E-02 & $2.4 \mathrm{E}-02$ & 2.4E-02 \\
\hline $\mathrm{Br}$ & $4.8 \mathrm{E}-07$ & $5.3 \mathrm{E}-07$ & $5.3 \mathrm{E}-07$ & $5.3 \mathrm{E}-07$ \\
\hline $\mathrm{Cd}$ & $5.7 \mathrm{E}-03$ & $5.6 \mathrm{E}-03$ & $5.2 \mathrm{E}-03$ & $5.2 \mathrm{E}-03$ \\
\hline $\mathrm{Ca}$ & $8.8 \mathrm{E}-02$ & $8.7 \mathrm{E}-02$ & $8.0 \mathrm{E}-02$ & $8.0 \mathrm{E}-02$ \\
\hline $\mathrm{C}$ & $5.6 \mathrm{E}-06$ & $6.1 \mathrm{E}-06$ & $6.1 \mathrm{E}-06$ & $6.1 \mathrm{E}-06$ \\
\hline $\mathrm{Ce}$ & $2.8 \mathrm{E}-05$ & $3.0 \mathrm{E}-05$ & $3.0 \mathrm{E}-05$ & $3.0 \mathrm{E}-05$ \\
\hline Cs & $2.9 \mathrm{E}-05$ & $3.2 \mathrm{E}-05$ & $3.2 \mathrm{E}-05$ & $3.2 \mathrm{E}-05$ \\
\hline $\mathrm{Cl}$ & 3.3E-02 & $3.1 \mathrm{E}-02$ & $2.9 \mathrm{E}-02$ & $2.9 \mathrm{E}-02$ \\
\hline $\mathrm{Cr}$ & $6.0 \mathrm{E}-03$ & $6.4 \mathrm{E}-03$ & $6.2 \mathrm{E}-03$ & $6.2 \mathrm{E}-03$ \\
\hline Co & $6.2 \mathrm{E}-09$ & $6.0 \mathrm{E}-06$ & 8.6E-06 & $8.9 \mathrm{E}-06$ \\
\hline $\mathrm{Cu}$ & $5.2 \mathrm{E}-09$ & $7.8 \mathrm{E}-05$ & $1.1 \mathrm{E}-04$ & $1.1 \mathrm{E}-04$ \\
\hline $\mathrm{Cm}$ & $1.5 \mathrm{E}-10$ & $1.6 \mathrm{E}-10$ & $1.6 \mathrm{E}-10$ & $1.6 \mathrm{E}-10$ \\
\hline Dy & $9.9 \mathrm{E}-10$ & $1.1 \mathrm{E}-09$ & $1.1 \mathrm{E}-09$ & $1.1 \mathrm{E}-09$ \\
\hline $\mathrm{Eu}$ & 7.9E-07 & $8.7 \mathrm{E}-07$ & $8.7 \mathrm{E}-07$ & 8.7E-07 \\
\hline $\mathrm{F}$ & $1.3 \mathrm{E}-01$ & $1.3 \mathrm{E}-01$ & $1.2 \mathrm{E}-01$ & $1.2 \mathrm{E}-01$ \\
\hline $\mathrm{Gd}$ & 4.0E-07 & $4.8 \mathrm{E}-05$ & $4.8 \mathrm{E}-05$ & $4.8 \mathrm{E}-05$ \\
\hline $\mathrm{Ge}$ & $1.4 \mathrm{E}-08$ & $1.5 \mathrm{E}-08$ & $1.5 \mathrm{E}-08$ & $1.5 \mathrm{E}-08$ \\
\hline In & $2.1 \mathrm{E}-07$ & $2.4 \mathrm{E}-07$ & 2.4E-07 & $2.4 \mathrm{E}-07$ \\
\hline I & 4.0E-06 & 4.4E-06 & 4.4E-06 & 4.4E-06 \\
\hline $\mathrm{Fe}$ & $3.0 \mathrm{E}-02$ & $3.0 \mathrm{E}-02$ & $2.8 \mathrm{E}-02$ & $2.8 \mathrm{E}-02$ \\
\hline
\end{tabular}


Table 3. (continued.)

\begin{tabular}{|c|c|c|c|c|}
\hline $\mathrm{La}$ & $1.4 \mathrm{E}-05$ & $1.6 \mathrm{E}-05$ & $1.6 \mathrm{E}-05$ & $1.6 \mathrm{E}-05$ \\
\hline $\mathrm{Pb}$ & $1.1 \mathrm{E}-03$ & $1.1 \mathrm{E}-03$ & $1.1 \mathrm{E}-03$ & $1.1 \mathrm{E}-03$ \\
\hline $\mathrm{Li}$ & $6.1 \mathrm{E}-11$ & $1.7 \mathrm{E}-05$ & $1.7 \mathrm{E}-05$ & $1.7 \mathrm{E}-05$ \\
\hline $\mathrm{Mg}$ & $1.4 \mathrm{E}-02^{\mathrm{a}}$ & $7.8 \mathrm{E}-03$ & $7.8 \mathrm{E}-03$ & $7.8 \mathrm{E}-03$ \\
\hline $\mathrm{Mn}$ & 2.4E-08 & $2.1 \mathrm{E}-03$ & $5.2 \mathrm{E}-03$ & $5.0 \mathrm{E}-03$ \\
\hline $\mathrm{Hg}$ & $6.0 \mathrm{E}-03$ & 5.7E-03 & $5.5 \mathrm{E}-03$ & $5.6 \mathrm{E}-03$ \\
\hline Mo & $5.6 \mathrm{E}-05$ & 7.9E-05 & 7.9E-05 & 7.9E-05 \\
\hline $\mathrm{Nd}$ & 4.7E-05 & $5.1 \mathrm{E}-05$ & $5.1 \mathrm{E}-05$ & $5.1 \mathrm{E}-05$ \\
\hline $\mathrm{Np}$ & 2.7E-05 & $2.9 \mathrm{E}-05$ & 2.9E-05 & 2.9E-05 \\
\hline $\mathrm{Ni}$ & $3.2 \mathrm{E}-03$ & $3.4 \mathrm{E}-03$ & $3.2 \mathrm{E}-03$ & $3.2 \mathrm{E}-03$ \\
\hline $\mathrm{Nb}$ & $1.0 \mathrm{E}-07$ & $3.3 \mathrm{E}-06$ & $3.3 \mathrm{E}-06$ & $3.3 \mathrm{E}-06$ \\
\hline NO3 & $7.7 \mathrm{E}+00$ & $7.4 \mathrm{E}+00$ & $7.3 \mathrm{E}+00$ & $7.3 \mathrm{E}+00$ \\
\hline $\mathrm{Pd}$ & $5.5 \mathrm{E}-06$ & $6.1 \mathrm{E}-06$ & $6.1 \mathrm{E}-06$ & $6.1 \mathrm{E}-06$ \\
\hline $\mathrm{PO} 4$ & $5.3 \mathrm{E}-03^{\mathrm{a}}$ & $9.6 \mathrm{E}-03$ & $8.9 \mathrm{E}-03$ & $8.9 \mathrm{E}-03$ \\
\hline $\mathrm{Pu}$ & 5.9E-06 & $6.9 \mathrm{E}-06$ & $6.9 \mathrm{E}-06$ & $6.9 \mathrm{E}-06$ \\
\hline K & $2.0 \mathrm{E}-01$ & $2.0 \mathrm{E}-01$ & $2.4 \mathrm{E}-01$ & 2.4E-01 \\
\hline $\operatorname{Pr}$ & $1.3 \mathrm{E}-05$ & $1.4 \mathrm{E}-05$ & $1.4 \mathrm{E}-05$ & $1.4 \mathrm{E}-05$ \\
\hline $\mathrm{Pm}$ & $1.9 \mathrm{E}-09$ & 2.1E-09 & 2.1E-09 & 2.1E-09 \\
\hline $\mathrm{Rh}$ & 5.7E-06 & $6.2 \mathrm{E}-06$ & $6.2 \mathrm{E}-06$ & $6.2 \mathrm{E}-06$ \\
\hline $\mathrm{Rb}$ & 8.7E-06 & $9.6 \mathrm{E}-06$ & $9.6 \mathrm{E}-06$ & $9.6 \mathrm{E}-06$ \\
\hline $\mathrm{Ru}$ & $2.6 \mathrm{E}-05$ & $3.3 \mathrm{E}-05$ & $3.3 \mathrm{E}-05$ & $3.3 \mathrm{E}-05$ \\
\hline $\mathrm{Sm}$ & $8.6 \mathrm{E}-06$ & $9.5 \mathrm{E}-06$ & $9.5 \mathrm{E}-06$ & $9.5 \mathrm{E}-06$ \\
\hline $\mathrm{Se}$ & $1.3 \mathrm{E}-06$ & $2.4 \mathrm{E}-06$ & 4.3E-06 & 4.4E-06 \\
\hline $\mathrm{Ag}$ & $1.0 \mathrm{E}-07$ & $5.8 \mathrm{E}-06$ & 5.9E-06 & 5.9E-06 \\
\hline $\mathrm{Na}$ & $1.7 \mathrm{E}+00$ & $1.6 \mathrm{E}+00$ & $1.7 \mathrm{E}+00$ & $1.7 \mathrm{E}+00$ \\
\hline $\mathrm{Sr}$ & $1.5 \mathrm{E}-05$ & $2.0 \mathrm{E}-05$ & $2.0 \mathrm{E}-05$ & 2.0E-05 \\
\hline $\mathrm{SO} 4$ & $5.0 \mathrm{E}-02$ & $5.0 \mathrm{E}-02$ & 4.7E-02 & $4.8 \mathrm{E}-02$ \\
\hline Tc & $9.2 \mathrm{E}-06$ & $1.0 \mathrm{E}-05$ & $1.0 \mathrm{E}-05$ & $1.0 \mathrm{E}-05$ \\
\hline $\mathrm{Te}$ & $4.5 \mathrm{E}-06$ & $5.0 \mathrm{E}-06$ & $5.0 \mathrm{E}-06$ & $5.0 \mathrm{E}-06$ \\
\hline $\mathrm{Tb}$ & 3.3E-09 & 3.7E-09 & 3.7E-09 & 3.7E-09 \\
\hline $\mathrm{Tl}$ & $3.1 \mathrm{E}-20$ & $2.8 \mathrm{E}-07$ & $1.1 \mathrm{E}-06$ & $1.1 \mathrm{E}-06$ \\
\hline Th & $3.1 \mathrm{E}-10$ & $3.4 \mathrm{E}-10$ & $3.4 \mathrm{E}-10$ & $3.4 \mathrm{E}-10$ \\
\hline Sn & $1.8 \mathrm{E}-07$ & $9.1 \mathrm{E}-07$ & $9.1 \mathrm{E}-07$ & $9.1 \mathrm{E}-07$ \\
\hline $\mathrm{U}$ & $4.8 \mathrm{E}-04$ & 4.9E-04 & $4.5 \mathrm{E}-04$ & 4.5E-04 \\
\hline $\mathrm{V}$ & $2.5 \mathrm{E}-05^{\mathrm{a}}$ & $6.1 \mathrm{E}-06$ & $1.8 \mathrm{E}-05$ & $1.9 \mathrm{E}-05$ \\
\hline Y & $1.1 \mathrm{E}-05$ & $1.2 \mathrm{E}-05$ & $1.2 \mathrm{E}-05$ & $1.2 \mathrm{E}-05$ \\
\hline $\mathrm{Zn}$ & $6.5 \mathrm{E}-12$ & $9.5 \mathrm{E}-05$ & $1.6 \mathrm{E}-04$ & $1.7 \mathrm{E}-04$ \\
\hline $\mathrm{Zr}$ & $1.3 \mathrm{E}-02$ & $1.3 \mathrm{E}-02$ & $1.2 \mathrm{E}-02$ & $1.2 \mathrm{E}-02$ \\
\hline \multicolumn{5}{|c|}{${ }^{\mathrm{a}}$ Estimated based on analysis of samples from other tanks } \\
\hline UDS & $2.2 \mathrm{E}+00$ & $2.2 \mathrm{E}+00$ & $2.5 \mathrm{E}+00$ & $2.5 \mathrm{E}+00$ \\
\hline TOC & $2.1 \mathrm{E}-01$ & $2.1 \mathrm{E}-01$ & 8.3E-01 & 7.9E-01 \\
\hline
\end{tabular}


Table 3. (continued.)

\begin{tabular}{|c|c|c|c|c|c|}
\hline & $\begin{array}{l}\text { Waste as of } \\
\text { Oct } 1,2002\end{array}$ & $\begin{array}{c}\text { Future } \\
\text { Composition }\end{array}$ & & $\begin{array}{l}\text { Waste as of } \\
\text { Oct } 1,2002\end{array}$ & $\begin{array}{c}\text { Future } \\
\text { Composition }\end{array}$ \\
\hline & $\mathrm{Ci} /$ liter & Ci/liter & & $\mathrm{Ci} /$ liter & $\mathrm{Ci} /$ liter \\
\hline Ra-226 & $1.2 \mathrm{E}-11$ & $1.4 \mathrm{E}-11$ & Zr-93 & $3.4 \mathrm{E}-06$ & $3.7 \mathrm{E}-06$ \\
\hline Ac-227 & $5.9 \mathrm{E}-11$ & $6.4 \mathrm{E}-11$ & $\mathrm{Nb}-93 \mathrm{~m}$ & $2.6 \mathrm{E}-06$ & $2.9 \mathrm{E}-06$ \\
\hline Th-228 & 4.9E-09 & 5.3E-09 & $\mathrm{Nb}-94$ & $1.7 \mathrm{E}-06$ & $1.9 \mathrm{E}-06$ \\
\hline Th-230 & $1.2 \mathrm{E}-09$ & $1.4 \mathrm{E}-09$ & Tc-98 & $3.9 \mathrm{E}-12$ & $4.3 \mathrm{E}-12$ \\
\hline Th-232 & $1.1 \mathrm{E}-15$ & $1.2 \mathrm{E}-15$ & Tc-99 & $1.5 \mathrm{E}-05$ & $1.8 \mathrm{E}-05$ \\
\hline Th-234 & $3.1 \mathrm{E}-08$ & $3.5 \mathrm{E}-08$ & Ru-106 & $1.4 \mathrm{E}-06$ & $2.8 \mathrm{E}-06$ \\
\hline $\mathrm{Pa}-231$ & $1.4 \mathrm{E}-10$ & $1.5 \mathrm{E}-10$ & Rh-102 & $1.3 \mathrm{E}-09$ & $1.4 \mathrm{E}-09$ \\
\hline $\mathrm{Pa}-233$ & 4.4E-06 & 4.9E-06 & Pd-107 & $2.5 \mathrm{E}-08$ & 2.8E-08 \\
\hline U-232 & $3.0 \mathrm{E}-09$ & 3.3E-09 & Cd-113m & $5.0 \mathrm{E}-06$ & $5.5 \mathrm{E}-06$ \\
\hline U-233 & $1.2 \mathrm{E}-10$ & $1.3 \mathrm{E}-10$ & In-115 & $1.5 \mathrm{E}-16$ & $1.7 \mathrm{E}-16$ \\
\hline U-234 & $1.2 \mathrm{E}-06$ & $1.1 \mathrm{E}-06$ & $\mathrm{Sn}-121 \mathrm{~m}$ & $1.0 \mathrm{E}-07$ & $1.1 \mathrm{E}-07$ \\
\hline U-235 & $3.2 \mathrm{E}-08$ & 3.3E-08 & Sn-126 & $6.2 \mathrm{E}-07$ & $6.9 \mathrm{E}-07$ \\
\hline U-236 & $5.1 \mathrm{E}-08$ & 4.7E-08 & Sb-125 & $2.0 \mathrm{E}-05$ & $2.3 \mathrm{E}-05$ \\
\hline U-238 & $3.1 \mathrm{E}-08$ & $4.5 \mathrm{E}-08$ & Sb-126 & 8.7E-08 & $9.6 \mathrm{E}-08$ \\
\hline Np-236 & $4.7 \mathrm{E}-12$ & $5.1 \mathrm{E}-12$ & Te-123 & $5.8 \mathrm{E}-19$ & $6.4 \mathrm{E}-19$ \\
\hline $\mathrm{Np}-237$ & 4.4E-06 & $4.8 \mathrm{E}-06$ & Te- $125 \mathrm{~m}$ & $4.8 \mathrm{E}-06$ & $5.3 \mathrm{E}-06$ \\
\hline $\mathrm{Pu}-236$ & 4.2E-09 & 4.6E-09 & I-129 & $8.1 \mathrm{E}-08$ & $8.8 \mathrm{E}-08$ \\
\hline $\mathrm{Pu}-238$ & $5.7 \mathrm{E}-04$ & $6.7 \mathrm{E}-04$ & Cs-134 & $8.2 \mathrm{E}-05$ & $8.4 \mathrm{E}-05$ \\
\hline $\mathrm{Pu}-239$ & $8.2 \mathrm{E}-05$ & $9.0 \mathrm{E}-05$ & Cs-135 & $1.3 \mathrm{E}-06$ & $1.4 \mathrm{E}-06$ \\
\hline $\mathrm{Pu}-240$ & $1.5 \mathrm{E}-05$ & $1.7 \mathrm{E}-05$ & Cs-137 & 7.7E-02 & $8.4 \mathrm{E}-02$ \\
\hline $\mathrm{Pu}-241$ & $4.0 \mathrm{E}-04$ & $4.8 \mathrm{E}-04$ & Ba-137m & 7.2E-02 & $8.0 \mathrm{E}-02$ \\
\hline $\mathrm{Pu}-242$ & $1.2 \mathrm{E}-08$ & $1.4 \mathrm{E}-08$ & La-138 & $2.9 \mathrm{E}-16$ & $3.2 \mathrm{E}-16$ \\
\hline $\mathrm{Pu}-244$ & $1.0 \mathrm{E}-15$ & $1.1 \mathrm{E}-15$ & Ce-142 & $4.5 \mathrm{E}-11$ & $5.0 \mathrm{E}-11$ \\
\hline Am-241 & 7.6E-05 & $8.5 \mathrm{E}-05$ & Ce-144 & $9.5 \mathrm{E}-07$ & $1.7 \mathrm{E}-06$ \\
\hline Am-242m & 2.3E-08 & $2.5 \mathrm{E}-08$ & Nd-144 & $2.4 \mathrm{E}-15$ & $2.7 \mathrm{E}-15$ \\
\hline Am-243 & 3.3E-08 & 3.6E-08 & Pm-146 & 7.7E-08 & 8.5E-08 \\
\hline $\mathrm{Cm}-242$ & $1.9 \mathrm{E}-08$ & 2.1E-08 & Pm-147 & $2.6 \mathrm{E}-04$ & $2.8 \mathrm{E}-04$ \\
\hline $\mathrm{Cm}-243$ & 4.3E-08 & 4.7E-08 & Sm-146 & 4.2E-13 & $4.6 \mathrm{E}-13$ \\
\hline $\mathrm{Cm}-244$ & 2.7E-06 & $2.9 \mathrm{E}-06$ & Sm-147 & $1.1 \mathrm{E}-11$ & $1.2 \mathrm{E}-11$ \\
\hline $\mathrm{Cm}-245$ & $4.5 \mathrm{E}-10$ & $5.0 \mathrm{E}-10$ & Sm-148 & $5.7 \mathrm{E}-17$ & $6.3 \mathrm{E}-17$ \\
\hline $\mathrm{Cm}-246$ & 3.0E-11 & $3.3 \mathrm{E}-11$ & Sm-149 & $5.1 \mathrm{E}-18$ & $5.6 \mathrm{E}-18$ \\
\hline $\mathrm{Cm}-247$ & 3.3E-17 & 3.6E-17 & Sm-151 & $5.1 \mathrm{E}-04$ & $5.6 \mathrm{E}-04$ \\
\hline $\mathrm{H}-3$ & $1.7 \mathrm{E}-05$ & $2.0 \mathrm{E}-05$ & Eu-150 & $2.2 \mathrm{E}-11$ & $2.4 \mathrm{E}-11$ \\
\hline Be-10 & 4.6E-12 & $5.0 \mathrm{E}-12$ & Eu-152 & $3.8 \mathrm{E}-06$ & $4.2 \mathrm{E}-06$ \\
\hline $\mathrm{C}-14$ & $1.8 \mathrm{E}-10$ & $1.7 \mathrm{E}-10$ & Eu-154 & 2.7E-04 & $2.9 \mathrm{E}-04$ \\
\hline Se-79 & $6.6 \mathrm{E}-07$ & 7.3E-07 & Eu-155 & $2.5 \mathrm{E}-04$ & $2.4 \mathrm{E}-04$ \\
\hline Rb-87 & $4.4 \mathrm{E}-11$ & $4.9 \mathrm{E}-11$ & Gd-152 & $2.2 \mathrm{E}-18$ & $2.4 \mathrm{E}-18$ \\
\hline Sr-90 & $5.8 \mathrm{E}-02$ & $6.9 \mathrm{E}-02$ & Co-60 & $6.2 \mathrm{E}-05$ & $6.2 \mathrm{E}-05$ \\
\hline Y-90 & $5.8 \mathrm{E}-02$ & $6.9 \mathrm{E}-02$ & $\mathrm{Ni}-63$ & 4.8E-05 & $5.3 \mathrm{E}-05$ \\
\hline
\end{tabular}


Since radionuclide concentrations in NGLW, after concentration, are assumed equal to those in SBW, Table 3 shows only two sets of radionuclide concentrations - the present composition and the future composition. No estimates for the concentrations of magnesium, vanadium or phosphate are provided in the Tank Farm Composition Database (Reference 2). Values shown in Table 3 for these three species were estimated by averaging concentration for these species in other tanks.

The INTEC Tank Farm Facility Management Plan (Reference 14, PLN-1112) indicates four HLLWE campaigns in the period 2003-2005 that will fill Tank WM-188 by late 2005. Each of these campaigns will concentrate waste from Tank WM-187. Volumes of HLLWE concentrate shown in PLN-1112 were calculated using assumed concentration factors. To predict the composition of the evaporator concentrates, the process simulation program ASPEN Plus was used to model each evaporator campaign. Table 4 shows the predicted volumes using ASPEN as well as the estimates from PLN-1112.

New waste generated during this period (called "SBW" until 2005, "NGLW" after 2005) was excluded from the process simulations (and the volumes shown in the HLLWE concentrates below) because the composition of the generated waste will vary depending on the treatment alternative and depending on how the evaporators are operated. Section 2.4 discusses these variations of NGLW composition. Thus the composition shown in the second column of Table 3 does not represent waste that will actually be in the tank because it does not include generated waste, either concentrated waste added to WM-188 directly or waste added to WM-187 that is evaporated and then added in concentrated form to WM-188.

Table 4. Sources of Waste Projected to be in Tank WM-188.

\begin{tabular}{ccc}
\hline & $\begin{array}{c}\text { PLN-1112 } \\
\text { gallons }\end{array}$ & $\begin{array}{c}\text { Evap Simulation } \\
\text { gallons }\end{array}$ \\
\hline Volume 10/31/2002 & 211,100 & 211,100 \\
HLLWE Campaign & & \\
$\# 1,2003$ & 24,341 & 13,921 \\
$\# 2,2003-4$ & 9,656 & 10,687 \\
$\# 3,2004$ & 12,392 & 7,466 \\
$\# 4,2005$ & 15,388 & 10,762 \\
Subtotal & 272,877 & 253,936 \\
SBW Generated through 2005 & 11,783 & 31,064 \\
Volume August, 2005 & & \\
\hline
\end{tabular}

The first HLLWE campaign will evaporate waste from WM-187 that primarily consists of flush waters from WM-182 and WM-183. Following this campaign, Tank WM-187 will receive flush waters from WM-184 and WM-186, and this will be sent to the HLLWE in late 2003. The third HLLWE campaign will evaporate waste collected in WM-187 in 2004, primarily the flush water from cleaning Tank WM-185, along with the cut heels (see glossary) removed from WM-182, WM-183, WM-184 and WM-186 during closure activities. The fourth HLLWE campaign will evaporate flush waters collected in WM-187 from WM-181, WM-103, WM-104, WM-105, and WM-106, along with cut heel from WM-185 and WM-181. 


\subsection{WM-189 Liquid Composition}

Table 5 shows the composition of waste in WM-189. Tank WM-189 is presently near its administrative capacity limit, and hence no additions to the tank or changes to the composition are expected in the future. Estimates are shown in italics.

Table 5. WM-189 Composition.

\begin{tabular}{|c|c|c|c|c|c|c|c|c|c|}
\hline \multirow{2}{*}{$\frac{\text { Gallons }}{\text { SG }}$} & \multirow{2}{*}{$\begin{array}{c}280,100 \\
1.317 \\
\end{array}$} & \multicolumn{3}{|c|}{$\mathrm{mol} / \mathrm{liter}$} & \multirow{2}{*}{$\begin{array}{r}\mathrm{Ci} / \text { liter } \\
3.84 E-11\end{array}$} & \multicolumn{3}{|c|}{$\mathrm{Ci} /$ liter } & \multirow{2}{*}{$\frac{\mathrm{Ci} / \text { liter }}{9.24 E-07}$} \\
\hline & & $\mathrm{Np}$ & $1.74 E-05$ & $\mathrm{~Pb}-211$ & & U-236 & 7.81E-08 & Rh-106 & \\
\hline & & $\mathrm{Ni}$ & $2.32 \mathrm{E}-03$ & $\mathrm{~Pb}-212$ & $3.19 E-09$ & U-237 & $6.39 E-09$ & Pd-107 & $1.64 E-08$ \\
\hline & mol/liter & $\mathrm{Nb}$ & $6.52 E-08$ & $\mathrm{~Pb}-214$ & $8.14 E-12$ & U-238 & 4.35E-08 & $\mathrm{Ag}-108 \mathrm{~m}$ & $4.24 E-13$ \\
\hline $\mathrm{H}+$ & 2.90 & NO3 & $6.52 \mathrm{E}+00$ & $\mathrm{Bi}-210 \mathrm{~m}$ & $2.19 E-25$ & U-240 & $6.72 E-16$ & Ag-108 & $3.77 E-14$ \\
\hline Ac & $2.33 E-15$ & $\mathrm{Pd}$ & $3.61 E-06$ & $\mathrm{Bi}-210$ & $2.75 E-12$ & $\mathrm{~Np}-236$ & $3.05 E-12$ & $\mathrm{Ag}-109 \mathrm{~m}$ & $1.27 E-16$ \\
\hline $\mathrm{Al}$ & $7.12 \mathrm{E}-01$ & PO4 & $<3.05 \mathrm{E}-04$ & $\mathrm{Bi}-211$ & $3.84 E-11$ & $\mathrm{~Np}-237$ & $4.59 \mathrm{E}-07$ & $\mathrm{Ag}-110 \mathrm{~m}$ & $2.44 E-14$ \\
\hline $\mathrm{Am}$ & $6.00 E-08$ & $\mathrm{P}$ & $2.07 \mathrm{E}-03$ & $\mathrm{Bi}-212$ & $3.19 E-09$ & $\mathrm{~Np}-238$ & $7.55 E-11$ & Ag-110 & $3.25 E-16$ \\
\hline $\mathrm{Sb}$ & $7.52 \mathrm{E}-06$ & $\mathrm{Pu}$ & $3.88 E-06$ & $\mathrm{Bi}-213$ & $1.89 E-13$ & $\mathrm{~Np}-239$ & $2.13 E-08$ & Cd-109 & $1.27 E-16$ \\
\hline As & $2.42 E-09$ & Po & $2.78 E-18$ & $\mathrm{Bi}-214$ & $8.14 E-12$ & $\mathrm{~Np}-240 \mathrm{~m}$ & $6.72 E-16$ & $\mathrm{Cd}-113 \mathrm{~m}$ & $3.30 E-06$ \\
\hline At & $5.58 E-28$ & $\mathrm{~K}$ & $2.25 \mathrm{E}-01$ & Po-210 & $2.62 E-12$ & $\mathrm{Pu}-236$ & $2.72 E-09$ & In-115 & $1.00 E-16$ \\
\hline $\mathrm{Ba}$ & $5.62 \mathrm{E}-05$ & $\operatorname{Pr}$ & $8.60 E-06$ & Po-211 & $1.07 E-13$ & $\mathrm{Pu}-238$ & $3.87 \mathrm{E}-04$ & Sn-119m & $4.97 E-15$ \\
\hline $\mathrm{Be}$ & $2.02 \mathrm{E}-05$ & $\mathrm{Pm}$ & $1.26 E-09$ & Po-212 & $2.05 E-09$ & $\mathrm{Pu}-239$ & $4.35 \mathrm{E}-05$ & $\mathrm{Sn}-121 \mathrm{~m}$ & $6.64 E-08$ \\
\hline $\mathrm{Bi}$ & $8.43 E-18$ & $\mathrm{~Pa}$ & $8.74 E-12$ & Po-213 & $1.85 E-13$ & $\mathrm{Pu}-240$ & $1.01 E-05$ & Sn-126 & $4.08 E-07$ \\
\hline B & $2.12 \mathrm{E}-02$ & $\mathrm{Ra}$ & $3.65 E-14$ & Рo-214 & $8.14 E-12$ & $\mathrm{Pu}-241$ & $1.33 \mathrm{E}-02$ & Sb-125 & $1.28 E-05$ \\
\hline $\mathrm{Br}$ & $3.14 E-07$ & $\mathrm{Rh}$ & $3.71 E-06$ & Po-215 & $3.84 E-11$ & $\mathrm{Pu}-242$ & $7.85 E-09$ & $\mathrm{Sb}-126 \mathrm{~m}$ & $4.08 E-07$ \\
\hline $\mathrm{Cd}$ & $3.91 \mathrm{E}-03$ & $\mathrm{Rb}$ & $5.71 E-06$ & Рo-216 & $3.19 E-09$ & $\mathrm{Pu}-243$ & $2.15 E-17$ & $\mathrm{Sb}-126$ & $5.71 E-08$ \\
\hline $\mathrm{Ca}$ & $7.31 \mathrm{E}-02$ & $\mathrm{Ru}$ & $1.72 \mathrm{E}-04$ & Po-218 & $8.14 E-12$ & $\mathrm{Pu}-244$ & $6.73 E-16$ & Te-123 & $3.81 E-19$ \\
\hline $\mathrm{Cf}$ & $1.80 E-20$ & $\mathrm{Sm}$ & $5.65 E-06$ & At-217 & $1.89 E-13$ & Am-241 & 7.34E-05 & $\mathrm{Te}-125 \mathrm{~m}$ & $3.13 E-06$ \\
\hline $\mathrm{C}$ & $3.64 E-06$ & $\mathrm{Se}$ & $8.24 E-07$ & Rn-219 & $3.84 E-11$ & Am- $242 \mathrm{~m}$ & $1.51 E-08$ & I-129 & $5.30 E-08$ \\
\hline $\mathrm{Ce}$ & $3.51 \mathrm{E}-05$ & $\mathrm{Si}$ & $3.08 \mathrm{E}-04$ & Rn-220 & $3.19 E-09$ & Am-242 & $1.50 E-08$ & Cs-134 & 4.03E-05 \\
\hline Cs & $2.68 \mathrm{E}-05$ & $\mathrm{Ag}$ & $6.54 E-08$ & Rn-222 & $8.14 E-12$ & Am-243 & $2.13 E-08$ & Cs- 135 & $8.54 E-07$ \\
\hline $\mathrm{Cl}$ & $2.06 \mathrm{E}-02$ & $\mathrm{Na}$ & $2.04 \mathrm{E}+00$ & Fr-221 & $1.89 E-13$ & $\mathrm{Cm}-242$ & $2.98 \mathrm{E}-08$ & Cs-137 & $5.01 \mathrm{E}-02$ \\
\hline $\mathrm{Cr}$ & $5.64 \mathrm{E}-03$ & $\mathrm{Sr}$ & $1.42 \mathrm{E}-04$ & Fr-223 & $5.29 E-13$ & $\mathrm{Cm}-243$ & $2.82 E-08$ & Ba-137m & $4.74 E-02$ \\
\hline Co & $4.63 \mathrm{E}-05$ & $\mathrm{SO} 4$ & $1.07 \mathrm{E}-01$ & Ra-223 & $3.84 E-11$ & $\mathrm{Cm}-244$ & $1.05 \mathrm{E}-06$ & La-138 & $1.90 E-16$ \\
\hline $\mathrm{Cu}$ & $9.54 \mathrm{E}-04$ & $\mathrm{~S}$ & $8.58 \mathrm{E}-02$ & Ra-224 & $3.19 E-09$ & $\mathrm{Cm}-245$ & $2.96 E-10$ & $\mathrm{Ce}-142$ & $2.97 E-11$ \\
\hline $\mathrm{Cm}$ & $9.78 E-11$ & $\mathrm{Tc}$ & $6.05 E-06$ & Ra-225 & $1.89 E-13$ & $\mathrm{Cm}-246$ & $1.95 E-11$ & Ce-144 & $6.23 E-07$ \\
\hline Dy & $6.46 E-10$ & $\mathrm{Te}$ & $7.26 \mathrm{E}-06$ & Ra-226 & $8.14 E-12$ & $\mathrm{Cm}-247$ & $2.15 E-17$ & Pr- $144 \mathrm{~m}$ & $7.47 E-09$ \\
\hline $\mathrm{Er}$ & $1.07 E-11$ & $\mathrm{~Tb}$ & $2.18 E-09$ & Ra-228 & $5.31 E-16$ & $\mathrm{Cm}-248$ & $2.30 E-17$ & Pr-144 & $6.23 E-07$ \\
\hline $\mathrm{Eu}$ & $5.20 E-07$ & $\mathrm{Tl}$ & $2.00 E-20$ & Ac- 225 & $1.89 E-13$ & Cf-249 & $1.72 E-17$ & Nd-144 & $1.60 E-15$ \\
\hline $\mathrm{F}$ & $1.37 \mathrm{E}-02$ & $\mathrm{Th}$ & $3.50 \mathrm{E}-05$ & Ac- 227 & $3.83 E-11$ & Cf-250 & $1.40 E-17$ & Pm-146 & $5.05 E-08$ \\
\hline $\mathrm{Fr}$ & $6.60 E-23$ & $\mathrm{Tm}$ & $5.05 \mathrm{E}-15$ & Ac- 228 & $5.31 E-16$ & Cf-251 & $2.70 E-19$ & Pm-147 & $1.69 E-04$ \\
\hline Gd & $1.35 \mathrm{E}-04$ & $\mathrm{Sn}$ & 4.14E-05 & Th-227 & $3.79 E-11$ & & & Sm-146 & $2.74 E-13$ \\
\hline $\mathrm{Ga}$ & $1.94 E-14$ & $\mathrm{Ti}$ & $7.29 \mathrm{E}-05$ & Th-228 & $3.18 E-09$ & $\mathrm{H}-3$ & $9.66 \mathrm{E}-06$ & Sm-147 & $7.32 E-12$ \\
\hline $\mathrm{Ge}$ & $9.05 E-09$ & $\mathrm{U}$ & $5.08 \mathrm{E}-04$ & Th-229 & $1.89 E-13$ & Be-10 & $2.98 E-12$ & Sm-148 & $3.76 E-17$ \\
\hline Но & $2.71 E-11$ & $\mathrm{~V}$ & $2.51 \mathrm{E}-05$ & Th-230 & $8.17 E-10$ & C-14 & $1.19 E-10$ & Sm-149 & $3.34 E-18$ \\
\hline In & $1.40 E-07$ & $\mathrm{Yb}$ & $9.44 E-16$ & Th-231 & $2.08 E-08$ & Se-79 & $4.34 E-07$ & Sm-151 & $3.33 E-04$ \\
\hline I & $2.61 E-06$ & $\mathrm{Y}$ & $7.05 E-06$ & Th-232 & $7.04 E-16$ & $\mathrm{Rb}-87$ & $2.91 E-11$ & $\mathrm{Eu}-150$ & $1.43 E-11$ \\
\hline $\mathrm{Fe}$ & 2.69E-02 & $\mathrm{Zn}$ & $1.07 \mathrm{E}-03$ & Th-234 & $2.06 E-08$ & Sr-90 & $3.88 \mathrm{E}-02$ & $\mathrm{Eu}-152$ & $2.50 E-06$ \\
\hline $\mathrm{La}$ & $9.45 E-06$ & $\mathrm{Zr}$ & $3.56 \mathrm{E}-04$ & $\mathrm{~Pa}-231$ & $8.88 E-11$ & Y-90 & $5.11 E-02$ & Eu-154 & $1.84 \mathrm{E}-04$ \\
\hline $\mathrm{Pb}$ & $1.16 \mathrm{E}-03$ & & & $\mathrm{~Pa}-233$ & $2.91 E-06$ & $\mathrm{Zr}-93$ & $2.20 E-06$ & Eu-155 & $1.63 E-04$ \\
\hline $\mathrm{Li}$ & $3.83 \mathrm{E}-04$ & & Ci/liter & $\mathrm{Pa}-234 \mathrm{~m}$ & $2.06 E-08$ & $\mathrm{Nb}-93 \mathrm{~m}$ & $1.70 E-06$ & Gd-152 & $1.41 E-18$ \\
\hline $\mathrm{Mg}$ & $2.21 \mathrm{E}-02$ & Tl-207 & $3.83 E-11$ & $\mathrm{~Pa}-234$ & $2.67 E-11$ & $\mathrm{Nb}-94$ & $1.13 E-06$ & Gd-153 & $7.38 E-16$ \\
\hline $\mathrm{Mn}$ & $1.95 \mathrm{E}-02$ & Tl-208 & $1.15 E-09$ & U-232 & $1.97 E-09$ & Tc-98 & $2.56 E-12$ & Нo-166m & $4.57 E-11$ \\
\hline $\mathrm{Hg}$ & $6.48 \mathrm{E}-03$ & Tl-209 & $4.07 E-15$ & U-233 & $7.94 E-11$ & Tc-99 & $9.96 E-06$ & Tm-171 & $4.99 E-16$ \\
\hline Mo & $2.80 \mathrm{E}-04$ & Pb-209 & $1.89 E-13$ & U-234 & $1.74 \mathrm{E}-06$ & $\mathrm{Ru}-106$ & $9.24 E-07$ & Co-60 & $3.62 E-05$ \\
\hline $\mathrm{Nd}$ & $3.05 E-05$ & $\mathrm{~Pb}-210$ & $2.74 E-12$ & U-235 & $6.01 \mathrm{E}-08$ & Rh-102 & $8.56 E-10$ & $\mathrm{Ni}-63$ & $3.14 E-05$ \\
\hline
\end{tabular}




\subsection{Liquid Waste Generation}

The Tank Farm Management Plan (PLN-1112, Reference 14) contains projected volumes of new wastes that are expected to be generated in the future at INTEC or that could be sent to INTEC for treatment. In addition to the wastes listed in PLN-1112, a few additional wastes will be generated by a specific treatment alternative, either prior to operations or during operations. The chemical compositions of these wastes were estimated as follows:

1. The 30 expected waste streams were divided into two groups-those that made significant contributions to the total and those that did not. "Significant" was defined as contributing more than $1 \%$ to the total volume after concentration by evaporation.

2. A composition for each "significant" waste stream was obtained either from analyses or by estimation.

3. A set of waste streams and corresponding volumes was defined for each of two time periods (2003 through 2005 and 2006 through 2011) and each of the four treatment alternatives. These eight sets of waste streams reduced to four unique sets.

4. For each unique set, a combined dilute waste composition was calculated based on projected dilute generation volumes and compositions.

5. Evaporation of the dilute wastes was simulated using ASPEN Plus. An endpoint of 1.3 specific gravity (SG) for the concentrate was specified in each evaporation simulation. Simulations were made with and without water dilution, in order to evaluate the benefits of removing additional acid from the dilute wastes by adding water during evaporation.

6. An estimated concentrated volume was calculated for streams that contribute less than $1 \%$ to the total generated waste volume by dividing the total dilute volume of these streams by 2000 . The concentration factor of 2000 was the same as assumed in PLN-1112. The concentrated composition of these streams was assumed the same as that of the wastes obtained in Step 5.

7. A single composition was calculated for each set of waste streams by adding the concentrate, as predicted by the evaporator simulation, to compositions/volumes of NWCF Turnaround, NWCF Bed Dissolution and NWCF Adsorber Wash wastes.

8. Simulation of evaporation of the waste of the composition obtained in step 7 was performed again using ASPEN Plus to obtain a concentrate with a specific gravity of 1.3 for each of the 4 sets of waste streams.

9. The remainder of the waste streams (streams that are not evaporated) were added to the concentrated waste obtained in step 8 to obtain a single combined generated waste composition for each of the four sets. Because treatment alternatives may or may not recycle LET\&D bottoms, compositions were calculated both with and without the LET\&D bottoms.

Concentrations of radionuclides in generated wastes were assumed the same as SBW. As discussed in Revision 1 of this report, ${ }^{21}$ radionuclide analyses are available for only between $9-22 \mathrm{vol} \%$ of the waste generated in a given year. Applying the limited amount of radionuclide concentration data to the total generated waste could introduce significant errors, because:

(a) the radionuclide concentrations are unknown for $\sim 80-90 \%$ of the total concentrated waste,

(b) the wastes streams are generated from different processes and sources and hence not expected to be similar, and 
(c) many of the waste streams are very dilute as generated. Analytical errors would be multiplied for the concentrated waste, by factors as high as 2000 for some of the waste streams.

\subsubsection{Significant Waste Streams}

Table 6 identifies the relative importance of the different waste streams. The values shown in Table 6 were calculated by:

- $\quad$ Summing annual generation rates for each stream over the period 2003 through 2011.

- Including additional wastes generated by a specific treatment process.

- $\quad$ Estimating the volume of concentrated waste for each waste stream by using the concentration factors assumed in PLN-1112.

- $\quad$ Summing the concentrated waste volumes and ranking the streams by concentrated volume.

Table 6. Breakdown of 2003-2011 wastes by stream.

\begin{tabular}{|c|c|c|c|c|}
\hline Rank & $\begin{array}{c}\text { Percent of Total } \\
\text { Concentrated Volume }\end{array}$ & Cumulative Percent & Stream Name & Basis for Composition \\
\hline 1 & $15.94 \%$ & $15.94 \%$ & LET\&D Bottoms & Nenni, 2002 \\
\hline 2 & $15.54 \%$ & $31.48 \%$ & Tank Farm Line Flushes & Estimated \\
\hline 3 & $13.95 \%$ & $45.43 \%$ & NWCF Bed Dissolution & Estimated \\
\hline 4 & $13.33 \%$ & $58.76 \%$ & Filter Leach & Nenni, 2002 \\
\hline 5 & $12.95 \%$ & $71.71 \%$ & NWCF Decon Facility & Tripp, 1998 \\
\hline 6 & $6.38 \%$ & $78.08 \%$ & NWCF Ops-Adsorber Washes & Nenni, 2002 \\
\hline 7 & $5.98 \%$ & $84.06 \%$ & NWCF Turnaround Conc. & Estimated \\
\hline 8 & $3.19 \%$ & $87.25 \%$ & PEW Descale & Tripp, 1998 \\
\hline 9 & $2.28 \%$ & $89.52 \%$ & CPP-601 (Lab Drains) & Nenni, 2002 \\
\hline 10 & $1.99 \%$ & $91.52 \%$ & NWCF Ops-Deep Recycle & Nenni, 2002 \\
\hline 11 & $1.79 \%$ & $93.31 \%$ & CPP-601/627/640 Deactivation & Tripp, 1998 \\
\hline 12 & $1.72 \%$ & $95.03 \%$ & Vault Flush & Estimated \\
\hline 13 & $1.00 \%$ & $96.03 \%$ & NWCF cell decon & \\
\hline 14 & $0.80 \%$ & $96.82 \%$ & TRA-689 Decon Solution & \\
\hline 15 & $0.80 \%$ & $97.62 \%$ & Misc. Balance of Plant & \\
\hline 16 & $0.70 \%$ & $98.32 \%$ & NWCF Turnaround Dilute & \\
\hline 17 & $0.60 \%$ & $98.92 \%$ & CPP-603 Basin Water & \\
\hline 18 & $0.30 \%$ & $99.21 \%$ & TAN Pool Water & \\
\hline 19 & $0.24 \%$ & $99.45 \%$ & Misc. Deactivation Rinses & \\
\hline 20 & $0.15 \%$ & $99.60 \%$ & LET\&D & \\
\hline 21 & $0.14 \%$ & $99.74 \%$ & FAST Operations & \\
\hline 22 & $0.11 \%$ & $99.85 \%$ & Tank Farm Sumps & \\
\hline 23 & $0.05 \%$ & $99.90 \%$ & MTR Canal Water & \\
\hline 24 & $0.03 \%$ & $99.92 \%$ & CsIX Dilute Aqueous Waste & \\
\hline 25 & $0.04 \%$ & $99.96 \%$ & CPP-604 Sumps & \\
\hline 26 & $0.01 \%$ & $99.96 \%$ & NWCF Utility Tunnel & \\
\hline 27 & $0.01 \%$ & $99.98 \%$ & CPP-603 Operations & \\
\hline 28 & $0.01 \%$ & $99.99 \%$ & PBF Canal & \\
\hline 29 & $0.01 \%$ & $99.998 \%$ & PBF D\&D & \\
\hline 30 & $0.00 \%$ & $100.00 \%$ & TAN V-Tank & \\
\hline
\end{tabular}

Table 6 shows that 12 streams account for $95 \%$ of the total waste after concentration. Only the compositions of these 12 streams were used to estimate the combined generated waste composition. 


\subsubsection{Compositions of Individual Waste Streams}

Compositions of individual waste streams are presented in this section.

2.4.2.1 LET\&D Bottoms. Table 7 shows the estimated composition of LET\&D bottoms.

Table 7. Estimated LET\&D Composition.

\begin{tabular}{|c|c|c|c|}
\hline & Mol/liter & & \\
\hline $\mathrm{H}+$ & $1.21 \mathrm{E}+01$ & \multirow{6}{*}{$\begin{array}{l}1 \\
1\end{array}$} & \multirow{11}{*}{$\begin{array}{l}\text { 1. Gray shading indicates data contains } \\
\text { flags, typically below detection } \\
\text { limits or detected in blank } \\
\text { 2. Red shading indicates value was } \\
\text { estimated based on concentrations } \\
\text { of other known species and concentration } \\
\text { of the unknown species in SBW }\end{array}$} \\
\hline $\mathrm{Al}$ & $5.61 \mathrm{E}-02$ & & \\
\hline $\mathrm{Sb}$ & $6.92 \mathrm{E}-07$ & & \\
\hline As & $1.62 \mathrm{E}-06$ & & \\
\hline $\mathrm{Ba}$ & $9.77 \mathrm{E}-07$ & & \\
\hline $\mathrm{Be}$ & $8.65 \mathrm{E}-07$ & & \\
\hline B & $2.10 \mathrm{E}-04$ & \multirow{4}{*}{$\begin{array}{l}2 \\
1 \\
2 \\
2\end{array}$} & \\
\hline $\mathrm{Cd}$ & $1.89 \mathrm{E}-07$ & & \\
\hline $\mathrm{Ca}$ & 7.44E-04 & & \\
\hline $\mathrm{Cl}$ & $6.57 \mathrm{E}-03$ & & \\
\hline $\mathrm{Cr}$ & $1.70 \mathrm{E}-03$ & & \\
\hline Co & $1.75 \mathrm{E}-04$ & & \multirow{3}{*}{$\begin{array}{l}\text { 3. Blue shading indicates that value was } \\
\text { obtained by charge balance }\end{array}$} \\
\hline $\mathrm{Cu}$ & $8.54 \mathrm{E}-05$ & & \\
\hline $\mathrm{F}$ & $7.16 \mathrm{E}-03$ & 1 & \\
\hline $\mathrm{Fe}$ & $2.92 \mathrm{E}-04$ & 2 & \multirow{21}{*}{$\begin{array}{l}\text { No shading indicates the average of } \\
\text { analytical data for three samples. Data } \\
\text { points with qualifying flags were } \\
\text { excluded from the averages. }\end{array}$} \\
\hline $\mathrm{Pb}$ & 4.62E-07 & 1 & \\
\hline $\mathrm{Mn}$ & $5.83 \mathrm{E}-05$ & & \\
\hline $\mathrm{Hg}$ & $2.34 \mathrm{E}-04$ & & \\
\hline $\mathrm{Ni}$ & $1.94 \mathrm{E}-03$ & & \\
\hline $\mathrm{NO} 3$ & $1.23 \mathrm{E}+01$ & \multirow{16}{*}{$\begin{array}{l}3 \\
2 \\
2 \\
1 \\
1 \\
2 \\
2 \\
1 \\
1 \\
2\end{array}$} & \\
\hline $\mathrm{P}$ & 7.49E-05 & & \\
\hline K & $2.51 \mathrm{E}-03$ & & \\
\hline $\mathrm{Se}$ & $1.27 \mathrm{E}-06$ & & \\
\hline $\mathrm{Ag}$ & $1.91 \mathrm{E}-07$ & & \\
\hline $\mathrm{Na}$ & $2.40 \mathrm{E}-02$ & & \\
\hline S & $1.09 \mathrm{E}-03$ & & \\
\hline $\mathrm{Tl}$ & $5.75 \mathrm{E}-07$ & & \\
\hline $\mathrm{U}$ & $5.68 \mathrm{E}-07$ & & \\
\hline V & $1.67 \mathrm{E}-06$ & & \\
\hline $\mathrm{Zn}$ & $1.50 \mathrm{E}-05$ & & \\
\hline \multirow[t]{2}{*}{$\mathrm{Zr}$} & $2.91 \mathrm{E}-06$ & & \\
\hline & $\mathrm{g} /$ liter & & \\
\hline UDS & $2.22 \mathrm{E}-02$ & & \\
\hline TIC & $4.47 \mathrm{E}-02$ & & \\
\hline TOC & $1.41 \mathrm{E}-02$ & & \\
\hline
\end{tabular}

Estimates of species that were not analyzed were obtained by multiplying the ratio of the concentration of a given species in SBW by the average ratio of a representative species in the LET\&D bottoms to the concentration of these same species in SBW. To estimate the concentration of chloride, the 
fluoride ratio was used. The other estimated species are all nonvolatile and the average ratio for barium, manganese and zinc was used to estimate the nonvolatile species.

Samples of LET\&D bottoms were taken from the LET\&D bottoms tank, WLL-195, and were taken in 1999 and 2000. Analyses of these samples are reported in Reference 11.

2.4.2.2 Tank Farm Line Flushes. The composition of Tank Farm line flushes was assumed equal to the average SBW composition, as shown in Reference 22.

2.4.2.3 NWCF Bed Dissolution. The NWCF bed dissolution composition shown in Table 8 was calculated based on the following assumptions:

- $\quad$ Dissolution of calcine with 10 volumes of 6 molar nitric acid per volume of calcine.

- $\quad$ Calcine composition as shown in the mass balance for the calcination with MACT Upgrade alternative in Reference 19.

- $\quad 96 \%$ calcine dissolution, the remainder of calcine present in the waste as undissolved solids.

Table 8. NWCF Bed Dissolution Composition

\begin{tabular}{lc}
\hline & Mol/liter \\
\hline $\mathrm{H}+$ & $4.95 \mathrm{E}+00$ \\
$\mathrm{Al}$ & $1.50 \mathrm{E}-01$ \\
$\mathrm{Sb}$ & $9.68 \mathrm{E}-07$ \\
$\mathrm{As}$ & $8.79 \mathrm{E}-06$ \\
$\mathrm{Ba}$ & $2.80 \mathrm{E}-05$ \\
$\mathrm{Be}$ & $1.85 \mathrm{E}-07$ \\
$\mathrm{~B}$ & $5.80 \mathrm{E}-04$ \\
$\mathrm{Cd}$ & $1.44 \mathrm{E}-04$ \\
$\mathrm{Ca}$ & $3.97 \mathrm{E}-03$ \\
$\mathrm{Cl}$ & $5.97 \mathrm{E}-04$ \\
$\mathrm{Cr}$ & $1.60 \mathrm{E}-04$ \\
$\mathrm{Co}$ & $2.81 \mathrm{E}-06$ \\
$\mathrm{Cu}$ & $2.78 \mathrm{E}-05$ \\
$\mathrm{~F}$ & $2.84 \mathrm{E}-03$ \\
$\mathrm{Fe}$ & $8.20 \mathrm{E}-04$ \\
$\mathrm{~Pb}$ & $6.79 \mathrm{E}-05$ \\
$\mathrm{Mn}$ & $2.34 \mathrm{E}-04$ \\
$\mathrm{Hg}$ & $5.71 \mathrm{E}-06$ \\
$\mathrm{Ni}$ & $1.07 \mathrm{E}-04$ \\
$\mathrm{NO} 3$ & $5.47 \mathrm{E}+00$ \\
$\mathrm{P}$ & $1.38 \mathrm{E}-03$ \\
$\mathrm{~K}$ & $5.22 \mathrm{E}-03$ \\
$\mathrm{Se}$ & $8.80 \mathrm{E}-06$ \\
$\mathrm{Ag}$ & $1.21 \mathrm{E}-06$ \\
$\mathrm{Na}$ & $4.74 \mathrm{E}-02$ \\
$\mathrm{~S}$ & $1.75 \mathrm{E}-03$ \\
$\mathrm{Tl}$ & $2.10 \mathrm{E}-06$ \\
$\mathrm{U}$ & $1.27 \mathrm{E}-05$ \\
$\mathrm{~V}$ & $5.50 \mathrm{E}-06$ \\
$\mathrm{Zn}$ & $4.47 \mathrm{E}-05$ \\
$\mathrm{Zr}$ & $9.69 \mathrm{E}-04$ \\
$\mathrm{UDS}$ & \\
$\mathrm{TIC}$ & 4.36 \\
$\mathrm{TOC}$ & 0 \\
\hline & 0 \\
\hline
\end{tabular}


2.4.2.4 Filter Leach. The filter leach composition, shown in Table 9, is based on the analyses of five samples from NWCF Decontamination Tanks NCD-123 and NCD-129 taken in 1999 and 2001. The data for these samples is compiled in Reference 11. Table 9 shows the estimated composition of the filter leach waste, based on averages of data and estimates for species not analyzed. The ratio of concentration of a species in the filter leach waste to the concentration of the same species in SBW, averaged for all species measured in filter leach samples, was used to estimate concentrations of non-analyzed species.

Table 9. Estimated Filter Leach Composition.

\begin{tabular}{|c|c|c|c|}
\hline & Mol/liter & & \\
\hline $\mathrm{H}+$ & $5.45 \mathrm{E}-01$ & \multirow[b]{4}{*}{1} & \multirow{4}{*}{$\begin{array}{l}\text { 1. Gray shading indicates data contains } \\
\text { flags, typically below detection }\end{array}$} \\
\hline $\mathrm{Al}$ & $1.83 \mathrm{E}-03$ & & \\
\hline $\mathrm{Sb}$ & $5.54 \mathrm{E}-06$ & & \\
\hline As & $1.49 \mathrm{E}-06$ & & \\
\hline $\mathrm{Ba}$ & $8.49 \mathrm{E}-06$ & \multirow[b]{2}{*}{1} & \multirow[t]{2}{*}{ limits or detected in blank } \\
\hline $\mathrm{Be}$ & $1.33 \mathrm{E}-07$ & & \\
\hline $\mathrm{B}$ & $6.35 \mathrm{E}-04$ & 2 & \multirow{5}{*}{$\begin{array}{l}\text { 2. Red shading indicates value was } \\
\text { estimated based on concentrations } \\
\text { of other known species and concentratior } \\
\text { of the unknown species in SBW }\end{array}$} \\
\hline $\mathrm{Cd}$ & $1.34 \mathrm{E}-06$ & & \\
\hline $\mathrm{Ca}$ & $2.25 \mathrm{E}-03$ & 2 & \\
\hline $\mathrm{Cl}$ & $8.54 \mathrm{E}-04$ & 2 & \\
\hline $\mathrm{Cr}$ & $6.08 \mathrm{E}-05$ & & \\
\hline Co & $3.75 \mathrm{E}-07$ & 1 & \multirow{3}{*}{$\begin{array}{l}\text { 3. Blue shading indicates that value was } \\
\text { obtained by charge balance }\end{array}$} \\
\hline $\mathrm{Cu}$ & $1.96 \mathrm{E}-05$ & & \\
\hline $\mathrm{F}$ & $2.15 \mathrm{E}-03$ & 1 & \\
\hline $\mathrm{Fe}$ & 8.84E-04 & \multirow[t]{5}{*}{2} & \multirow{21}{*}{$\begin{array}{l}\text { No shading indicates the average of } \\
\text { analytical data for five samples. Data } \\
\text { points with qualifying flags were } \\
\text { excluded from the averages. }\end{array}$} \\
\hline $\mathrm{Pb}$ & $8.45 \mathrm{E}-06$ & & \\
\hline $\mathrm{Mn}$ & $2.11 \mathrm{E}-04$ & & \\
\hline $\mathrm{Hg}$ & 4.13E-06 & & \\
\hline $\mathrm{Ni}$ & $2.86 \mathrm{E}-05$ & & \\
\hline NO3 & $6.57 \mathrm{E}-01$ & $3^{3}$ & \\
\hline$P$ & $2.26 \mathrm{E}-04$ & \multirow{2}{*}{$2^{2}$} & \\
\hline K & $7.60 \mathrm{E}-03$ & & \\
\hline $\mathrm{Se}$ & $1.33 \mathrm{E}-06$ & \multirow{2}{*}{1} & \\
\hline $\mathrm{Ag}$ & $7.12 \mathrm{E}-07$ & & \\
\hline $\mathrm{Na}$ & $7.26 \mathrm{E}-02$ & 2 & \\
\hline S & $3.31 \mathrm{E}-03$ & 2 & \\
\hline $\mathrm{Tl}$ & $5.79 \mathrm{E}-07$ & 1 & \\
\hline $\mathrm{U}$ & $1.16 \mathrm{E}-06$ & \multirow{2}{*}{$\begin{array}{l}1 \\
1\end{array}$} & \\
\hline $\mathrm{V}$ & $8.42 \mathrm{E}-07$ & & \\
\hline $\mathrm{Zn}$ & $1.38 \mathrm{E}-04$ & \multirow{3}{*}{2} & \\
\hline $\mathrm{Zr}$ & $8.79 \mathrm{E}-06$ & & \\
\hline & $\mathrm{g} /$ liter & & \\
\hline UDS & $1.50 \mathrm{E}-02$ & & \\
\hline TIC & $5.88 \mathrm{E}-02$ & & \\
\hline TOC & 7.03E-01 & & \\
\hline
\end{tabular}


2.4.2.5 NWCF Decon Facility. Compositional data from 1997 for the NWCF Decon Facility Waste is contained in Reference 12. The data includes low, average and high concentration values for six chemical species plus TIC, TOC and UDS. Averages were based on from 6 to 20 data points depending on the specie. Table 10 shows these averages plus estimates for other species. Estimates were based either on the SBW or the PEWE descale composition. Estimates based on SBW were calculated by multiplying the SBW concentration for that specie by the average ratio of decon facility $\mathrm{Al}$ and $\mathrm{U}$ concentration to SBW Al and U concentration. Since the makeup NWCF Decon solution uses the same chemicals as the PEWE descale (see Section 2.4.2.8), concentrations of the major metal species in the chemicals (Na, K, $\mathrm{Cr}$, and Mn) were assumed the same for the NWCF Decon Facility waste as for the PEWE Descale waste. Table 10 shows the estimated composition of the NWCF Decon Facility waste.

Table 10. Estimated Filter Leach Composition.

\begin{tabular}{|c|c|c|c|}
\hline \multicolumn{4}{|c|}{ Mol/liter } \\
\hline $\mathrm{H}+$ & 7.41E-01 & & \\
\hline $\mathrm{Al}$ & $1.23 \mathrm{E}-02$ & & \\
\hline $\mathrm{Sb}$ & 4.29E-07 & 2 & \\
\hline As & $2.80 \mathrm{E}-06$ & 2 & 1. Green shading indicates estimate based \\
\hline $\mathrm{Ba}$ & 8.47E-07 & 2 & on PEWE descale makeup formulation. \\
\hline $\mathrm{Be}$ & $2.36 \mathrm{E}-07$ & 2 & \\
\hline B & $2.71 \mathrm{E}-04$ & 2 & 2. Red shading indicates value was \\
\hline $\mathrm{Cd}$ & 4.14E-05 & 2 & estimated based on concentrations \\
\hline $\mathrm{Ca}$ & $9.59 \mathrm{E}-04$ & 2 & of other known species and concentration \\
\hline $\mathrm{Cl}$ & $1.34 \mathrm{E}-03$ & & of the unknown species in SBW \\
\hline $\mathrm{Cr}$ & $1.16 \mathrm{E}-03$ & 1 & \\
\hline Co & $5.48 \mathrm{E}-07$ & 2 & 3. Blue shading indicates that value was \\
\hline $\mathrm{Cu}$ & $1.30 \mathrm{E}-05$ & 2 & obtained by charge balance \\
\hline $\mathrm{F}$ & $6.21 \mathrm{E}-03$ & & \\
\hline $\mathrm{Fe}$ & $3.77 \mathrm{E}-04$ & 2 & No shading indicates the average of \\
\hline $\mathrm{Pb}$ & $1.84 \mathrm{E}-05$ & 2 & analytical data. \\
\hline Mn & $6.12 \mathrm{E}-03$ & 1 & \\
\hline $\mathrm{Hg}$ & $2.17 \mathrm{E}-05$ & & \\
\hline $\mathrm{Ni}$ & $3.03 \mathrm{E}-05$ & 2 & \\
\hline NO3 & $1.45 \mathrm{E}+00$ & 3 & \\
\hline $\mathrm{P}$ & $9.65 \mathrm{E}-05$ & & \\
\hline $\mathrm{K}$ & $1.17 \mathrm{E}-01$ & 1 & \\
\hline $\mathrm{Se}$ & 8.19E-07 & 2 & \\
\hline Ag & 2.97E-08 & 2 & \\
\hline $\mathrm{Na}$ & $5.25 \mathrm{E}-01$ & 1 & \\
\hline $\mathrm{S}$ & $9.99 \mathrm{E}-04$ & & \\
\hline $\mathrm{Tl}$ & 2.29E-07 & 2 & \\
\hline $\mathrm{U}$ & $5.55 \mathrm{E}-06$ & & \\
\hline $\mathrm{V}$ & $5.42 \mathrm{E}-06$ & 2 & \\
\hline $\mathrm{Zn}$ & $1.61 \mathrm{E}-05$ & 2 & \\
\hline $\mathrm{Zr}$ & 3.75E-06 & 2 & \\
\hline & $\mathrm{g} /$ liter & & \\
\hline UDS & 0.79 & & \\
\hline TIC & & & \\
\hline TOC & 0.67 & & \\
\hline
\end{tabular}


2.4.2.6 NWCF Operations - Adsorber Flushes. The NWCF Adsorbers are typically flushed with 2-4 molar nitric acid. The composition of the Adsorber flush was assumed to be related to that of the NWCF Non-Fluoride Hot Sump Tank, NCC-122, as sampled in 1999 and 2000. NCC-122 collects cell waste from cell floor drains, off-gas compressor intercoolers, and other dilute NWCF wastes. A composition for the Adsorber waste was estimated by multiplying concentrations of NCC-122 contents by the ratio of expected acid concentration for the adsorber waste ( 3 molar) to the acid concentration of NCC-122 samples. As for previous wastes, concentrations of some species for which there were no analyses were estimated based on SBW. Table 11 shows the estimated Adsorber flush composition.

Table 11. Estimated NWCF Operations - Adsorber Flush Composition

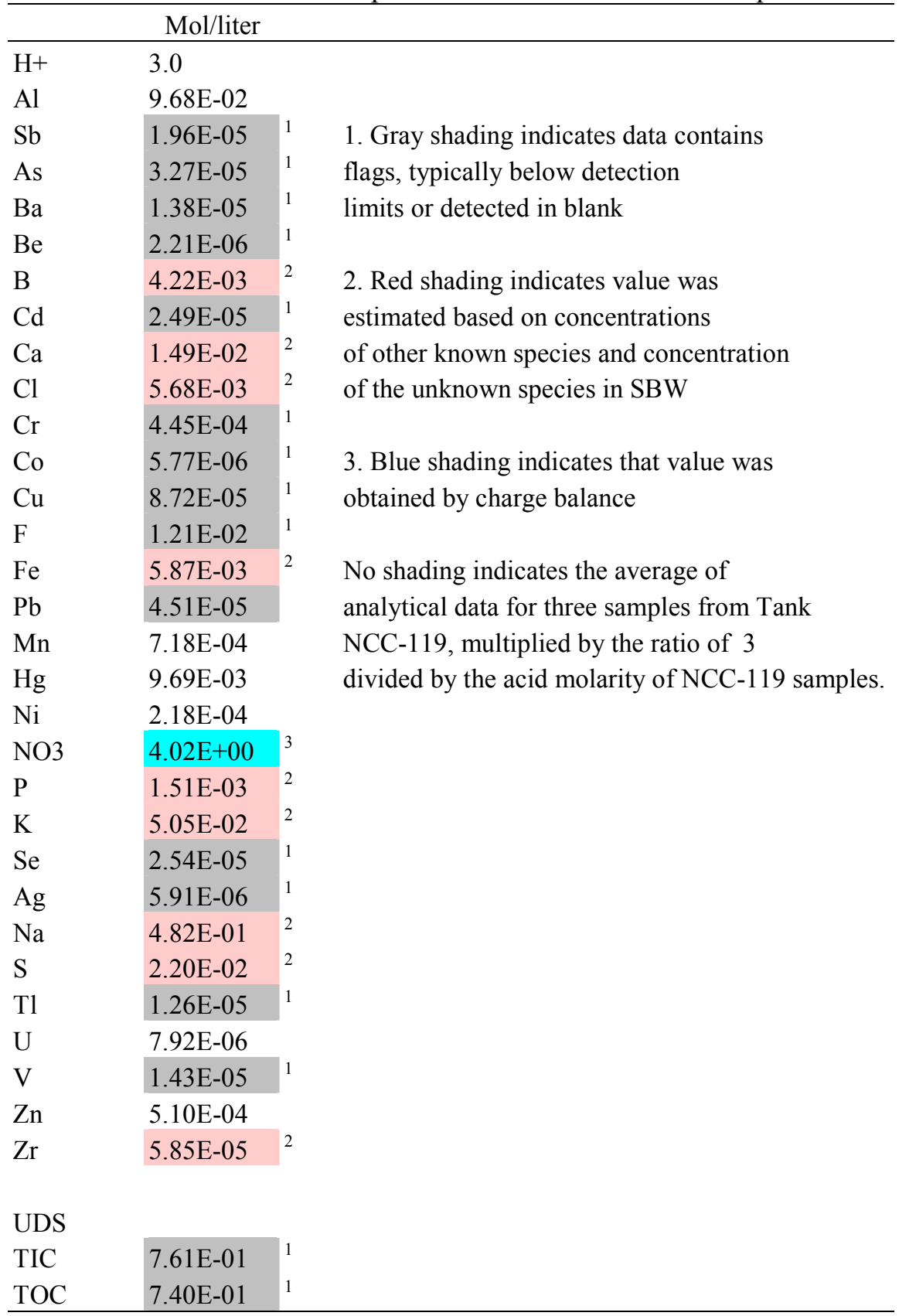


2.4.2.7 NWCF Turnaround Concentrated Waste. The composition of the NWCF turnaround concentrated waste is assumed to be equal to, after concentrating the volume to one-half the original, the composition of the NWCF bed dissolution waste.

2.4.2.8 PEWE Descale. The PEWE descale waste composition is based on the following make-up formulation given in Reference 12:

- $\quad 300$ gallons TURCO ARR diluted with water to $2 \mathrm{lb} /$ gal (TURCO ARR assumed to be $70 \mathrm{wt} \%$ $\mathrm{NaOH}, 15 \mathrm{wt} \%$ triethanolamine, $5 \mathrm{wt} \%$ diethanolamine and $5 \mathrm{wt} \%$ kerosene)

- 300 gallons TURCO 4502 diluted with water to $0.5 \mathrm{lb} / \mathrm{gal}$ (TURCO 4502 assumed to be $77 \mathrm{wt} \%$ $\mathrm{KOH}, 20 \mathrm{wt} \% \mathrm{KMnO}_{4}, 2 \mathrm{wt} \% \mathrm{~K}_{2} \mathrm{CrO}_{3}$ )

- $\quad 300$ gal oxalic acid solution at $0.5 \mathrm{lb}$ oxalic acid per gallon

- $\quad 300$ gal $6 \mathrm{~N} \mathrm{HNO}_{3}$.

Table 12 lists the composition calculated using the above formulation.

Table 12. PEWE Descale Composition.

\begin{tabular}{ll}
\hline & mol/liter \\
\hline $\mathrm{H}+$ & $1.22 \mathrm{E}-01$ \\
$\mathrm{NO}-$ & $7.92 \mathrm{E}-01$ \\
$\mathrm{~K}$ & $1.17 \mathrm{E}-01$ \\
$\mathrm{Mn}$ & $6.12 \mathrm{E}-03$ \\
$\mathrm{Cr}$ & $1.16 \mathrm{E}-03$ \\
$\mathrm{Na}$ & $5.25 \mathrm{E}-01$ \\
& $\mathrm{~g} / \mathrm{liter}$ \\
Oxalic acid & 7.50 \\
Kerosene & 1.50 \\
TEA & 4.50 \\
DEA & 1.50 \\
TOC & 14.99 \\
\hline
\end{tabular}

2.4.2.9 CPP-601 - Lab Drains. Nenni (Reference 11) reports analytical data for sixteen samples from the CPP-601 Deep Tanks, and averages of these data are shown in Table 13. Additional data from earlier samples are available in Reference 12 but were not used. Table 13 also shows the composition range of this waste stream. 
Table 13. CPP-601 Deep Tank waste

\begin{tabular}{|c|c|c|c|c|c|}
\hline \multirow{2}{*}{\multicolumn{2}{|c|}{ Mol/liter }} & \multicolumn{2}{|c|}{$\begin{array}{c}\text { Range of concentration } \\
\text { Relative to average }\end{array}$} & & \\
\hline & & Max/Ave & Min/Ave & & \\
\hline $\mathrm{H}+$ & $3.57 \mathrm{E}-01$ & $+96 \%$ & $-63 \%$ & 1 & \\
\hline $\mathrm{Al}$ & $4.28 \mathrm{E}-03$ & $+340 \%$ & $-81 \%$ & & \\
\hline $\mathrm{Sb}$ & $3.30 \mathrm{E}-07$ & $+159 \%$ & $-90 \%$ & 1 & 1. Gray shading indicates data contains \\
\hline As & $2.61 \mathrm{E}-07$ & $+205 \%$ & $-80 \%$ & 1 & flags, typically below detection \\
\hline $\mathrm{Ba}$ & $1.35 \mathrm{E}-06$ & $+270 \%$ & $-62 \%$ & & limits or detected in blank \\
\hline $\mathrm{Be}$ & $5.89 \mathrm{E}-07$ & $+354 \%$ & $-81 \%$ & & \\
\hline $\mathrm{B}$ & $1.15 \mathrm{E}-04$ & & & 2 & 2. Red shading indicates value was \\
\hline $\mathrm{Cd}$ & $1.54 \mathrm{E}-06$ & $+323 \%$ & $-77 \%$ & & estimated based on concentrations \\
\hline $\mathrm{Ca}$ & 4.08E-04 & & & 2 & of other known species and concentration \\
\hline $\mathrm{Cl}$ & $2.97 \mathrm{E}-03$ & $+20 \%$ & $-20 \%$ & & of the unknown species in SBW \\
\hline $\mathrm{Cr}$ & $1.77 \mathrm{E}-05$ & $+111 \%$ & $-53 \%$ & & \\
\hline Co & $1.13 \mathrm{E}-06$ & $+173 \%$ & $-47 \%$ & & 3. Blue shading indicates that value was \\
\hline $\mathrm{Cu}$ & $1.11 \mathrm{E}-05$ & $+60 \%$ & $-59 \%$ & & obtained by charge balance \\
\hline $\mathrm{F}$ & $1.15 \mathrm{E}-03$ & $+111 \%$ & $-40 \%$ & 1 & \\
\hline $\mathrm{Fe}$ & $1.60 \mathrm{E}-04$ & & & 2 & No shading indicates the average of \\
\hline $\mathrm{Pb}$ & $3.28 \mathrm{E}-06$ & $+306 \%$ & $-80 \%$ & & analytical data for sixteen samples. Data \\
\hline $\mathrm{Mn}$ & $1.46 \mathrm{E}-05$ & $+103 \%$ & $-54 \%$ & & points with qualifying flags were \\
\hline $\mathrm{Hg}$ & $1.14 \mathrm{E}-05$ & $+206 \%$ & $-89 \%$ & & excluded from the averages. \\
\hline $\mathrm{Ni}$ & $9.09 \mathrm{E}-06$ & $+60 \%$ & $-44 \%$ & & \\
\hline NO3 & $3.86 \mathrm{E}-01$ & & & 3 & \\
\hline $\mathrm{P}$ & $4.11 \mathrm{E}-05$ & & & 2 & \\
\hline $\mathrm{K}$ & $1.38 \mathrm{E}-03$ & & & 2 & \\
\hline $\mathrm{Se}$ & $1.73 \mathrm{E}-07$ & $+96 \%$ & $-77 \%$ & 1 & \\
\hline $\mathrm{Ag}$ & 5.15E-07 & $+640 \%$ & $-92 \%$ & 1 & \\
\hline $\mathrm{Na}$ & $1.32 \mathrm{E}-02$ & & & 2 & \\
\hline $\mathrm{S}$ & 5.99E-04 & & & 2 & \\
\hline $\mathrm{Tl}$ & 7.87E-08 & $+77 \%$ & $-72 \%$ & 1 & \\
\hline $\mathrm{U}$ & $1.06 \mathrm{E}-06$ & $+97 \%$ & $-44 \%$ & & \\
\hline $\mathrm{V}$ & $1.92 \mathrm{E}-07$ & $+139 \%$ & $-79 \%$ & 1 & \\
\hline $\mathrm{Zn}$ & 2.99E-05 & $+382 \%$ & $-68 \%$ & & \\
\hline $\mathrm{Zr}$ & $1.59 \mathrm{E}-06$ & & & 2 & \\
\hline & $\mathrm{g} /$ liter & & & & \\
\hline UDS & $1.05 \mathrm{E}-01$ & $+185 \%$ & $-97 \%$ & & \\
\hline TIC & $1.90 \mathrm{E}-02$ & $+145 \%$ & $-82 \%$ & 1 & \\
\hline TOC & $1.24 \mathrm{E}-01$ & $+113 \%$ & $-65 \%$ & & \\
\hline
\end{tabular}


2.4.2.10 NWCF Operations - Deep Recycle. Table 14 shows an estimated composition of the Deep Recycle. The composition is based on analysis of 13 samples from the NWCF Fluoride Hot Sump Tank, NCC-119, taken from December 1998 to March 2000, plus daily logs of NWCF scrub composition from May 14, 1998 to April 8, 1999 and from March 7, 2000 to May 28, 2000. For concentrations derived solely from NCC-119 analyses, Table 14 shows the standard deviation of the data points.

Table 14. Estimated NWCF Operation - Deep Recycle Waste Composition.

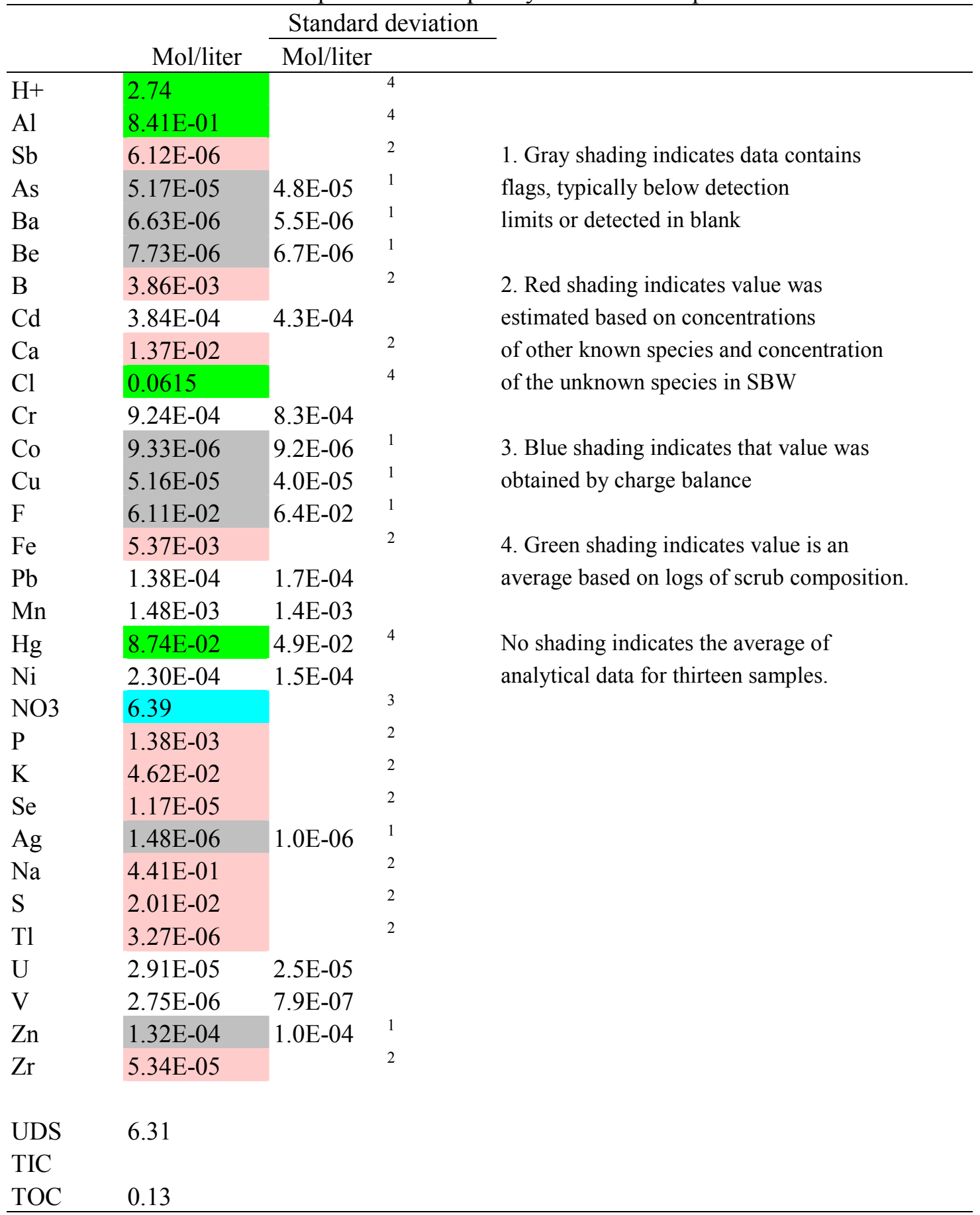


2.4.2.11 CPP-601/627/640 Deactivation Waste. Table 15 shows the composition of deactivation wastes from CPP-601, CPP-627 and CPP-640. Concentrations are taken from Reference 12 and are averages of from 4 to 26 data points, depending on the chemical specie.

Table 15. CPP-601/627/640 Deactivation Waste Composition.




2.4.2.12 Vault Flush. The composition of vault flush waste, after concentration by a factor of 40, was assumed equal to the composition of SBW.

\subsubsection{Composition of Combined Newly Generated Waste}

Tables 16-18 show the compositions of combined wastes generated from 2003-5 and 2006-11. Table 16 shows the composition of all wastes streams combined. This composition is recommended for mass balances for treatment alternatives that do not recycle nitric acid, i.e., the CsIX alternative. Table 17 shows the composition of all wastes excluding LET\&D bottoms, representing the option to recycle nitric acid in a treatment alternative. Table 18 shows compositions of wastes, excluding LET\&D bottoms, and based on removing additional acid by adding water during evaporation. The composition in Table 18 should be used for treatment alternatives that use large volumes of nitric acid.

Table 16. Estimated combined generated waste (including LET\&D bottoms).

\begin{tabular}{|c|c|c|c|c|}
\hline & $\begin{array}{c}\text { Combined Waste } \\
2003-2005 \\
\text { NWCF/MACT }\end{array}$ & $\begin{array}{c}\text { Combined Waste } \\
\text { 2003-2005 } \\
\text { Other Alternatives }\end{array}$ & $\begin{array}{c}\text { Combined Waste } \\
\text { 2006-2011 } \\
\text { NWCF/MACT }\end{array}$ & $\begin{array}{c}\text { Combined Waste } \\
\text { 2006-2011 } \\
\text { Other Alternatives }\end{array}$ \\
\hline \multirow[t]{2}{*}{ Gallons } & 57,500 & 52,000 & 92,000 & 66,400 \\
\hline & Mol/liter & Mol/liter & Mol/liter & Mol/liter \\
\hline$\overline{\mathrm{H}+}$ & $4.29 \mathrm{E}+00$ & $3.78 \mathrm{E}+00$ & $4.91 \mathrm{E}+00$ & $4.19 \mathrm{E}+00$ \\
\hline $\mathrm{Al}$ & $2.06 \mathrm{E}-01$ & $9.42 \mathrm{E}-02$ & $1.73 \mathrm{E}-01$ & $1.57 \mathrm{E}-01$ \\
\hline $\mathrm{Sb}$ & $1.30 \mathrm{E}-05$ & 7.49E-06 & $1.55 \mathrm{E}-05$ & $1.30 \mathrm{E}-05$ \\
\hline As & $5.44 \mathrm{E}-05$ & $1.23 \mathrm{E}-05$ & $4.30 \mathrm{E}-05$ & $4.36 \mathrm{E}-05$ \\
\hline $\mathrm{Ba}$ & $3.28 \mathrm{E}-05$ & $1.70 \mathrm{E}-05$ & $2.95 \mathrm{E}-05$ & $2.78 \mathrm{E}-05$ \\
\hline $\mathrm{Be}$ & $2.82 \mathrm{E}-06$ & 2.07E-06 & $2.84 \mathrm{E}-06$ & 2.94E-06 \\
\hline B & $5.53 \mathrm{E}-03$ & $1.73 \mathrm{E}-03$ & $4.85 \mathrm{E}-03$ & $4.76 \mathrm{E}-03$ \\
\hline $\mathrm{Cd}$ & $1.08 \mathrm{E}-03$ & $1.44 \mathrm{E}-04$ & $6.36 \mathrm{E}-04$ & 8.33E-04 \\
\hline $\mathrm{Ca}$ & $1.71 \mathrm{E}-02$ & $1.22 \mathrm{E}-02$ & $1.61 \mathrm{E}-02$ & $1.48 \mathrm{E}-02$ \\
\hline $\mathrm{Cl}$ & $1.23 \mathrm{E}-02$ & $7.21 \mathrm{E}-03$ & $1.03 \mathrm{E}-02$ & 1.17E-02 \\
\hline $\mathrm{Cr}$ & $3.67 \mathrm{E}-03$ & $3.51 \mathrm{E}-03$ & $3.35 \mathrm{E}-03$ & $4.42 \mathrm{E}-03$ \\
\hline Co & $4.65 \mathrm{E}-05$ & 2.79E-04 & $3.95 \mathrm{E}-05$ & $4.60 \mathrm{E}-05$ \\
\hline $\mathrm{Cu}$ & $2.57 \mathrm{E}-04$ & $8.77 \mathrm{E}-05$ & $1.98 \mathrm{E}-04$ & $2.27 \mathrm{E}-04$ \\
\hline $\mathrm{F}$ & $3.86 \mathrm{E}-02$ & $2.64 \mathrm{E}-02$ & $3.08 \mathrm{E}-02$ & $3.76 \mathrm{E}-02$ \\
\hline $\mathrm{Fe}$ & $6.95 \mathrm{E}-03$ & $6.67 \mathrm{E}-03$ & $6.33 \mathrm{E}-03$ & $6.08 \mathrm{E}-03$ \\
\hline $\mathrm{Pb}$ & $5.20 \mathrm{E}-04$ & $1.48 \mathrm{E}-03$ & 3.19E-04 & $4.05 \mathrm{E}-04$ \\
\hline $\mathrm{Mn}$ & $2.08 \mathrm{E}-02$ & $1.69 \mathrm{E}-02$ & $1.72 \mathrm{E}-02$ & $2.38 \mathrm{E}-02$ \\
\hline $\mathrm{Hg}$ & $3.00 \mathrm{E}-03$ & $2.62 \mathrm{E}-03$ & $4.30 \mathrm{E}-03$ & $1.89 \mathrm{E}-03$ \\
\hline $\mathrm{Ni}$ & $1.09 \mathrm{E}-03$ & 3.99E-04 & 8.29E-04 & $9.67 \mathrm{E}-04$ \\
\hline NO3 & $7.46 \mathrm{E}+00$ & $7.69 \mathrm{E}+00$ & $7.70 \mathrm{E}+00$ & $7.52 \mathrm{E}+00$ \\
\hline $\mathrm{P}$ & $2.30 \mathrm{E}-03$ & $7.85 \mathrm{E}-04$ & $2.05 \mathrm{E}-03$ & $1.83 \mathrm{E}-03$ \\
\hline $\mathrm{K}$ & $3.80 \mathrm{E}-01$ & $1.74 \mathrm{E}+00$ & $3.33 \mathrm{E}-01$ & $4.45 \mathrm{E}-01$ \\
\hline $\mathrm{Se}$ & 1.49E-05 & $5.65 \mathrm{E}-06$ & $1.80 \mathrm{E}-05$ & $1.21 \mathrm{E}-05$ \\
\hline $\mathrm{Ag}$ & 4.77E-06 & $1.86 \mathrm{E}-06$ & $5.06 \mathrm{E}-06$ & $4.21 \mathrm{E}-06$ \\
\hline $\mathrm{Na}$ & $1.92 \mathrm{E}+00$ & $1.54 \mathrm{E}+00$ & $1.71 \mathrm{E}+00$ & $2.17 \mathrm{E}+00$ \\
\hline $\mathrm{S}$ & $1.84 \mathrm{E}-02$ & 7.79E-03 & $1.91 \mathrm{E}-02$ & $1.67 \mathrm{E}-02$ \\
\hline $\mathrm{Tl}$ & $5.78 \mathrm{E}-06$ & $1.83 \mathrm{E}-06$ & $7.62 \mathrm{E}-06$ & 4.74E-06 \\
\hline $\mathrm{U}$ & $1.06 \mathrm{E}-04$ & $4.88 \mathrm{E}-02$ & $6.59 \mathrm{E}-05$ & $8.52 \mathrm{E}-05$ \\
\hline V & $8.96 \mathrm{E}-05$ & $1.65 \mathrm{E}-05$ & $5.83 \mathrm{E}-05$ & 7.30E-05 \\
\hline $\mathrm{Zn}$ & $5.32 \mathrm{E}-04$ & 2.37E-04 & $5.25 \mathrm{E}-04$ & $5.00 \mathrm{E}-04$ \\
\hline \multirow[t]{2}{*}{$\mathrm{Zr}$} & $2.43 \mathrm{E}-03$ & $1.62 \mathrm{E}-04$ & $1.42 \mathrm{E}-03$ & $1.69 \mathrm{E}-03$ \\
\hline & $\mathrm{g} /$ liter & $\mathrm{g} /$ liter & $\mathrm{g} /$ liter & $\mathrm{g} /$ liter \\
\hline UDS & $3.62 \mathrm{E}+00$ & $3.08 \mathrm{E}+00$ & $3.27 \mathrm{E}+00$ & $3.37 \mathrm{E}+00$ \\
\hline TIC & $1.38 \mathrm{E}-01$ & $1.32 \mathrm{E}-01$ & $3.18 \mathrm{E}-01$ & $1.67 \mathrm{E}-01$ \\
\hline TOC & $4.27 \mathrm{E}+00$ & $4.00 \mathrm{E}+00$ & $3.14 \mathrm{E}+00$ & $4.78 \mathrm{E}+00$ \\
\hline
\end{tabular}


Table 17. Estimated combined generated waste (excluding LET\&D bottoms).

\begin{tabular}{|c|c|c|c|c|}
\hline & $\begin{array}{l}\text { Combined Waste } \\
2003-2005 \\
\text { NWCF/MACT }\end{array}$ & $\begin{array}{l}\text { Combined Waste } \\
\text { 2003-2005 } \\
\text { Other Alternatives }\end{array}$ & $\begin{array}{l}\text { Combined Waste } \\
\text { 2006-2011 } \\
\text { NWCF/MACT }\end{array}$ & $\begin{array}{l}\text { Combined Waste } \\
\text { 2006-2011 } \\
\text { Other Alternatives }\end{array}$ \\
\hline \multirow{2}{*}{ Gallons } & 49,600 & 45,200 & 79,300 & 55,700 \\
\hline & $\mathrm{Mol} /$ liter & $\mathrm{Mol} /$ liter & $\mathrm{Mol} /$ liter & $\mathrm{Mol} /$ liter \\
\hline $\mathrm{H}+$ & $3.05 \mathrm{E}+00$ & $3.08 \mathrm{E}+00$ & $3.76 \mathrm{E}+00$ & $2.69 \mathrm{E}+00$ \\
\hline $\mathrm{Al}$ & $2.30 \mathrm{E}-01$ & $2.45 \mathrm{E}-01$ & $1.92 \mathrm{E}-01$ & $1.77 \mathrm{E}-01$ \\
\hline $\mathrm{Sb}$ & 1.49E-05 & $1.51 \mathrm{E}-05$ & $1.79 \mathrm{E}-05$ & $1.54 \mathrm{E}-05$ \\
\hline As & $6.29 \mathrm{E}-05$ & $6.73 \mathrm{E}-05$ & 4.97E-05 & $5.17 \mathrm{E}-05$ \\
\hline $\mathrm{Ba}$ & 3.79E-05 & $3.93 \mathrm{E}-05$ & $3.41 \mathrm{E}-05$ & $3.29 \mathrm{E}-05$ \\
\hline $\mathrm{Be}$ & $3.13 \mathrm{E}-06$ & $3.13 \mathrm{E}-06$ & $3.16 \mathrm{E}-06$ & $3.33 \mathrm{E}-06$ \\
\hline B & $6.38 \mathrm{E}-03$ & $6.73 \mathrm{E}-03$ & $5.59 \mathrm{E}-03$ & $5.63 \mathrm{E}-03$ \\
\hline $\mathrm{Cd}$ & $1.25 \mathrm{E}-03$ & $1.36 \mathrm{E}-03$ & $7.38 \mathrm{E}-04$ & $9.92 \mathrm{E}-04$ \\
\hline $\mathrm{Ca}$ & $1.97 \mathrm{E}-02$ & $2.07 \mathrm{E}-02$ & $1.86 \mathrm{E}-02$ & $1.75 \mathrm{E}-02$ \\
\hline $\mathrm{Cl}$ & $1.32 \mathrm{E}-02$ & $1.37 \mathrm{E}-02$ & $1.09 \mathrm{E}-02$ & $1.26 \mathrm{E}-02$ \\
\hline $\mathrm{Cr}$ & $3.98 \mathrm{E}-03$ & $3.78 \mathrm{E}-03$ & $3.61 \mathrm{E}-03$ & $4.94 \mathrm{E}-03$ \\
\hline Co & $2.60 \mathrm{E}-05$ & $2.78 \mathrm{E}-05$ & $1.77 \mathrm{E}-05$ & $2.14 \mathrm{E}-05$ \\
\hline $\mathrm{Cu}$ & $2.85 \mathrm{E}-04$ & $3.00 \mathrm{E}-04$ & $2.16 \mathrm{E}-04$ & $2.54 \mathrm{E}-04$ \\
\hline $\mathrm{F}$ & $4.36 \mathrm{E}-02$ & $4.45 \mathrm{E}-02$ & $3.46 \mathrm{E}-02$ & $4.35 \mathrm{E}-02$ \\
\hline $\mathrm{Fe}$ & $8.01 \mathrm{E}-03$ & $8.40 \mathrm{E}-03$ & 7.30E-03 & 7.19E-03 \\
\hline $\mathrm{Pb}$ & $6.03 \mathrm{E}-04$ & $6.51 \mathrm{E}-04$ & $3.70 \mathrm{E}-04$ & $4.82 \mathrm{E}-04$ \\
\hline $\mathrm{Mn}$ & $2.41 \mathrm{E}-02$ & $2.34 \mathrm{E}-02$ & $2.00 \mathrm{E}-02$ & $2.83 \mathrm{E}-02$ \\
\hline $\mathrm{Hg}$ & $3.44 \mathrm{E}-03$ & $3.76 \mathrm{E}-03$ & $4.96 \mathrm{E}-03$ & $2.21 \mathrm{E}-03$ \\
\hline $\mathrm{Ni}$ & $9.58 \mathrm{E}-04$ & $1.03 \mathrm{E}-03$ & $6.51 \mathrm{E}-04$ & $7.81 \mathrm{E}-04$ \\
\hline NO3 & $6.69 \mathrm{E}+00$ & $6.70 \mathrm{E}+00$ & $6.97 \mathrm{E}+00$ & $6.61 \mathrm{E}+00$ \\
\hline $\mathrm{P}$ & $2.66 \mathrm{E}-03$ & $2.82 \mathrm{E}-03$ & $2.36 \mathrm{E}-03$ & $2.16 \mathrm{E}-03$ \\
\hline K & $4.40 \mathrm{E}-01$ & $4.23 \mathrm{E}-01$ & $3.86 \mathrm{E}-01$ & $5.30 \mathrm{E}-01$ \\
\hline $\mathrm{Se}$ & $1.71 \mathrm{E}-05$ & $1.80 \mathrm{E}-05$ & $2.07 \mathrm{E}-05$ & $1.41 \mathrm{E}-05$ \\
\hline $\mathrm{Ag}$ & $5.51 \mathrm{E}-06$ & $5.75 \mathrm{E}-06$ & $5.84 \mathrm{E}-06$ & $4.98 \mathrm{E}-06$ \\
\hline $\mathrm{Na}$ & $2.23 \mathrm{E}+00$ & $2.17 \mathrm{E}+00$ & $1.98 \mathrm{E}+00$ & $2.59 \mathrm{E}+00$ \\
\hline S & $2.12 \mathrm{E}-02$ & $2.20 \mathrm{E}-02$ & $2.20 \mathrm{E}-02$ & $1.97 \mathrm{E}-02$ \\
\hline $\mathrm{T} 1$ & $6.61 \mathrm{E}-06$ & $7.00 \mathrm{E}-06$ & $8.76 \mathrm{E}-06$ & $5.53 \mathrm{E}-06$ \\
\hline $\mathrm{U}$ & $1.23 \mathrm{E}-04$ & $1.31 \mathrm{E}-04$ & $7.65 \mathrm{E}-05$ & $1.01 \mathrm{E}-04$ \\
\hline V & $1.04 \mathrm{E}-04$ & $1.11 \mathrm{E}-04$ & $6.74 \mathrm{E}-05$ & $8.66 \mathrm{E}-05$ \\
\hline $\mathrm{Zn}$ & $6.15 \mathrm{E}-04$ & $6.34 \mathrm{E}-04$ & $6.07 \mathrm{E}-04$ & $5.92 \mathrm{E}-04$ \\
\hline \multirow[t]{2}{*}{$\mathrm{Zr}$} & $2.82 \mathrm{E}-03$ & 3.09E-03 & $1.65 \mathrm{E}-03$ & $2.02 \mathrm{E}-03$ \\
\hline & $\mathrm{g} /$ liter & $\mathrm{g} /$ liter & $\mathrm{g} /$ liter & $\mathrm{g} /$ liter \\
\hline UDS & $4.20 \mathrm{E}+00$ & $4.20 \mathrm{E}+00$ & $3.79 \mathrm{E}+00$ & $4.01 \mathrm{E}+00$ \\
\hline TIC & $1.53 \mathrm{E}-01$ & $1.45 \mathrm{E}-01$ & $3.62 \mathrm{E}-01$ & $1.91 \mathrm{E}-01$ \\
\hline \multirow[t]{2}{*}{ TOC } & $4.95 \mathrm{E}+00$ & $4.76 \mathrm{E}+00$ & $3.65 \mathrm{E}+00$ & $5.69 \mathrm{E}+00$ \\
\hline & $\begin{array}{l}\text { gallons } \\
7,900\end{array}$ & $\begin{array}{l}\text { gallons } \\
6,800\end{array}$ & $\begin{array}{l}\text { gallons } \\
12,700\end{array}$ & $\begin{array}{l}\text { gallons } \\
10,700\end{array}$ \\
\hline
\end{tabular}


Table 18. Estimated combined generated waste (excluding LET\&D bottoms, additional acid removal).

\begin{tabular}{|c|c|c|c|c|}
\hline & $\begin{array}{l}\text { Combined Waste } \\
2003-2005 \\
\text { NWCF/MACT }\end{array}$ & $\begin{array}{l}\text { Combined Waste } \\
\text { 2003-2005 } \\
\text { Other Alternatives }\end{array}$ & $\begin{array}{l}\text { Combined Waste } \\
\text { 2006-2011 } \\
\text { NWCF/MACT }\end{array}$ & $\begin{array}{l}\text { Combined Waste } \\
\text { 2006-2011 } \\
\text { Other Alternatives }\end{array}$ \\
\hline \multirow{2}{*}{ Gallons } & 44,400 & 39,900 & 69,400 & 44,000 \\
\hline & Mol/liter & Mol/liter & Mol/liter & Mol/liter \\
\hline $\mathrm{H}+$ & $1.86 \mathrm{E}+00$ & $1.99 \mathrm{E}+00$ & $2.92 \mathrm{E}+00$ & $1.07 \mathrm{E}+00$ \\
\hline $\mathrm{Al}$ & $2.65 \mathrm{E}-01$ & $2.83 \mathrm{E}-01$ & $2.22 \mathrm{E}-01$ & $2.28 \mathrm{E}-01$ \\
\hline $\mathrm{Sb}$ & $1.81 \mathrm{E}-05$ & $1.81 \mathrm{E}-05$ & $2.09 \mathrm{E}-05$ & $2.00 \mathrm{E}-05$ \\
\hline As & $7.21 \mathrm{E}-05$ & $7.75 \mathrm{E}-05$ & $5.73 \mathrm{E}-05$ & $6.58 \mathrm{E}-05$ \\
\hline $\mathrm{Ba}$ & $4.48 \mathrm{E}-05$ & $4.62 \mathrm{E}-05$ & $3.98 \mathrm{E}-05$ & $4.26 \mathrm{E}-05$ \\
\hline $\mathrm{Be}$ & $3.84 \mathrm{E}-06$ & $3.79 \mathrm{E}-06$ & $3.71 \mathrm{E}-06$ & $4.37 \mathrm{E}-06$ \\
\hline B & $7.43 \mathrm{E}-03$ & $7.83 \mathrm{E}-03$ & $6.48 \mathrm{E}-03$ & $7.28 \mathrm{E}-03$ \\
\hline $\mathrm{Cd}$ & $1.42 \mathrm{E}-03$ & $1.55 \mathrm{E}-03$ & $8.50 \mathrm{E}-04$ & $1.26 \mathrm{E}-03$ \\
\hline $\mathrm{Ca}$ & $2.31 \mathrm{E}-02$ & $2.41 \mathrm{E}-02$ & $2.15 \mathrm{E}-02$ & $2.28 \mathrm{E}-02$ \\
\hline $\mathrm{Cl}$ & $1.51 \mathrm{E}-02$ & $1.56 \mathrm{E}-02$ & $1.21 \mathrm{E}-02$ & $1.51 \mathrm{E}-02$ \\
\hline $\mathrm{Cr}$ & $5.10 \mathrm{E}-03$ & $4.75 \mathrm{E}-03$ & 4.32E-03 & $6.45 \mathrm{E}-03$ \\
\hline Co & $2.97 \mathrm{E}-05$ & $3.20 \mathrm{E}-05$ & $2.04 \mathrm{E}-05$ & $2.73 \mathrm{E}-05$ \\
\hline $\mathrm{Cu}$ & $3.32 \mathrm{E}-04$ & $3.49 \mathrm{E}-04$ & $2.51 \mathrm{E}-04$ & $3.28 \mathrm{E}-04$ \\
\hline $\mathrm{F}$ & 4.61E-02 & 4.72E-02 & $3.57 \mathrm{E}-02$ & $4.75 \mathrm{E}-02$ \\
\hline $\mathrm{Fe}$ & $9.37 \mathrm{E}-03$ & $9.81 \mathrm{E}-03$ & $8.47 \mathrm{E}-03$ & $9.27 \mathrm{E}-03$ \\
\hline $\mathrm{Pb}$ & $6.86 \mathrm{E}-04$ & $7.45 \mathrm{E}-04$ & $4.26 \mathrm{E}-04$ & $6.15 \mathrm{E}-04$ \\
\hline $\mathrm{Mn}$ & 3.03E-02 & $2.89 \mathrm{E}-02$ & $2.38 \mathrm{E}-02$ & $3.69 \mathrm{E}-02$ \\
\hline $\mathrm{Hg}$ & $3.80 \mathrm{E}-03$ & 4.22E-03 & $5.62 \mathrm{E}-03$ & $2.73 \mathrm{E}-03$ \\
\hline $\mathrm{Ni}$ & $1.09 \mathrm{E}-03$ & $1.18 \mathrm{E}-03$ & $7.51 \mathrm{E}-04$ & $1.00 \mathrm{E}-03$ \\
\hline NO3 & $6.35 \mathrm{E}+00$ & $6.39 \mathrm{E}+00$ & $6.71 \mathrm{E}+00$ & $6.18 \mathrm{E}+00$ \\
\hline $\mathrm{P}$ & $3.08 \mathrm{E}-03$ & $3.27 \mathrm{E}-03$ & $2.73 \mathrm{E}-03$ & 2.79E-03 \\
\hline K & $5.58 \mathrm{E}-01$ & $5.27 \mathrm{E}-01$ & $4.61 \mathrm{E}-01$ & $6.91 \mathrm{E}-01$ \\
\hline $\mathrm{Se}$ & $1.98 \mathrm{E}-05$ & $2.09 \mathrm{E}-05$ & $2.38 \mathrm{E}-05$ & $1.79 \mathrm{E}-05$ \\
\hline $\mathrm{Ag}$ & $6.48 \mathrm{E}-06$ & $6.74 \mathrm{E}-06$ & $6.77 \mathrm{E}-06$ & $6.41 \mathrm{E}-06$ \\
\hline $\mathrm{Na}$ & $2.79 \mathrm{E}+00$ & $2.67 \mathrm{E}+00$ & $2.35 \mathrm{E}+00$ & $3.37 \mathrm{E}+00$ \\
\hline S & $2.50 \mathrm{E}-02$ & $2.59 \mathrm{E}-02$ & $2.56 \mathrm{E}-02$ & $2.56 \mathrm{E}-02$ \\
\hline $\mathrm{Tl}$ & $7.65 \mathrm{E}-06$ & $8.12 \mathrm{E}-06$ & $1.01 \mathrm{E}-05$ & $7.00 \mathrm{E}-06$ \\
\hline $\mathrm{U}$ & $1.41 \mathrm{E}-04$ & $1.51 \mathrm{E}-04$ & $8.83 \mathrm{E}-05$ & $1.29 \mathrm{E}-04$ \\
\hline V & $1.19 \mathrm{E}-04$ & $1.28 \mathrm{E}-04$ & 7.79E-05 & $1.11 \mathrm{E}-04$ \\
\hline $\mathrm{Zn}$ & $7.32 \mathrm{E}-04$ & 7.49E-04 & 7.07E-04 & 7.70E-04 \\
\hline $\mathrm{Zr}$ & $3.15 \mathrm{E}-03$ & $3.50 \mathrm{E}-03$ & $1.89 \mathrm{E}-03$ & $2.55 \mathrm{E}-03$ \\
\hline UDS & $5.15 \mathrm{E}+00$ & $5.08 \mathrm{E}+00$ & $4.47 \mathrm{E}+00$ & $5.29 \mathrm{E}+00$ \\
\hline TIC & $1.96 \mathrm{E}-01$ & $1.82 \mathrm{E}-01$ & 4.19E-01 & $1.76 \mathrm{E}-01$ \\
\hline \multirow[t]{2}{*}{ TOC } & $5.88 \mathrm{E}+00$ & $5.50 \mathrm{E}+00$ & $4.35 \mathrm{E}+00$ & $6.37 \mathrm{E}+00$ \\
\hline & gallons & gallons & gallons & gallons \\
\hline LET\&D btms & 13,600 & 11,700 & 20,500 & 19,300 \\
\hline
\end{tabular}

\subsection{Tank WM-187 Liquid Composition}

Tank WM-187 has been and will continue to be used as a collection tank for solids and dilute wastes until the time of SBW treatment. Table 19 shows the estimated composition of the liquid that will be in Tank WM-187 at the time of SBW treatment. 
Table 19. Estimated liquid composition of Tank WM-187 at time of SBW treatment.

\begin{tabular}{|c|c|c|c|c|c|}
\hline & $\mathrm{mol} /$ liter & & $\mathrm{mol} /$ liter & & i/liter \\
\hline $\mathrm{H}+$ & $2.29 \mathrm{E}-01$ & $\mathrm{Sm}$ & $5.87 \mathrm{E}-07$ & $\mathrm{Cm}-246$ & $2.03 \mathrm{E}-12$ \\
\hline $\mathrm{Al}$ & $3.58 \mathrm{E}-02$ & $\mathrm{Se}$ & $1.28 \mathrm{E}-06$ & $\mathrm{H}-3$ & $2.87 \mathrm{E}-06$ \\
\hline $\mathrm{Am}$ & $6.23 \mathrm{E}-09$ & $\mathrm{Ag}$ & 4.34E-06 & Be-10 & $3.09 \mathrm{E}-13$ \\
\hline $\mathrm{Sb}$ & 4.35E-08 & $\mathrm{Na}$ & $1.13 \mathrm{E}-01$ & C-14 & $6.62 \mathrm{E}-12$ \\
\hline As & $3.85 \mathrm{E}-06$ & $\mathrm{Sr}$ & $1.53 \mathrm{E}-06$ & Se-79 & $4.50 \mathrm{E}-08$ \\
\hline $\mathrm{Ba}$ & $3.85 \mathrm{E}-06$ & $\mathrm{SO} 4$ & $4.67 \mathrm{E}-03$ & $\mathrm{Rb}-87$ & $3.02 \mathrm{E}-12$ \\
\hline $\mathrm{Be}$ & 7.09E-08 & Tc & $6.28 \mathrm{E}-07$ & Sr-90 & $4.89 \mathrm{E}-03$ \\
\hline B & $2.07 \mathrm{E}-03$ & $\mathrm{Te}$ & $3.08 \mathrm{E}-07$ & Y-90 & $5.30 \mathrm{E}-03$ \\
\hline $\mathrm{Br}$ & $3.26 \mathrm{E}-08$ & $\mathrm{~Tb}$ & $2.26 \mathrm{E}-10$ & Zr-93 & $2.28 \mathrm{E}-07$ \\
\hline $\mathrm{Cd}$ & $5.52 \mathrm{E}-04$ & $\mathrm{Tl}$ & 4.00E-08 & $\mathrm{Nb}-93 \mathrm{~m}$ & $1.76 \mathrm{E}-07$ \\
\hline $\mathrm{Ca}$ & $5.83 \mathrm{E}-03$ & $\mathrm{Sn}$ & $1.13 \mathrm{E}-07$ & Nb-94 & $1.17 \mathrm{E}-07$ \\
\hline $\mathrm{C}$ & $3.77 \mathrm{E}-07$ & $\mathrm{U}$ & $4.16 \mathrm{E}-05$ & Zr-95 & $2.96 \mathrm{E}-06$ \\
\hline $\mathrm{Ce}$ & $1.78 \mathrm{E}-06$ & $\mathrm{~V}$ & $1.31 \mathrm{E}-07$ & Tc-98 & $2.66 \mathrm{E}-13$ \\
\hline Cs & $1.94 \mathrm{E}-06$ & $\mathrm{Y}$ & 7.32E-07 & Tc-99 & $1.15 \mathrm{E}-06$ \\
\hline $\mathrm{Cl}$ & $1.58 \mathrm{E}-03$ & $\mathrm{Zn}$ & $1.10 \mathrm{E}-05$ & Ru-106 & $6.17 \mathrm{E}-07$ \\
\hline $\mathrm{Cr}$ & 4.41E-04 & $\mathrm{Zr}$ & $8.38 \mathrm{E}-04$ & Pd-107 & $1.70 \mathrm{E}-09$ \\
\hline Co & $8.50 \mathrm{E}-07$ & & & Cd-113m & $3.42 \mathrm{E}-07$ \\
\hline $\mathrm{Cu}$ & $1.11 \mathrm{E}-05$ & & Ci/liter & In-115 & $1.04 \mathrm{E}-17$ \\
\hline $\mathrm{Eu}$ & $5.40 \mathrm{E}-08$ & Ra-226 & $8.45 \mathrm{E}-13$ & Sn-121m & $6.89 \mathrm{E}-09$ \\
\hline $\mathrm{F}$ & $1.11 \mathrm{E}-02$ & Th-228 & $3.30 \mathrm{E}-10$ & Sn-126 & 4.24E-08 \\
\hline $\mathrm{Gd}$ & $6.81 \mathrm{E}-06$ & Th-230 & $8.48 \mathrm{E}-11$ & Sb-125 & $3.46 \mathrm{E}-06$ \\
\hline $\mathrm{Ge}$ & $9.39 \mathrm{E}-10$ & Th-232 & $7.30 \mathrm{E}-17$ & Тe-123 & $3.95 \mathrm{E}-20$ \\
\hline In & $1.46 \mathrm{E}-08$ & $\mathrm{~Pa}-231$ & $9.21 \mathrm{E}-12$ & $\mathrm{Te}-125 \mathrm{~m}$ & $3.25 \mathrm{E}-07$ \\
\hline I & $2.71 \mathrm{E}-07$ & $\mathrm{~Pa}-233$ & $3.02 \mathrm{E}-07$ & I-129 & $2.99 \mathrm{E}-09$ \\
\hline $\mathrm{Fe}$ & $1.89 \mathrm{E}-03$ & U-232 & $2.05 \mathrm{E}-10$ & Cs-134 & $6.21 \mathrm{E}-06$ \\
\hline $\mathrm{La}$ & $9.81 \mathrm{E}-07$ & U-233 & $8.25 \mathrm{E}-12$ & Cs-135 & $8.86 \mathrm{E}-08$ \\
\hline $\mathrm{Pb}$ & $1.22 \mathrm{E}-04$ & U-234 & 4.34E-08 & Cs-137 & $5.20 \mathrm{E}-03$ \\
\hline $\mathrm{Li}$ & $2.43 \mathrm{E}-06$ & U-235 & $1.78 \mathrm{E}-09$ & Ba- $137 \mathrm{~m}$ & $4.92 \mathrm{E}-03$ \\
\hline $\mathrm{Mg}$ & $1.67 \mathrm{E}-04$ & U-236 & $1.82 \mathrm{E}-09$ & La-138 & $1.97 \mathrm{E}-17$ \\
\hline $\mathrm{Mn}$ & $1.55 \mathrm{E}-03$ & U-238 & $3.15 \mathrm{E}-09$ & $\mathrm{Ce}-142$ & $3.08 \mathrm{E}-12$ \\
\hline $\mathrm{Hg}$ & $1.22 \mathrm{E}-04$ & $\mathrm{~Np}-236$ & $3.16 \mathrm{E}-13$ & $\mathrm{Ce}-144$ & $3.42 \mathrm{E}-07$ \\
\hline Mo & $2.60 \mathrm{E}-06$ & Np-237 & $2.03 \mathrm{E}-07$ & Nd-144 & $1.66 \mathrm{E}-16$ \\
\hline $\mathrm{Nd}$ & $3.17 \mathrm{E}-06$ & Pu-236 & $2.82 \mathrm{E}-10$ & Pm-146 & $5.25 \mathrm{E}-09$ \\
\hline $\mathrm{Np}$ & $1.81 \mathrm{E}-06$ & Pu-238 & $8.01 \mathrm{E}-05$ & Pm-147 & $1.76 \mathrm{E}-05$ \\
\hline $\mathrm{Ni}$ & $2.07 \mathrm{E}-04$ & Pu-239 & 4.19E-06 & Sm-146 & $2.84 \mathrm{E}-14$ \\
\hline $\mathrm{Nb}$ & 4.66E-07 & $\mathrm{Pu}-240$ & $9.08 \mathrm{E}-07$ & Sm-147 & $7.60 \mathrm{E}-13$ \\
\hline NO3 & 4.57E-01 & $\mathrm{Pu}-241$ & $6.58 \mathrm{E}-05$ & Sm-148 & $3.90 \mathrm{E}-18$ \\
\hline $\mathrm{Pd}$ & $3.74 \mathrm{E}-07$ & $\mathrm{Pu}-242$ & $1.36 \mathrm{E}-09$ & Sm-149 & $3.46 \mathrm{E}-19$ \\
\hline PO4 & $1.11 \mathrm{E}-04$ & $\mathrm{Pu}-244$ & $6.98 \mathrm{E}-17$ & Sm-151 & $3.46 \mathrm{E}-05$ \\
\hline $\mathrm{Pu}$ & $5.70 \mathrm{E}-07$ & Am-241 & $6.11 \mathrm{E}-06$ & Eu-152 & $2.59 \mathrm{E}-07$ \\
\hline $\mathrm{K}$ & $1.58 \mathrm{E}-02$ & $\mathrm{Am}-242 \mathrm{~m}$ & $1.57 \mathrm{E}-09$ & Eu-154 & $2.68 \mathrm{E}-05$ \\
\hline $\operatorname{Pr}$ & $8.92 \mathrm{E}-07$ & Am-243 & $2.21 \mathrm{E}-09$ & Eu-155 & 7.44E-06 \\
\hline $\mathrm{Pm}$ & $1.31 \mathrm{E}-10$ & $\mathrm{Cm}-242$ & $1.29 \mathrm{E}-09$ & Gd-152 & $1.47 \mathrm{E}-19$ \\
\hline $\mathrm{Rh}$ & $3.85 \mathrm{E}-07$ & $\mathrm{Cm}-243$ & $2.93 \mathrm{E}-09$ & Но- $166 \mathrm{~m}$ & $4.75 \mathrm{E}-12$ \\
\hline $\mathrm{Rb}$ & $5.93 \mathrm{E}-07$ & $\mathrm{Cm}-244$ & $1.82 \mathrm{E}-07$ & Co-60 & $7.00 \mathrm{E}-06$ \\
\hline $\mathrm{Ru}$ & $2.35 \mathrm{E}-06$ & $\mathrm{Cm}-245$ & $3.08 \mathrm{E}-11$ & $\mathrm{Ni}-63$ & $6.94 \mathrm{E}-06$ \\
\hline
\end{tabular}




\subsection{Summary of Liquid Waste Compositions}

This section presents feed compositions recommended for use in SBW Treatment Facility design and development studies. For alternatives in which solids are processed separately from the liquid, the feed compositions are equivalent to the tank waste compositions, diluted by steam used to jet waste out of the tanks. For alternatives in which solids are co-processed with liquids, transfers between tanks will result in some degree of blending the liquid compositions.

\subsubsection{Tank Waste Compositions}

The compositions of wastes in Tanks WM-180 and WM-189 are not expected to change from theirs present composition and hence are the same for all treatment alternatives. While the waste in Tank WM-188 will change and will not be exactly the same for each treatment alternative, a comparison of WM-188 compositions given in Table 3 shows that the differences in the composition for the different alternatives are negligible. Table 20 presents the composition of liquid waste in Tanks WM-180, WM188, WM-189 and WM-187 at the time of treatment. Table 21 presents a composition of generated waste recommended for use in treatment alternative studies for each of the alternatives.

Concentrations shown in Table 20 and 21 have been adjusted to ensure charge balance and consistency between radionuclide activities and chemical concentrations. Nitrate concentrations were adjusted to obtain charge balance. To check for consistency between radionuclide activities and chemical concentrations, activities of radionuclides were converted to molar concentrations and compared to concentrations measured or estimated for the chemical species. If the sum of the concentrations of all isotopes of an element, converted from activities, was greater than the chemical concentration for that element, the chemical concentration was replaced by that sum. ${ }^{a}$ For example, if the concentration of Americium, as calculated by converting ${ }^{241} \mathrm{Am},{ }^{242 \mathrm{~m}} \mathrm{Am},{ }^{242} \mathrm{Am}$, and ${ }^{243} \mathrm{Am}$ concentrations in curies per liter to moles per liter and summing was greater than the molar concentration of Am reported as a chemical species, then the sum of the isotopes was used as the concentration. With these adjustments, values in Table 20 are consistent with those shown in previous tables of compositions for the individual tanks. Chemical species with concentrations less than $10^{-10} \mathrm{~mol} / \mathrm{liter}$ and isotopes with concentrations less than $10^{-15} \mathrm{~mol} / \mathrm{liter}$ were not included in Tables 20 and 21 .

The entrained solids (often called "UDS" - solids that are carried with liquid transferred out of a tank) concentration shown for WM-180 in Table 20 is based on analysis of a sample taken from the tank in 2000. Christian ${ }^{3}$ reported a value of UDS for an agitated sample of $0.234 \mathrm{~g} /$ liter; the value shown in Table 20 is corrected for steam jet dilution contained in the sample. No comparable measurements are available for Tanks WM-188 or WM-189. The value shown in Table 20 for these two tanks is the average of UDS concentrations measured in samples from five tanks of SBW sampled between 1988 and 1993. The range of UDS in the historical data for these five SBW tanks was $0.17 \mathrm{~g} /$ liter to $5.05 \mathrm{~g} / \mathrm{liter}$. An estimated concentration of settled solids (as if averaged in the entire volume of liquid) is also shown for each tank.

The TOC concentration in WM-189 is based on analysis of the 2002 sample from WM-189. ${ }^{4}$ The TOC concentration for WM-188 was assumed to be the same as for WM-189. The TOC concentration in WM-180 was assumed to be the average of TOC analysis of historical samples from three other tanks.

\footnotetext{
${ }^{a}$ In most cases, the chemical concentration is greater than that of the same species calculated from isotopic concentrations because of nonradioactive isotopes.
} 
Table 20. Composition of tank wastes.

\begin{tabular}{|c|c|c|c|c|}
\hline \multirow{2}{*}{ Gallons } & WM-180 & WM-188 & WM-189 & WM-187 \\
\hline & 276,000 & 285,000 & 280,100 & 88,000 \\
\hline & $\mathrm{mol} /$ liter & $\mathrm{mol} /$ liter & $\mathrm{mol} /$ liter & $\mathrm{mol} /$ liter \\
\hline $\mathrm{H}+$ & $1.12 \mathrm{E}+00$ & $3.02 \mathrm{E}+00$ & $2.90 \mathrm{E}+00$ & $2.29 \mathrm{E}-01$ \\
\hline $\mathrm{Al}$ & $6.06 \mathrm{E}-01$ & $6.98 \mathrm{E}-01$ & $7.12 \mathrm{E}-01$ & $3.58 \mathrm{E}-02$ \\
\hline $\mathrm{Am}$ & 8.57E-08 & $1.03 \mathrm{E}-07$ & 8.92E-08 & 7.43E-09 \\
\hline $\mathrm{Sb}$ & $3.59 \mathrm{E}-08$ & $2.31 \mathrm{E}-06$ & 7.52E-06 & $4.35 \mathrm{E}-08$ \\
\hline As & 4.71E-04 & $1.08 \mathrm{E}-05$ & 2.42E-09 & $3.85 \mathrm{E}-06$ \\
\hline $\mathrm{Ba}$ & $5.17 \mathrm{E}-05$ & $3.10 \mathrm{E}-05$ & $5.62 \mathrm{E}-05$ & $3.85 \mathrm{E}-06$ \\
\hline $\mathrm{Be}$ & 7.33E-06 & $1.22 \mathrm{E}-06$ & $2.02 \mathrm{E}-05$ & $7.09 \mathrm{E}-08$ \\
\hline B & $1.08 \mathrm{E}-02$ & $2.38 \mathrm{E}-02$ & $2.12 \mathrm{E}-02$ & $2.07 \mathrm{E}-03$ \\
\hline $\mathrm{Br}$ & $1.64 \mathrm{E}-07$ & $5.27 \mathrm{E}-07$ & $3.14 \mathrm{E}-07$ & $3.26 \mathrm{E}-08$ \\
\hline $\mathrm{Cd}$ & 7.49E-04 & $5.17 \mathrm{E}-03$ & $3.91 \mathrm{E}-03$ & $5.52 \mathrm{E}-04$ \\
\hline $\mathrm{Ca}$ & $3.85 \mathrm{E}-02$ & $7.98 \mathrm{E}-02$ & $7.31 \mathrm{E}-02$ & $5.83 \mathrm{E}-03$ \\
\hline $\mathrm{C}$ & $1.90 \mathrm{E}-06$ & $6.11 \mathrm{E}-06$ & $3.64 \mathrm{E}-06$ & $3.77 \mathrm{E}-07$ \\
\hline $\mathrm{Ce}$ & $4.46 \mathrm{E}-05$ & $2.98 \mathrm{E}-05$ & $3.51 \mathrm{E}-05$ & $1.78 \mathrm{E}-06$ \\
\hline Cs & 9.97E-06 & $3.18 \mathrm{E}-05$ & $2.68 \mathrm{E}-05$ & $1.94 \mathrm{E}-06$ \\
\hline $\mathrm{Cl}$ & $3.00 \mathrm{E}-02$ & $2.90 \mathrm{E}-02$ & $2.06 \mathrm{E}-02$ & $1.58 \mathrm{E}-03$ \\
\hline $\mathrm{Cr}$ & $3.49 \mathrm{E}-03$ & $6.24 \mathrm{E}-03$ & $5.64 \mathrm{E}-03$ & 4.41E-04 \\
\hline Co & $1.82 \mathrm{E}-05$ & $8.57 \mathrm{E}-06$ & $4.63 \mathrm{E}-05$ & $8.50 \mathrm{E}-07$ \\
\hline $\mathrm{Cu}$ & $6.57 \mathrm{E}-04$ & $1.06 \mathrm{E}-04$ & $9.54 \mathrm{E}-04$ & $1.11 \mathrm{E}-05$ \\
\hline $\mathrm{Cm}$ & $5.11 \mathrm{E}-11$ & $1.64 \mathrm{E}-10$ & $9.78 \mathrm{E}-11$ & $1.02 \mathrm{E}-11$ \\
\hline Dy & $3.38 \mathrm{E}-10$ & 1.09E-09 & $6.46 \mathrm{E}-10$ & $6.71 \mathrm{E}-11$ \\
\hline $\mathrm{Eu}$ & $2.72 \mathrm{E}-07$ & 8.74E-07 & $5.20 \mathrm{E}-07$ & $5.40 \mathrm{E}-08$ \\
\hline $\mathrm{F}$ & 4.24E-02 & $1.18 \mathrm{E}-01$ & $1.37 \mathrm{E}-02$ & $1.11 \mathrm{E}-02$ \\
\hline Gd & $1.67 \mathrm{E}-04$ & $4.81 \mathrm{E}-05$ & $1.35 \mathrm{E}-04$ & $6.81 \mathrm{E}-06$ \\
\hline $\mathrm{Ge}$ & 4.73E-09 & $1.52 \mathrm{E}-08$ & $9.05 \mathrm{E}-09$ & $9.39 \mathrm{E}-10$ \\
\hline In & 7.34E-08 & $2.36 \mathrm{E}-07$ & $1.40 \mathrm{E}-07$ & $1.46 \mathrm{E}-08$ \\
\hline I & $1.36 \mathrm{E}-06$ & $4.38 \mathrm{E}-06$ & $2.61 \mathrm{E}-06$ & $2.71 \mathrm{E}-07$ \\
\hline $\mathrm{Fe}$ & $1.87 \mathrm{E}-02$ & $2.82 \mathrm{E}-02$ & 2.69E-02 & $1.89 \mathrm{E}-03$ \\
\hline $\mathrm{La}$ & 4.94E-06 & $1.59 \mathrm{E}-05$ & $9.45 \mathrm{E}-06$ & $9.81 \mathrm{E}-07$ \\
\hline $\mathrm{Pb}$ & $1.32 \mathrm{E}-03$ & $1.07 \mathrm{E}-03$ & $1.16 \mathrm{E}-03$ & $1.22 \mathrm{E}-04$ \\
\hline $\mathrm{Li}$ & $3.68 \mathrm{E}-04$ & $1.71 \mathrm{E}-05$ & $3.83 \mathrm{E}-04$ & $2.43 \mathrm{E}-06$ \\
\hline $\mathrm{Mg}$ & $1.13 \mathrm{E}-02$ & $7.81 \mathrm{E}-03$ & $2.21 \mathrm{E}-02$ & $1.67 \mathrm{E}-04$ \\
\hline $\mathrm{Mn}$ & $1.33 \mathrm{E}-02$ & $5.20 \mathrm{E}-03$ & $1.95 \mathrm{E}-02$ & $1.55 \mathrm{E}-03$ \\
\hline $\mathrm{Hg}$ & $1.35 \mathrm{E}-03$ & $5.54 \mathrm{E}-03$ & $6.48 \mathrm{E}-03$ & $1.22 \mathrm{E}-04$ \\
\hline Mo & 1.82E-04 & 7.87E-05 & $2.80 \mathrm{E}-04$ & $2.60 \mathrm{E}-06$ \\
\hline $\mathrm{Nd}$ & $1.59 \mathrm{E}-05$ & $5.12 \mathrm{E}-05$ & $3.05 \mathrm{E}-05$ & $3.17 \mathrm{E}-06$ \\
\hline $\mathrm{Np}$ & $9.10 \mathrm{E}-06$ & $2.93 \mathrm{E}-05$ & $1.74 \mathrm{E}-05$ & $1.81 \mathrm{E}-06$ \\
\hline $\mathrm{Ni}$ & $1.44 \mathrm{E}-03$ & $3.17 \mathrm{E}-03$ & 2.32E-03 & 2.07E-04 \\
\hline $\mathrm{Nb}$ & $3.40 \mathrm{E}-08$ & 3.34E-06 & $6.52 \mathrm{E}-08$ & $4.66 \mathrm{E}-07$ \\
\hline NO3 & $5.17 \mathrm{E}+00$ & $7.25 \mathrm{E}+00$ & $7.48 \mathrm{E}+00$ & $4.85 \mathrm{E}-01$ \\
\hline $\mathrm{Pd}$ & 1.89E-06 & $6.06 \mathrm{E}-06$ & $3.61 \mathrm{E}-06$ & $3.74 \mathrm{E}-07$ \\
\hline PO4 & 2.88E-03 & 8.91E-03 & $2.07 \mathrm{E}-03$ & $1.11 \mathrm{E}-04$ \\
\hline $\mathrm{Pu}$ & $5.82 \mathrm{E}-06$ & $6.55 \mathrm{E}-06$ & $3.75 \mathrm{E}-06$ & $3.22 \mathrm{E}-07$ \\
\hline K & $1.84 \mathrm{E}-01$ & 2.39E-01 & $2.25 \mathrm{E}-01$ & $1.58 \mathrm{E}-02$ \\
\hline $\operatorname{Pr}$ & 4.49E-06 & $1.44 \mathrm{E}-05$ & $8.60 \mathrm{E}-06$ & $8.92 \mathrm{E}-07$ \\
\hline Pm & $6.57 \mathrm{E}-10$ & $2.11 \mathrm{E}-09$ & $1.26 \mathrm{E}-09$ & $1.31 \mathrm{E}-10$ \\
\hline $\mathrm{Rh}$ & $1.94 \mathrm{E}-06$ & $6.23 \mathrm{E}-06$ & $3.71 \mathrm{E}-06$ & $3.85 \mathrm{E}-07$ \\
\hline $\mathrm{Rb}$ & $2.98 \mathrm{E}-06$ & $9.59 \mathrm{E}-06$ & $5.71 \mathrm{E}-06$ & $5.93 \mathrm{E}-07$ \\
\hline $\mathrm{Ru}$ & $1.18 \mathrm{E}-04$ & & $1.72 \mathrm{E}-04$ & \\
\hline
\end{tabular}


Table 20 (continued).

\begin{tabular}{|c|c|c|c|c|}
\hline & $\begin{array}{l}\text { WM-180 } \\
\text { mol/liter }\end{array}$ & $\begin{array}{l}\text { WM-188 } \\
\text { mol/liter }\end{array}$ & $\begin{array}{l}\text { WM-189 } \\
\text { mol/liter }\end{array}$ & $\begin{array}{l}\text { WM-187 } \\
\text { mol/liter }\end{array}$ \\
\hline $\mathrm{Sm}$ & $2.95 \mathrm{E}-06$ & $9.49 \mathrm{E}-06$ & $5.65 \mathrm{E}-06$ & $5.87 \mathrm{E}-07$ \\
\hline $\mathrm{Se}$ & $1.04 \mathrm{E}-05$ & $4.30 \mathrm{E}-06$ & $8.24 \mathrm{E}-07$ & $1.28 \mathrm{E}-06$ \\
\hline $\mathrm{Si}$ & $2.80 \mathrm{E}-04$ & $1.77 \mathrm{E}-03$ & $3.08 \mathrm{E}-04$ & $1.77 \mathrm{E}-03$ \\
\hline Ag & 4.43E-06 & $5.89 \mathrm{E}-06$ & $6.54 \mathrm{E}-08$ & $4.34 \mathrm{E}-06$ \\
\hline $\mathrm{Na}$ & $1.98 \mathrm{E}+00$ & $1.75 \mathrm{E}+00$ & $2.04 \mathrm{E}+00$ & $1.13 \mathrm{E}-01$ \\
\hline $\mathrm{Sr}$ & $1.12 \mathrm{E}-04$ & $2.00 \mathrm{E}-05$ & $1.42 \mathrm{E}-04$ & $1.53 \mathrm{E}-06$ \\
\hline $\mathrm{SO} 4$ & $5.17 \mathrm{E}-02$ & 4.74E-02 & $1.07 \mathrm{E}-01$ & $4.67 \mathrm{E}-03$ \\
\hline Tc & $5.59 \mathrm{E}-06$ & $1.05 \mathrm{E}-05$ & 5.94E-06 & $6.88 \mathrm{E}-07$ \\
\hline $\mathrm{Te}$ & $1.55 \mathrm{E}-06$ & 4.99E-06 & 7.26E-06 & $3.08 \mathrm{E}-07$ \\
\hline $\mathrm{Tb}$ & $1.14 \mathrm{E}-09$ & 3.66E-09 & $2.18 \mathrm{E}-09$ & $2.26 \mathrm{E}-10$ \\
\hline $\mathrm{Tl}$ & $1.05 \mathrm{E}-20$ & $1.08 \mathrm{E}-06$ & $2.00 \mathrm{E}-20$ & $4.00 \mathrm{E}-08$ \\
\hline Th & $1.06 \mathrm{E}-10$ & $3.39 \mathrm{E}-10$ & $3.50 \mathrm{E}-05$ & $2.10 \mathrm{E}-11$ \\
\hline $\mathrm{Tm}$ & $2.64 \mathrm{E}-15$ & $8.49 \mathrm{E}-15$ & $5.05 \mathrm{E}-15$ & $5.25 \mathrm{E}-16$ \\
\hline $\mathrm{Sn}$ & $6.33 \mathrm{E}-08$ & $9.14 \mathrm{E}-07$ & $4.14 \mathrm{E}-05$ & $1.13 \mathrm{E}-07$ \\
\hline $\mathrm{Ti}$ & $5.45 \mathrm{E}-05$ & $5.84 \mathrm{E}-05$ & 7.29E-05 & $5.84 \mathrm{E}-05$ \\
\hline $\mathrm{U}$ & $3.75 \mathrm{E}-04$ & $6.28 \mathrm{E}-04$ & $6.68 \mathrm{E}-04$ & $4.31 \mathrm{E}-05$ \\
\hline V & 8.60E-06 & $1.84 \mathrm{E}-05$ & $2.51 \mathrm{E}-05$ & $1.31 \mathrm{E}-07$ \\
\hline Y & $3.68 \mathrm{E}-06$ & $1.18 \mathrm{E}-05$ & 7.05E-06 & 7.32E-07 \\
\hline $\mathrm{Zn}$ & $9.90 \mathrm{E}-04$ & $1.65 \mathrm{E}-04$ & $1.07 \mathrm{E}-03$ & $1.10 \mathrm{E}-05$ \\
\hline \multirow[t]{2}{*}{$\mathrm{Zr}$} & $5.97 \mathrm{E}-05$ & $1.20 \mathrm{E}-02$ & $3.56 \mathrm{E}-04$ & 8.38E-04 \\
\hline & $\mathrm{g} /$ liter & $\mathrm{g} /$ liter & $\mathrm{g} /$ liter & $\mathrm{g} /$ liter \\
\hline TOC & 0.21 & 0.58 & 0.58 & \\
\hline UDS & 0.246 & 2.5 & 2.5 & \\
\hline Settled Solids & 4.8 & 4.6 & 9.4 & 300 \\
\hline SG & 1.26 & 1.30 & 1.33 & 1.01 \\
\hline \multicolumn{5}{|l|}{ Radionuclides } \\
\hline Ra-226 & $4.25 \mathrm{E}-12$ & $1.37 \mathrm{E}-11$ & $8.14 \mathrm{E}-12$ & $8.45 \mathrm{E}-13$ \\
\hline Ac-227 & $2.00 \mathrm{E}-11$ & $6.44 \mathrm{E}-11$ & $3.83 \mathrm{E}-11$ & $3.98 \mathrm{E}-12$ \\
\hline Th-228 & $1.66 \mathrm{E}-09$ & 5.34E-09 & $3.18 \mathrm{E}-09$ & $3.30 \mathrm{E}-10$ \\
\hline Th-229 & $9.86 \mathrm{E}-14$ & $3.17 \mathrm{E}-13$ & $1.89 \mathrm{E}-13$ & $1.96 \mathrm{E}-14$ \\
\hline Th-230 & $4.27 \mathrm{E}-10$ & $1.37 \mathrm{E}-09$ & $8.17 \mathrm{E}-10$ & $8.48 \mathrm{E}-11$ \\
\hline Th-232 & $3.68 \mathrm{E}-16$ & $1.18 \mathrm{E}-15$ & $7.04 \mathrm{E}-16$ & $7.30 \mathrm{E}-17$ \\
\hline Th-234 & $1.07 \mathrm{E}-08$ & $3.45 \mathrm{E}-08$ & $2.06 \mathrm{E}-08$ & 2.13E-09 \\
\hline $\mathrm{Pa}-231$ & 4.64E-11 & $1.49 \mathrm{E}-10$ & $8.88 \mathrm{E}-11$ & $9.21 \mathrm{E}-12$ \\
\hline $\mathrm{Pa}-233$ & $1.52 \mathrm{E}-06$ & $4.89 \mathrm{E}-06$ & $2.91 \mathrm{E}-06$ & $3.02 \mathrm{E}-07$ \\
\hline U-232 & $1.03 \mathrm{E}-09$ & 3.32E-09 & 1.97E-09 & $2.05 \mathrm{E}-10$ \\
\hline U-233 & $4.15 \mathrm{E}-11$ & $1.33 \mathrm{E}-10$ & $7.94 \mathrm{E}-11$ & $8.25 \mathrm{E}-12$ \\
\hline U-234 & $1.07 \mathrm{E}-06$ & $1.14 \mathrm{E}-06$ & $1.74 \mathrm{E}-06$ & $4.34 \mathrm{E}-08$ \\
\hline U-235 & $3.95 \mathrm{E}-08$ & $3.25 \mathrm{E}-08$ & $6.01 \mathrm{E}-08$ & $1.78 \mathrm{E}-09$ \\
\hline U-236 & $5.84 \mathrm{E}-08$ & 4.73E-08 & $7.81 \mathrm{E}-08$ & $1.82 \mathrm{E}-09$ \\
\hline U-237 & 3.34E-09 & $1.07 \mathrm{E}-08$ & $6.39 \mathrm{E}-09$ & $6.64 \mathrm{E}-10$ \\
\hline U-238 & $2.34 \mathrm{E}-08$ & $4.48 \mathrm{E}-08$ & $4.35 \mathrm{E}-08$ & $3.15 \mathrm{E}-09$ \\
\hline Np-236 & $1.59 \mathrm{E}-12$ & $5.12 \mathrm{E}-12$ & $3.05 \mathrm{E}-12$ & $3.16 \mathrm{E}-13$ \\
\hline Np-237 & $1.22 \mathrm{E}-06$ & $4.76 \mathrm{E}-06$ & $4.59 \mathrm{E}-07$ & $2.03 \mathrm{E}-07$ \\
\hline Np-239 & $1.11 \mathrm{E}-08$ & $3.58 \mathrm{E}-08$ & $2.13 \mathrm{E}-08$ & $2.21 \mathrm{E}-09$ \\
\hline Pu-236 & $1.42 \mathrm{E}-09$ & 4.57E-09 & 2.72E-09 & $2.82 \mathrm{E}-10$ \\
\hline $\mathrm{Pu}-238$ & $5.71 \mathrm{E}-04$ & $6.66 \mathrm{E}-04$ & $3.87 \mathrm{E}-04$ & $8.01 \mathrm{E}-05$ \\
\hline Pu-239 & $8.27 \mathrm{E}-05$ & $8.98 \mathrm{E}-05$ & $4.35 \mathrm{E}-05$ & $4.19 \mathrm{E}-06$ \\
\hline $\mathrm{Pu}-240$ & $5.26 \mathrm{E}-06$ & $1.68 \mathrm{E}-05$ & $1.01 \mathrm{E}-05$ & $9.08 \mathrm{E}-07$ \\
\hline $\mathrm{Pu}-241$ & $1.36 \mathrm{E}-04$ & & $1.33 \mathrm{E}-02$ & \\
\hline
\end{tabular}


Table 20 (continued).

\begin{tabular}{|c|c|c|c|c|}
\hline & WM-180 & WM-188 & WM-189 & WM-187 \\
\hline & $\mathrm{Ci} /$ liter & $\mathrm{Ci} /$ liter & $\mathrm{Ci} /$ liter & $\mathrm{Ci} /$ liter \\
\hline $\mathrm{Pu}-242$ & 4.10E-09 & $1.37 \mathrm{E}-08$ & 7.85E-09 & $1.36 \mathrm{E}-09$ \\
\hline $\mathrm{Pu}-244$ & $3.52 \mathrm{E}-16$ & $1.13 \mathrm{E}-15$ & $6.73 \mathrm{E}-16$ & $6.98 \mathrm{E}-17$ \\
\hline Am-241 & $7.07 \mathrm{E}-05$ & $8.48 \mathrm{E}-05$ & 7.34E-05 & $6.11 \mathrm{E}-06$ \\
\hline Am-242m & 7.89E-09 & $2.54 \mathrm{E}-08$ & $1.51 \mathrm{E}-08$ & $1.57 \mathrm{E}-09$ \\
\hline Am-243 & $1.11 \mathrm{E}-08$ & $3.58 \mathrm{E}-08$ & 2.13E-08 & $2.21 \mathrm{E}-09$ \\
\hline $\mathrm{Cm}-242$ & $6.51 \mathrm{E}-09$ & 2.09E-08 & $2.98 \mathrm{E}-08$ & $1.29 \mathrm{E}-09$ \\
\hline $\mathrm{Cm}-243$ & $1.47 \mathrm{E}-08$ & $4.74 \mathrm{E}-08$ & $2.82 \mathrm{E}-08$ & 2.93E-09 \\
\hline $\mathrm{Cm}-244$ & $9.15 \mathrm{E}-07$ & $2.94 \mathrm{E}-06$ & $1.05 \mathrm{E}-06$ & $1.82 \mathrm{E}-07$ \\
\hline $\mathrm{Cm}-245$ & $1.55 \mathrm{E}-10$ & $4.98 \mathrm{E}-10$ & $2.96 \mathrm{E}-10$ & $3.08 \mathrm{E}-11$ \\
\hline $\mathrm{Cm}-246$ & $1.02 \mathrm{E}-11$ & $3.28 \mathrm{E}-11$ & $1.95 \mathrm{E}-11$ & $2.03 \mathrm{E}-12$ \\
\hline $\mathrm{H}-3$ & $1.82 \mathrm{E}-05$ & $1.96 \mathrm{E}-05$ & $9.66 \mathrm{E}-06$ & $2.87 \mathrm{E}-06$ \\
\hline Be-10 & $1.56 \mathrm{E}-12$ & $5.01 \mathrm{E}-12$ & $2.98 \mathrm{E}-12$ & $3.09 \mathrm{E}-13$ \\
\hline C-14 & $6.23 \mathrm{E}-11$ & $1.71 \mathrm{E}-10$ & $1.19 \mathrm{E}-10$ & $6.62 \mathrm{E}-12$ \\
\hline $\mathrm{Se}-79$ & $2.27 \mathrm{E}-07$ & $7.29 \mathrm{E}-07$ & 4.34E-07 & $4.50 \mathrm{E}-08$ \\
\hline $\mathrm{Rb}-87$ & $1.52 \mathrm{E}-11$ & $4.89 \mathrm{E}-11$ & $2.91 \mathrm{E}-11$ & $3.02 \mathrm{E}-12$ \\
\hline Sr-90 & $2.03 \mathrm{E}-02$ & $6.85 \mathrm{E}-02$ & $3.88 \mathrm{E}-02$ & $4.89 \mathrm{E}-03$ \\
\hline Y-90 & 2.03E-02 & $8.58 \mathrm{E}-02$ & $3.88 \mathrm{E}-02$ & $5.30 \mathrm{E}-03$ \\
\hline Zr-93 & $1.15 \mathrm{E}-06$ & $3.70 \mathrm{E}-06$ & $2.20 \mathrm{E}-06$ & $2.28 \mathrm{E}-07$ \\
\hline Nb-93m & $8.86 \mathrm{E}-07$ & $2.85 \mathrm{E}-06$ & $1.70 \mathrm{E}-06$ & $1.76 \mathrm{E}-07$ \\
\hline $\mathrm{Nb}-94$ & 5.91E-07 & $1.90 \mathrm{E}-06$ & $1.13 \mathrm{E}-06$ & $1.17 \mathrm{E}-07$ \\
\hline Тc-98 & $1.34 \mathrm{E}-12$ & $4.30 \mathrm{E}-12$ & $2.56 \mathrm{E}-12$ & $2.66 \mathrm{E}-13$ \\
\hline Тc-99 & $9.38 \mathrm{E}-06$ & $1.76 \mathrm{E}-05$ & $9.96 \mathrm{E}-06$ & $1.15 \mathrm{E}-06$ \\
\hline Ru-106 & 4.83E-07 & $2.82 \mathrm{E}-06$ & $9.24 \mathrm{E}-07$ & $6.17 \mathrm{E}-07$ \\
\hline Rh-102 & $4.47 \mathrm{E}-10$ & $1.44 \mathrm{E}-09$ & $8.56 \mathrm{E}-10$ & $8.89 \mathrm{E}-11$ \\
\hline Rh-106 & $4.83 \mathrm{E}-07$ & $1.55 \mathrm{E}-06$ & $9.24 \mathrm{E}-07$ & $9.59 \mathrm{E}-08$ \\
\hline Pd-107 & 8.57E-09 & $2.76 \mathrm{E}-08$ & $1.64 \mathrm{E}-08$ & $1.70 \mathrm{E}-09$ \\
\hline Cd-113m & $1.72 \mathrm{E}-06$ & $5.54 \mathrm{E}-06$ & $3.30 \mathrm{E}-06$ & $3.42 \mathrm{E}-07$ \\
\hline In-115 & $5.23 \mathrm{E}-17$ & $1.68 \mathrm{E}-16$ & $1.00 \mathrm{E}-16$ & $1.04 \mathrm{E}-17$ \\
\hline Sn-121m & $3.47 \mathrm{E}-08$ & $1.12 \mathrm{E}-07$ & $6.64 \mathrm{E}-08$ & $6.89 \mathrm{E}-09$ \\
\hline Sn-126 & $2.13 \mathrm{E}-07$ & $6.85 \mathrm{E}-07$ & $4.08 \mathrm{E}-07$ & $4.24 \mathrm{E}-08$ \\
\hline Sb-125 & $6.70 \mathrm{E}-06$ & $2.31 \mathrm{E}-05$ & $1.28 \mathrm{E}-05$ & $3.46 \mathrm{E}-06$ \\
\hline Sb-126 & 2.99E-08 & $9.60 \mathrm{E}-08$ & $5.71 \mathrm{E}-08$ & $5.93 \mathrm{E}-09$ \\
\hline Тe-123 & $1.99 \mathrm{E}-19$ & $6.39 \mathrm{E}-19$ & $3.81 \mathrm{E}-19$ & $3.95 \mathrm{E}-20$ \\
\hline Te-125m & $1.63 \mathrm{E}-06$ & $5.26 \mathrm{E}-06$ & $3.13 \mathrm{E}-06$ & $3.25 \mathrm{E}-07$ \\
\hline I-129 & $2.39 \mathrm{E}-08$ & $8.80 \mathrm{E}-08$ & $5.30 \mathrm{E}-08$ & 2.99E-09 \\
\hline Cs-134 & $5.36 \mathrm{E}-06$ & 8.37E-05 & $4.03 \mathrm{E}-05$ & $6.21 \mathrm{E}-06$ \\
\hline Cs-135 & $4.46 \mathrm{E}-07$ & $1.43 \mathrm{E}-06$ & $8.54 \mathrm{E}-07$ & $8.86 \mathrm{E}-08$ \\
\hline Cs-137 & $2.62 \mathrm{E}-02$ & $8.42 \mathrm{E}-02$ & $5.01 \mathrm{E}-02$ & $5.20 \mathrm{E}-03$ \\
\hline Ba-137m & $2.48 \mathrm{E}-02$ & $7.96 \mathrm{E}-02$ & 4.74E-02 & 4.92E-03 \\
\hline La-138 & $9.91 \mathrm{E}-17$ & $3.19 \mathrm{E}-16$ & $1.90 \mathrm{E}-16$ & $1.97 \mathrm{E}-17$ \\
\hline Ce-142 & $1.55 \mathrm{E}-11$ & 4.99E-11 & $2.97 \mathrm{E}-11$ & $3.08 \mathrm{E}-12$ \\
\hline Ce-144 & $3.25 \mathrm{E}-07$ & $1.74 \mathrm{E}-06$ & $6.23 \mathrm{E}-07$ & $3.42 \mathrm{E}-07$ \\
\hline Pr-144m & $3.90 \mathrm{E}-09$ & $1.25 \mathrm{E}-08$ & 7.47E-09 & $7.75 \mathrm{E}-10$ \\
\hline Pr-144 & $3.25 \mathrm{E}-07$ & $1.05 \mathrm{E}-06$ & $6.23 \mathrm{E}-07$ & $6.46 \mathrm{E}-08$ \\
\hline Nd-144 & $8.34 \mathrm{E}-16$ & $2.68 \mathrm{E}-15$ & $1.60 \mathrm{E}-15$ & $1.66 \mathrm{E}-16$ \\
\hline Pm-146 & 2.64E-08 & $8.49 \mathrm{E}-08$ & $5.05 \mathrm{E}-08$ & $5.25 \mathrm{E}-09$ \\
\hline Pm-147 & $8.84 \mathrm{E}-05$ & $2.84 \mathrm{E}-04$ & $1.69 \mathrm{E}-04$ & $1.76 \mathrm{E}-05$ \\
\hline Sm-146 & $1.43 \mathrm{E}-13$ & $4.60 \mathrm{E}-13$ & $2.74 \mathrm{E}-13$ & $2.84 \mathrm{E}-14$ \\
\hline Sm-147 & $3.82 \mathrm{E}-12$ & $1.23 \mathrm{E}-11$ & 7.32E-12 & $7.60 \mathrm{E}-13$ \\
\hline Sm-148 & $1.96 \mathrm{E}-17$ & $6.32 \mathrm{E}-17$ & $3.76 \mathrm{E}-17$ & $3.90 \mathrm{E}-18$ \\
\hline Sm-149 & $1.74 \mathrm{E}-18$ & & $3.34 \mathrm{E}-18$ & \\
\hline
\end{tabular}


Table 20 (continued).

\begin{tabular}{lllll} 
& WM-180 & WM-188 & WM-189 & WM-187 \\
& Ci/liter & Ci/liter & Ci/liter & Ci/liter \\
Sm-151 & 1.74E-04 & $5.60 \mathrm{E}-04$ & $3.33 \mathrm{E}-04$ & $3.46 \mathrm{E}-05$ \\
Eu-150 & $7.46 \mathrm{E}-12$ & $2.40 \mathrm{E}-11$ & $1.43 \mathrm{E}-11$ & $1.48 \mathrm{E}-12$ \\
Eu-152 & $1.31 \mathrm{E}-06$ & $4.20 \mathrm{E}-06$ & $2.50 \mathrm{E}-06$ & $2.59 \mathrm{E}-07$ \\
Eu-154 & $4.64 \mathrm{E}-05$ & $2.89 \mathrm{E}-04$ & $1.84 \mathrm{E}-04$ & $2.68 \mathrm{E}-05$ \\
Eu-155 & $8.52 \mathrm{E}-05$ & $2.36 \mathrm{E}-04$ & $1.63 \mathrm{E}-04$ & $7.44 \mathrm{E}-06$ \\
Gd-152 & $7.38 \mathrm{E}-19$ & $2.37 \mathrm{E}-18$ & $1.41 \mathrm{E}-18$ & $1.47 \mathrm{E}-19$ \\
Ho-166m & $2.39 \mathrm{E}-11$ & $7.68 \mathrm{E}-11$ & $4.57 \mathrm{E}-11$ & $4.75 \mathrm{E}-12$ \\
Co-60 & 4.14E-06 & $6.16 \mathrm{E}-05$ & $3.62 \mathrm{E}-05$ & $7.00 \mathrm{E}-06$ \\
Ni-63 & $2.46 \mathrm{E}-05$ & $5.26 \mathrm{E}-05$ & $3.14 \mathrm{E}-05$ & $6.94 \mathrm{E}-06$ \\
\hline
\end{tabular}

Table 21 presents suggested compositions for generated waste, that is, NGLW generated 2006 through 2011 combined with the excess SBW generated from 2003-2005 (beyond what can be sent to Tank WM-188). The composition is expanded from Tables 16-18 assuming concentrations of other species are equivalent to the average for Tanks WM-180, WM-188 and WM-189. For steam reforming, either the Calcine/MACT composition could be used, if significant volumes of nitric acid are expected to be used during operation, or the CsIX alternative, if little or no nitric acid is expected to be used in decontamination and turnaround activities.

Table 21. Estimated Generated Waste Composition.

\begin{tabular}{|c|c|c|c|c|c|}
\hline & Calcination & CsIX & Dir Evap & & All alternatives \\
\hline \multirow[t]{2}{*}{ Gallons } & \multirow{2}{*}{$\begin{array}{l}82,800 \\
\text { mol/liter }\end{array}$} & \multirow{2}{*}{$\begin{array}{l}87,400 \\
\text { mol/liter }\end{array}$} & \multirow{2}{*}{$\begin{array}{l}53,000 \\
\mathrm{~mol} / \text { liter }\end{array}$} & \multicolumn{2}{|r|}{ Ci/liter } \\
\hline & & & & Ra-226 & $8.7 \mathrm{E}-12$ \\
\hline $\mathrm{H}+$ & $2.7 \mathrm{E}+00$ & $4.1 \mathrm{E}+00$ & $1.2 \mathrm{E}+00$ & Ac-227 & $4.1 \mathrm{E}-11$ \\
\hline $\mathrm{Al}$ & $2.3 \mathrm{E}-01$ & $1.4 \mathrm{E}-01$ & $2.4 \mathrm{E}-01$ & Th-228 & $3.4 \mathrm{E}-09$ \\
\hline $\mathrm{Am}$ & $9.3 \mathrm{E}-08$ & $9.3 \mathrm{E}-08$ & 9.3E-08 & Th-229 & $2.0 \mathrm{E}-13$ \\
\hline $\mathrm{Sb}$ & $2.0 \mathrm{E}-05$ & $1.2 \mathrm{E}-05$ & $2.0 \mathrm{E}-05$ & Th-230 & $8.8 \mathrm{E}-10$ \\
\hline As & $6.0 \mathrm{E}-05$ & $3.6 \mathrm{E}-05$ & $6.8 \mathrm{E}-05$ & Th-232 & $7.6 \mathrm{E}-16$ \\
\hline $\mathrm{Ba}$ & 4.1E-05 & $2.5 \mathrm{E}-05$ & 4.3E-05 & Th-234 & 2.2E-08 \\
\hline $\mathrm{Be}$ & $3.7 \mathrm{E}-06$ & $2.7 \mathrm{E}-06$ & 4.3E-06 & Pa-231 & $9.5 \mathrm{E}-11$ \\
\hline B & $6.6 \mathrm{E}-03$ & 4.0E-03 & 7.4E-03 & $\mathrm{Pa}-233$ & $3.1 \mathrm{E}-06$ \\
\hline $\mathrm{Br}$ & $3.4 \mathrm{E}-07$ & $3.4 \mathrm{E}-07$ & $3.4 \mathrm{E}-07$ & U-232 & 2.1E-09 \\
\hline $\mathrm{Cd}$ & $9.4 \mathrm{E}-04$ & $6.7 \mathrm{E}-04$ & $1.3 \mathrm{E}-03$ & U-233 & $8.5 \mathrm{E}-11$ \\
\hline $\mathrm{Ca}$ & $2.2 \mathrm{E}-02$ & $1.4 \mathrm{E}-02$ & $2.3 \mathrm{E}-02$ & U-234 & $1.3 \mathrm{E}-06$ \\
\hline $\mathrm{C}$ & $3.9 \mathrm{E}-06$ & $3.9 \mathrm{E}-06$ & $3.9 \mathrm{E}-06$ & U-235 & 4.4E-08 \\
\hline $\mathrm{Ce}$ & $3.6 \mathrm{E}-05$ & $3.6 \mathrm{E}-05$ & $3.6 \mathrm{E}-05$ & U-236 & $6.1 \mathrm{E}-08$ \\
\hline $\mathrm{Cs}$ & $2.3 \mathrm{E}-05$ & $2.3 \mathrm{E}-05$ & 2.3E-05 & U-237 & 6.9E-09 \\
\hline $\mathrm{Cl}$ & $1.3 \mathrm{E}-02$ & $1.1 \mathrm{E}-02$ & $1.5 \mathrm{E}-02$ & U-238 & $3.3 \mathrm{E}-08$ \\
\hline $\mathrm{Cr}$ & 4.4E-03 & $4.2 \mathrm{E}-03$ & $6.2 \mathrm{E}-03$ & $\mathrm{~Np}-236$ & $3.3 \mathrm{E}-12$ \\
\hline $\mathrm{Co}$ & $2.2 \mathrm{E}-05$ & $1.0 \mathrm{E}-04$ & $2.8 \mathrm{E}-05$ & $\mathrm{~Np}-237$ & $2.2 \mathrm{E}-06$ \\
\hline $\mathrm{Cu}$ & $2.6 \mathrm{E}-04$ & $1.9 \mathrm{E}-04$ & $3.3 \mathrm{E}-04$ & $\mathrm{~Np}-239$ & $2.3 \mathrm{E}-08$ \\
\hline $\mathrm{Cm}$ & $1.1 \mathrm{E}-10$ & $1.1 \mathrm{E}-10$ & $1.1 \mathrm{E}-10$ & $\mathrm{Pu}-236$ & 2.9E-09 \\
\hline Dy & $6.9 \mathrm{E}-10$ & $6.9 \mathrm{E}-10$ & $6.9 \mathrm{E}-10$ & $\mathrm{Pu}-238$ & $5.4 \mathrm{E}-04$ \\
\hline $\mathrm{Eu}$ & $5.6 \mathrm{E}-07$ & $5.6 \mathrm{E}-07$ & $5.6 \mathrm{E}-07$ & $\mathrm{Pu}-239$ & 7.2E-05 \\
\hline $\mathrm{F}$ & $3.7 \mathrm{E}-02$ & $3.5 \mathrm{E}-02$ & 4.7E-02 & $\mathrm{Pu}-240$ & $1.1 \mathrm{E}-05$ \\
\hline Gd & $1.2 \mathrm{E}-04$ & $1.2 \mathrm{E}-04$ & $1.2 \mathrm{E}-04$ & $\mathrm{Pu}-241$ & 4.6E-03 \\
\hline $\mathrm{Ge}$ & 9.7E-09 & 9.7E-09 & 9.7E-09 & $\mathrm{Pu}-242$ & 8.6E-09 \\
\hline In & $1.5 \mathrm{E}-07$ & $1.5 \mathrm{E}-07$ & $1.5 \mathrm{E}-07$ & $\mathrm{Pu}-244$ & $7.2 \mathrm{E}-16$ \\
\hline I & $2.8 \mathrm{E}-06$ & $2.8 \mathrm{E}-06$ & $2.8 \mathrm{E}-06$ & Am-241 & 7.6E-05 \\
\hline
\end{tabular}


Table 21. (Continued).

\begin{tabular}{|c|c|c|c|c|c|}
\hline & Calcination & CsIX & Dir Evap & & All alternatives \\
\hline & $\mathrm{mol} /$ liter & $\mathrm{mol} / \mathrm{liter}$ & $\mathrm{mol} /$ liter & & $\mathrm{Ci} /$ liter \\
\hline $\mathrm{Fe}$ & $8.6 \mathrm{E}-03$ & $6.2 \mathrm{E}-03$ & $9.4 \mathrm{E}-03$ & Am-242m & $1.6 \mathrm{E}-08$ \\
\hline $\mathrm{La}$ & $1.0 \mathrm{E}-05$ & $1.0 \mathrm{E}-05$ & $1.0 \mathrm{E}-05$ & Am-243 & $2.3 \mathrm{E}-08$ \\
\hline $\mathrm{Pb}$ & 4.7E-04 & $6.6 \mathrm{E}-04$ & $6.4 \mathrm{E}-04$ & $\mathrm{Cm}-242$ & $1.9 \mathrm{E}-08$ \\
\hline $\mathrm{Li}$ & $2.5 \mathrm{E}-04$ & $2.5 \mathrm{E}-04$ & $2.5 \mathrm{E}-04$ & $\mathrm{Cm}-243$ & $3.0 \mathrm{E}-08$ \\
\hline $\mathrm{Mg}$ & $1.4 \mathrm{E}-02$ & $1.4 \mathrm{E}-02$ & $1.4 \mathrm{E}-02$ & $\mathrm{Cm}-244$ & $1.6 \mathrm{E}-06$ \\
\hline $\mathrm{Mn}$ & $2.5 \mathrm{E}-02$ & $2.2 \mathrm{E}-02$ & $3.6 \mathrm{E}-02$ & $\mathrm{Cm}-245$ & $3.2 \mathrm{E}-10$ \\
\hline $\mathrm{Hg}$ & $5.3 \mathrm{E}-03$ & $2.1 \mathrm{E}-03$ & $3.0 \mathrm{E}-03$ & $\mathrm{Cm}-246$ & $2.1 \mathrm{E}-11$ \\
\hline Mo & $1.8 \mathrm{E}-04$ & $1.8 \mathrm{E}-04$ & $1.8 \mathrm{E}-04$ & $\mathrm{H}-3$ & $1.6 \mathrm{E}-05$ \\
\hline $\mathrm{Nd}$ & $3.3 \mathrm{E}-05$ & $3.3 \mathrm{E}-05$ & $3.3 \mathrm{E}-05$ & $\mathrm{Be}-10$ & $3.2 \mathrm{E}-12$ \\
\hline $\mathrm{Np}$ & $1.9 \mathrm{E}-05$ & $1.9 \mathrm{E}-05$ & $1.9 \mathrm{E}-05$ & C-14 & $1.2 \mathrm{E}-10$ \\
\hline $\mathrm{Ni}$ & $8.1 \mathrm{E}-04$ & 8.3E-04 & $1.0 \mathrm{E}-03$ & Se-79 & 4.7E-07 \\
\hline $\mathrm{Nb}$ & $1.2 \mathrm{E}-06$ & $1.2 \mathrm{E}-06$ & $1.2 \mathrm{E}-06$ & $\mathrm{Rb}-87$ & $3.1 \mathrm{E}-11$ \\
\hline NO3 & $6.7 \mathrm{E}+00$ & $7.6 \mathrm{E}+00$ & $6.2 \mathrm{E}+00$ & Sr-90 & 4.3E-02 \\
\hline $\mathrm{Pd}$ & $3.9 \mathrm{E}-06$ & $3.9 \mathrm{E}-06$ & $3.9 \mathrm{E}-06$ & $Y-90$ & 4.3E-02 \\
\hline PO4 & $2.8 \mathrm{E}-03$ & $1.6 \mathrm{E}-03$ & 2.9E-03 & Zr-93 & $2.4 \mathrm{E}-06$ \\
\hline $\mathrm{Pu}$ & $5.4 \mathrm{E}-06$ & $5.4 \mathrm{E}-06$ & $5.4 \mathrm{E}-06$ & $\mathrm{Nb}-93 \mathrm{~m}$ & $1.8 \mathrm{E}-06$ \\
\hline K & $4.8 \mathrm{E}-01$ & 7.6E-01 & $6.6 \mathrm{E}-01$ & $\mathrm{Nb}-94$ & $1.2 \mathrm{E}-06$ \\
\hline $\operatorname{Pr}$ & $9.2 \mathrm{E}-06$ & $9.2 \mathrm{E}-06$ & $9.2 \mathrm{E}-06$ & Tc-98 & $2.8 \mathrm{E}-12$ \\
\hline $\mathrm{Pm}$ & $1.4 \mathrm{E}-09$ & $1.4 \mathrm{E}-09$ & $1.4 \mathrm{E}-09$ & Tc-99 & $1.2 \mathrm{E}-05$ \\
\hline $\mathrm{Rh}$ & $4.0 \mathrm{E}-06$ & $4.0 \mathrm{E}-06$ & $4.0 \mathrm{E}-06$ & Ru-106 & $1.4 \mathrm{E}-06$ \\
\hline $\mathrm{Rb}$ & $6.1 \mathrm{E}-06$ & $6.1 \mathrm{E}-06$ & $6.1 \mathrm{E}-06$ & Rh-102 & $9.2 \mathrm{E}-10$ \\
\hline $\mathrm{Ru}$ & $1.1 \mathrm{E}-04$ & $1.1 \mathrm{E}-04$ & $1.1 \mathrm{E}-04$ & Rh-106 & $1.4 \mathrm{E}-06$ \\
\hline $\mathrm{Sm}$ & $6.1 \mathrm{E}-06$ & $6.1 \mathrm{E}-06$ & $6.1 \mathrm{E}-06$ & Pd-107 & $1.8 \mathrm{E}-08$ \\
\hline $\mathrm{Se}$ & 2.3E-05 & $1.1 \mathrm{E}-05$ & $1.8 \mathrm{E}-05$ & Cd-113m & $3.5 \mathrm{E}-06$ \\
\hline $\mathrm{Si}$ & 7.9E-04 & 7.9E-04 & 7.9E-04 & In-115 & $1.1 \mathrm{E}-16$ \\
\hline $\mathrm{Ag}$ & $6.7 \mathrm{E}-06$ & $3.6 \mathrm{E}-06$ & $6.5 \mathrm{E}-06$ & Sn-121m & $7.1 \mathrm{E}-08$ \\
\hline $\mathrm{Na}$ & $2.4 \mathrm{E}+00$ & $2.0 \mathrm{E}+00$ & $3.3 \mathrm{E}+00$ & Sn-126 & $4.4 \mathrm{E}-07$ \\
\hline $\mathrm{Sr}$ & $9.1 \mathrm{E}-05$ & $9.1 \mathrm{E}-05$ & $9.1 \mathrm{E}-05$ & Sb-125 & $1.4 \mathrm{E}-05$ \\
\hline SO4 & $2.5 \mathrm{E}-02$ & $1.5 \mathrm{E}-02$ & $2.6 \mathrm{E}-02$ & Sb-126 & $6.1 \mathrm{E}-08$ \\
\hline Tc & $7.4 \mathrm{E}-06$ & $7.4 \mathrm{E}-06$ & $7.4 \mathrm{E}-06$ & Te-123 & $4.1 \mathrm{E}-19$ \\
\hline $\mathrm{Te}$ & 4.6E-06 & 4.6E-06 & 4.6E-06 & Te-125m & $3.4 \mathrm{E}-06$ \\
\hline $\mathrm{Tb}$ & 2.3E-09 & 2.3E-09 & 2.3E-09 & I-129 & $5.5 \mathrm{E}-08$ \\
\hline $\mathrm{Tl}$ & $9.7 \mathrm{E}-06$ & $4.0 \mathrm{E}-06$ & 7.2E-06 & Cs-134 & $4.4 \mathrm{E}-05$ \\
\hline Th & $1.2 \mathrm{E}-05$ & $1.2 \mathrm{E}-05$ & $1.2 \mathrm{E}-05$ & Cs-135 & $9.2 \mathrm{E}-07$ \\
\hline $\mathrm{Tm}$ & $5.4 \mathrm{E}-15$ & $5.4 \mathrm{E}-15$ & $5.4 \mathrm{E}-15$ & Cs-137 & $5.4 \mathrm{E}-02$ \\
\hline $\mathrm{Sn}$ & $1.4 \mathrm{E}-05$ & $1.4 \mathrm{E}-05$ & $1.4 \mathrm{E}-05$ & $\mathrm{Ba}-137 \mathrm{~m}$ & $5.1 \mathrm{E}-02$ \\
\hline $\mathrm{Ti}$ & $6.2 \mathrm{E}-05$ & $6.2 \mathrm{E}-05$ & $6.2 \mathrm{E}-05$ & La-138 & $2.0 \mathrm{E}-16$ \\
\hline $\mathrm{U}$ & $9.7 \mathrm{E}-05$ & $1.2 \mathrm{E}-02$ & $1.3 \mathrm{E}-04$ & $\mathrm{Ce}-142$ & $3.2 \mathrm{E}-11$ \\
\hline V & $8.5 \mathrm{E}-05$ & 5.9E-05 & $1.1 \mathrm{E}-04$ & $\mathrm{Ce}-144$ & $9.0 \mathrm{E}-07$ \\
\hline $\mathrm{Y}$ & $7.6 \mathrm{E}-06$ & 7.6E-06 & $7.6 \mathrm{E}-06$ & $\operatorname{Pr}-144 \mathrm{~m}$ & 8.0E-09 \\
\hline $\mathrm{Zn}$ & $7.1 \mathrm{E}-04$ & $4.4 \mathrm{E}-04$ & 7.7E-04 & Pr-144 & $6.7 \mathrm{E}-07$ \\
\hline \multirow[t]{2}{*}{$\mathrm{Zr}$} & $2.1 \mathrm{E}-03$ & $1.3 \mathrm{E}-03$ & $2.7 \mathrm{E}-03$ & Nd-144 & $1.7 \mathrm{E}-15$ \\
\hline & $\mathrm{g} /$ liter & $\mathrm{g} /$ liter & $\mathrm{g} /$ liter & Pm-146 & $5.4 \mathrm{E}-08$ \\
\hline UDS & $4.6 \mathrm{E}+00$ & $3.3 \mathrm{E}+00$ & $5.3 \mathrm{E}+00$ & Pm-147 & $1.8 \mathrm{E}-04$ \\
\hline \multirow[t]{2}{*}{ TOC } & $4.6 \mathrm{E}+00$ & $4.6 \mathrm{E}+00$ & $6.2 \mathrm{E}+00$ & Sm-146 & $2.9 \mathrm{E}-13$ \\
\hline & & & & Sm-147 & $7.9 \mathrm{E}-12$ \\
\hline \multirow{5}{*}{$\begin{array}{l}\text { LET\&D Bottoms, } \\
\text { gallons }\end{array}$} & & & & Sm-148 & $4.0 \mathrm{E}-17$ \\
\hline & reused & 0 & 31,000 & Sm-149 & $3.6 \mathrm{E}-18$ \\
\hline & & & & Sm-151 & $3.6 \mathrm{E}-04$ \\
\hline & & & & Eu-150 & $1.5 \mathrm{E}-11$ \\
\hline & & & & Eu-152 & $2.7 \mathrm{E}-06$ \\
\hline
\end{tabular}


Table 21. (Continued).

\begin{tabular}{lll}
\hline & & $\underline{\text { Ci/liter }}$ \\
\hline & Eu-154 & $1.7 \mathrm{E}-04$ \\
Composition for calcination and direct evaporation & Eu-155 & $1.6 \mathrm{E}-04$ \\
assume 4:1 water dilution during evaporation & Gd-152 & $1.5 \mathrm{E}-18$ \\
& Ho-166m & $4.9 \mathrm{E}-11$ \\
Composition for CsIX alternative includes all & Co-60 & $3.4 \mathrm{E}-05$ \\
LET\&D bottoms & Ni-63 & $3.6 \mathrm{E}-05$ \\
\hline
\end{tabular}

\subsubsection{Liquid Composition for Solids Coprocessing Feeds}

For treatment alternatives that co-process tank solids with SBW liquid, one method of preparing the mixed solids/liquid feed is to transfer a portion of the solids collected in Tank WM-187 to tanks of SBW liquid ${ }^{16}$. Several scenarios for accomplishing this have been suggested (see Reference 16) and evaluated based on criteria of:

- Obtaining as similar a concentration of solids as possible in the different tanks

- $\quad$ Minimizing the number of tank transfers

- $\quad$ Keeping the solids concentration in transfers below the level at which solids would settle in transfer piping

- $\quad$ Keeping one tank available for receiving dilute wastes from tank closure activities and SBW treatment processes

- $\quad$ Avoiding transfers to WM-180.

The recommended scenario ${ }^{16}$ involves transferring liquid waste from Tanks WM-188 and WM-189 into WM-187, and then transferring mixed WM-187 solids/liquid waste back to WM-188 and WM-189. Based on tank volumes determined in this report, the recommended scenario is shown in Table 22. Except for Tank WM-189, transfers between tanks assume 3\% dilution from steam jets and transfers to treatment assume 5\% dilution. An existing air-lift is assumed to be used to transfer waste from WM-189 to the 30,000 gal level, and steams jets to lower levels. Liquid compositions for this scenario are given in Table 23. As additional sampling and analyses are performed on tank wastes, additional tank mixing scenarios should be evaluated.

Table 22. Tank mixing scenario.

\begin{tabular}{llllllll}
\hline & $\begin{array}{l}\text { Initial volume } \\
\text { gallons }\end{array}$ & $\begin{array}{l}\text { Fill WM- } \\
187\end{array}$ & $\begin{array}{l}\text { Transfer } \\
\text { solids from } \\
\text { WM-187 }\end{array}$ & $\begin{array}{l}\text { add NGLW to } \\
\text { WM-187 }\end{array}$ & $\begin{array}{l}\text { Volume } \\
\text { transferred to } \\
\text { treatment }\end{array}$ & $\begin{array}{l}\text { Rounded, } \\
\text { gallons }\end{array}$ & $\begin{array}{l}\text { ave solids, } \\
\text { g/liter }\end{array}$ \\
& 276,000 & & & & 289,800 & 290,000 & 5 \\
WM-180 & 285,000 & $-98,000$ & 98,000 & & 299,250 & 299,000 & 36 \\
WM-188 & 280,100 & $-93,100$ & 98,000 & & 286,500 & 286,500 & 39 \\
WM-189 & 82,800 & & & $-82,800$ & & & \\
$\begin{array}{l}\text { Gen'd waste } \\
\text { Subtotal }\end{array}$ & 923,900 & & & & 875,550 & 875,500 & \\
WM-187 & 88,000 & 194,040 & $-190,290$ & 85,280 & 185,880 & 186,000 & 53 \\
Total & $1,011,900$ & & & & $1,061,430$ & $1,061,500$ & \\
\hline
\end{tabular}


Table 23. Coprocessing Feeds (Calcination with MACT Upgrade Alternative).

\begin{tabular}{|c|c|c|c|c|}
\hline & WM-180 & WM-187 & WM-188 & WM-189 \\
\hline \multirow[t]{2}{*}{ Gallons } & 290,000 & 186,000 & 299,000 & 286,500 \\
\hline & Mol/liter & Mol/liter & Mol/liter & Mol/liter \\
\hline $\mathrm{H}+$ & $1.07 \mathrm{E}+00$ & $2.25 \mathrm{E}+00$ & $2.55 \mathrm{E}+00$ & $2.58 \mathrm{E}+00$ \\
\hline $\mathrm{Al}$ & $5.76 \mathrm{E}-01$ & $3.43 \mathrm{E}-01$ & $5.92 \mathrm{E}-01$ & $6.27 \mathrm{E}-01$ \\
\hline Am & $8.16 \mathrm{E}-08$ & $7.47 \mathrm{E}-08$ & 8.61E-08 & 8.07E-08 \\
\hline $\mathrm{Sb}$ & $3.42 \mathrm{E}-08$ & $1.07 \mathrm{E}-05$ & $2.49 \mathrm{E}-06$ & $6.01 \mathrm{E}-06$ \\
\hline As & 4.49E-04 & $2.90 \mathrm{E}-05$ & $8.36 \mathrm{E}-06$ & $1.65 \mathrm{E}-06$ \\
\hline $\mathrm{Ba}$ & $4.92 \mathrm{E}-05$ & $3.31 \mathrm{E}-05$ & $2.91 \mathrm{E}-05$ & 4.68E-05 \\
\hline $\mathrm{Be}$ & $6.97 \mathrm{E}-06$ & $5.17 \mathrm{E}-06$ & $3.02 \mathrm{E}-06$ & $1.55 \mathrm{E}-05$ \\
\hline B & $1.02 \mathrm{E}-02$ & $1.08 \mathrm{E}-02$ & $1.99 \mathrm{E}-02$ & $1.91 \mathrm{E}-02$ \\
\hline $\mathrm{Br}$ & $1.56 \mathrm{E}-07$ & $2.96 \mathrm{E}-07$ & 4.24E-07 & $3.03 \mathrm{E}-07$ \\
\hline $\mathrm{Cd}$ & $7.12 \mathrm{E}-04$ & $2.03 \mathrm{E}-03$ & 4.27E-03 & $3.63 \mathrm{E}-03$ \\
\hline $\mathrm{Ca}$ & $3.67 \mathrm{E}-02$ & $3.62 \mathrm{E}-02$ & $6.70 \mathrm{E}-02$ & $6.55 \mathrm{E}-02$ \\
\hline $\mathrm{C}$ & $1.81 \mathrm{E}-06$ & $3.43 \mathrm{E}-06$ & 4.91E-06 & $3.52 \mathrm{E}-06$ \\
\hline $\mathrm{Ce}$ & $4.25 \mathrm{E}-05$ & $2.73 \mathrm{E}-05$ & $2.58 \mathrm{E}-05$ & $3.04 \mathrm{E}-05$ \\
\hline Cs & $9.49 \mathrm{E}-06$ & $2.03 \mathrm{E}-05$ & $2.64 \mathrm{E}-05$ & $2.43 \mathrm{E}-05$ \\
\hline $\mathrm{Cl}$ & $2.86 \mathrm{E}-02$ & $1.41 \mathrm{E}-02$ & $2.36 \mathrm{E}-02$ & $1.92 \mathrm{E}-02$ \\
\hline $\mathrm{Cr}$ & $3.32 \mathrm{E}-03$ & 4.03E-03 & $5.23 \mathrm{E}-03$ & $5.06 \mathrm{E}-03$ \\
\hline $\mathrm{Co}$ & $1.73 \mathrm{E}-05$ & $1.89 \mathrm{E}-05$ & $1.13 \mathrm{E}-05$ & $3.64 \mathrm{E}-05$ \\
\hline $\mathrm{Cu}$ & $6.26 \mathrm{E}-04$ & $2.93 \mathrm{E}-04$ & $1.79 \mathrm{E}-04$ & $7.40 \mathrm{E}-04$ \\
\hline $\mathrm{Cm}$ & $4.86 \mathrm{E}-11$ & $9.24 \mathrm{E}-11$ & $1.32 \mathrm{E}-10$ & $9.46 \mathrm{E}-11$ \\
\hline Dy & $3.21 \mathrm{E}-10$ & $6.10 \mathrm{E}-10$ & $8.73 \mathrm{E}-10$ & $6.25 \mathrm{E}-10$ \\
\hline $\mathrm{Eu}$ & $2.59 \mathrm{E}-07$ & 4.92E-07 & $7.03 \mathrm{E}-07$ & $5.03 \mathrm{E}-07$ \\
\hline $\mathrm{F}$ & $4.04 \mathrm{E}-02$ & 4.09E-02 & 8.97E-02 & $2.53 \mathrm{E}-02$ \\
\hline $\mathrm{Gd}$ & $1.59 \mathrm{E}-04$ & 8.29E-05 & $5.03 \mathrm{E}-05$ & $1.09 \mathrm{E}-04$ \\
\hline $\mathrm{Ge}$ & $4.50 \mathrm{E}-09$ & $8.55 \mathrm{E}-09$ & $1.22 \mathrm{E}-08$ & 8.75E-09 \\
\hline In & $6.98 \mathrm{E}-08$ & $1.33 \mathrm{E}-07$ & $1.90 \mathrm{E}-07$ & $1.36 \mathrm{E}-07$ \\
\hline I & $1.30 \mathrm{E}-06$ & $2.46 \mathrm{E}-06$ & $3.52 \mathrm{E}-06$ & $2.52 \mathrm{E}-06$ \\
\hline $\mathrm{Fe}$ & $1.78 \mathrm{E}-02$ & $1.33 \mathrm{E}-02$ & $2.38 \mathrm{E}-02$ & $2.39 \mathrm{E}-02$ \\
\hline $\mathrm{La}$ & $4.70 \mathrm{E}-06$ & 8.93E-06 & $1.28 \mathrm{E}-05$ & $9.14 \mathrm{E}-06$ \\
\hline $\mathrm{Pb}$ & $1.26 \mathrm{E}-03$ & $6.00 \mathrm{E}-04$ & $9.21 \mathrm{E}-04$ & $1.02 \mathrm{E}-03$ \\
\hline $\mathrm{Li}$ & $3.50 \mathrm{E}-04$ & 1.79E-04 & $5.31 \mathrm{E}-05$ & $2.94 \mathrm{E}-04$ \\
\hline $\mathrm{Mg}$ & $1.08 \mathrm{E}-02$ & $1.11 \mathrm{E}-02$ & 8.09E-03 & $1.78 \mathrm{E}-02$ \\
\hline $\mathrm{Mn}$ & $1.27 \mathrm{E}-02$ & $1.54 \mathrm{E}-02$ & $6.02 \mathrm{E}-03$ & $1.56 \mathrm{E}-02$ \\
\hline $\mathrm{Hg}$ & $1.28 \mathrm{E}-03$ & 4.39E-03 & 4.77E-03 & $5.59 \mathrm{E}-03$ \\
\hline Mo & $1.73 \mathrm{E}-04$ & $1.40 \mathrm{E}-04$ & $8.76 \mathrm{E}-05$ & $2.23 \mathrm{E}-04$ \\
\hline $\mathrm{Nd}$ & $1.52 \mathrm{E}-05$ & $2.88 \mathrm{E}-05$ & $4.12 \mathrm{E}-05$ & $2.95 \mathrm{E}-05$ \\
\hline $\mathrm{Np}$ & $8.66 \mathrm{E}-06$ & $1.65 \mathrm{E}-05$ & $2.35 \mathrm{E}-05$ & $1.68 \mathrm{E}-05$ \\
\hline $\mathrm{Ni}$ & $1.37 \mathrm{E}-03$ & $1.31 \mathrm{E}-03$ & $2.60 \mathrm{E}-03$ & $2.15 \mathrm{E}-03$ \\
\hline $\mathrm{Nb}$ & $3.24 \mathrm{E}-08$ & $1.17 \mathrm{E}-06$ & $2.51 \mathrm{E}-06$ & 4.84E-07 \\
\hline NO3 & $4.92 \mathrm{E}+00$ & $5.50 \mathrm{E}+00$ & $6.17 \mathrm{E}+00$ & $6.59 \mathrm{E}+00$ \\
\hline $\mathrm{Pd}$ & $1.80 \mathrm{E}-06$ & $3.41 \mathrm{E}-06$ & $4.88 \mathrm{E}-06$ & $3.49 \mathrm{E}-06$ \\
\hline PO4 & $2.74 \mathrm{E}-03$ & $3.12 \mathrm{E}-03$ & $6.79 \mathrm{E}-03$ & $2.62 \mathrm{E}-03$ \\
\hline $\mathrm{Pu}$ & $5.53 \mathrm{E}-06$ & 4.18E-06 & $5.25 \mathrm{E}-06$ & $3.65 \mathrm{E}-06$ \\
\hline $\mathrm{K}$ & $1.75 \mathrm{E}-01$ & $2.92 \mathrm{E}-01$ & $2.01 \mathrm{E}-01$ & $2.01 \mathrm{E}-01$ \\
\hline $\operatorname{Pr}$ & $4.28 \mathrm{E}-06$ & $8.12 \mathrm{E}-06$ & $1.16 \mathrm{E}-05$ & 8.31E-06 \\
\hline $\mathrm{Pm}$ & $6.26 \mathrm{E}-10$ & 1.19E-09 & $1.70 \mathrm{E}-09$ & $1.22 \mathrm{E}-09$ \\
\hline $\mathrm{Rh}$ & $1.84 \mathrm{E}-06$ & $3.50 \mathrm{E}-06$ & $5.01 \mathrm{E}-06$ & $3.59 \mathrm{E}-06$ \\
\hline $\mathrm{Rb}$ & $2.84 \mathrm{E}-06$ & & & \\
\hline
\end{tabular}


Table 23. (Continued.)

\begin{tabular}{|c|c|c|c|c|}
\hline & $\begin{array}{l}\text { WM-180 } \\
\text { Mol/liter }\end{array}$ & $\begin{array}{l}\text { WM-187 } \\
\text { Mol/liter }\end{array}$ & $\begin{array}{l}\text { WM-188 } \\
\text { Mol/liter }\end{array}$ & $\begin{array}{l}\text { WM-189 } \\
\text { Mol/liter }\end{array}$ \\
\hline $\mathrm{Ru}$ & $1.12 \mathrm{E}-04$ & $8.17 \mathrm{E}-05$ & $4.26 \mathrm{E}-05$ & $1.35 \mathrm{E}-04$ \\
\hline $\mathrm{Sm}$ & $2.81 \mathrm{E}-06$ & $5.34 \mathrm{E}-06$ & 7.64E-06 & $5.47 \mathrm{E}-06$ \\
\hline $\mathrm{Se}$ & $9.88 \mathrm{E}-06$ & $1.14 \mathrm{E}-05$ & $3.38 \mathrm{E}-06$ & $1.26 \mathrm{E}-06$ \\
\hline $\mathrm{Si}$ & $2.66 \mathrm{E}-04$ & $9.78 \mathrm{E}-04$ & $1.51 \mathrm{E}-03$ & $6.21 \mathrm{E}-04$ \\
\hline $\mathrm{Ag}$ & $4.22 \mathrm{E}-06$ & $4.68 \mathrm{E}-06$ & 4.77E-06 & $1.18 \mathrm{E}-06$ \\
\hline $\mathrm{Na}$ & $1.88 \mathrm{E}+00$ & $1.73 \mathrm{E}+00$ & $1.51 \mathrm{E}+00$ & $1.77 \mathrm{E}+00$ \\
\hline $\mathrm{Sr}$ & $1.07 \mathrm{E}-04$ & $6.71 \mathrm{E}-05$ & $2.97 \mathrm{E}-05$ & $1.10 \mathrm{E}-04$ \\
\hline $\mathrm{SO} 4$ & 4.92E-02 & $3.76 \mathrm{E}-02$ & $4.66 \mathrm{E}-02$ & 8.77E-02 \\
\hline $\mathrm{Tc}$ & $5.32 \mathrm{E}-06$ & $6.14 \mathrm{E}-06$ & $8.40 \mathrm{E}-06$ & $5.80 \mathrm{E}-06$ \\
\hline $\mathrm{Te}$ & $1.48 \mathrm{E}-06$ & 4.14E-06 & $4.46 \mathrm{E}-06$ & $6.14 \mathrm{E}-06$ \\
\hline $\mathrm{Tb}$ & $1.08 \mathrm{E}-09$ & $2.06 \mathrm{E}-09$ & 2.94E-09 & $2.10 \mathrm{E}-09$ \\
\hline $\mathrm{Tl}$ & $9.96 \mathrm{E}-21$ & $4.50 \mathrm{E}-06$ & $8.02 \mathrm{E}-07$ & $1.29 \mathrm{E}-07$ \\
\hline $\mathrm{Th}$ & $1.00 \mathrm{E}-10$ & $1.09 \mathrm{E}-05$ & $3.67 \mathrm{E}-06$ & $2.66 \mathrm{E}-05$ \\
\hline $\mathrm{Tm}$ & $2.51 \mathrm{E}-15$ & 4.77E-15 & $6.83 \mathrm{E}-15$ & $4.89 \mathrm{E}-15$ \\
\hline $\mathrm{Sn}$ & $6.02 \mathrm{E}-08$ & $1.32 \mathrm{E}-05$ & $5.03 \mathrm{E}-06$ & $3.16 \mathrm{E}-05$ \\
\hline $\mathrm{Ti}$ & $5.19 \mathrm{E}-05$ & $5.85 \mathrm{E}-05$ & $5.65 \mathrm{E}-05$ & $6.84 \mathrm{E}-05$ \\
\hline $\mathrm{U}$ & $3.57 \mathrm{E}-04$ & $2.66 \mathrm{E}-04$ & $5.37 \mathrm{E}-04$ & $5.86 \mathrm{E}-04$ \\
\hline V & $8.18 \mathrm{E}-06$ & 4.49E-05 & $1.62 \mathrm{E}-05$ & $2.13 \mathrm{E}-05$ \\
\hline $\mathrm{Y}$ & $3.51 \mathrm{E}-06$ & $6.66 \mathrm{E}-06$ & $9.53 \mathrm{E}-06$ & $6.82 \mathrm{E}-06$ \\
\hline $\mathrm{Zn}$ & $9.43 \mathrm{E}-04$ & $5.20 \mathrm{E}-04$ & $2.35 \mathrm{E}-04$ & $8.35 \mathrm{E}-04$ \\
\hline \multirow[t]{2}{*}{$\mathrm{Zr}$} & $5.68 \mathrm{E}-05$ & $3.18 \mathrm{E}-03$ & 8.97E-03 & $1.75 \mathrm{E}-03$ \\
\hline & $\mathrm{g} /$ liter & $\mathrm{g} /$ liter & $\mathrm{g} /$ liter & $\mathrm{g} /$ liter \\
\hline TOC & 0.20 & 2.24 & 0.49 & 0.51 \\
\hline SBW Solids & 4.8 & 53.2 & 35.9 & 39.0 \\
\hline \multirow[t]{2}{*}{ SG } & 1.20 & 1.19 & 1.21 & 1.28 \\
\hline & $\mathrm{Ci} /$ liter & $\mathrm{Ci} /$ liter & $\mathrm{Ci} /$ liter & $\mathrm{Ci} /$ liter \\
\hline Ra-226 & $4.05 \mathrm{E}-12$ & 7.69E-12 & $1.10 \mathrm{E}-11$ & $7.87 \mathrm{E}-12$ \\
\hline Ac-227 & $1.91 \mathrm{E}-11$ & $3.62 \mathrm{E}-11$ & $5.18 \mathrm{E}-11$ & $3.70 \mathrm{E}-11$ \\
\hline Th-228 & $1.58 \mathrm{E}-09$ & $3.00 \mathrm{E}-09$ & 4.30E-09 & $3.07 \mathrm{E}-09$ \\
\hline Th-229 & $9.38 \mathrm{E}-14$ & $1.78 \mathrm{E}-13$ & $2.55 \mathrm{E}-13$ & $1.82 \mathrm{E}-13$ \\
\hline Th-230 & $4.06 \mathrm{E}-10$ & 7.72E-10 & 1.10E-09 & $7.90 \mathrm{E}-10$ \\
\hline Th-232 & $3.50 \mathrm{E}-16$ & $6.65 \mathrm{E}-16$ & $9.51 \mathrm{E}-16$ & $6.80 \mathrm{E}-16$ \\
\hline Th-234 & $1.02 \mathrm{E}-08$ & $1.94 \mathrm{E}-08$ & $2.78 \mathrm{E}-08$ & $1.99 \mathrm{E}-08$ \\
\hline $\mathrm{Pa}-231$ & $4.41 \mathrm{E}-11$ & $8.38 \mathrm{E}-11$ & $1.20 \mathrm{E}-10$ & $8.58 \mathrm{E}-11$ \\
\hline $\mathrm{Pa}-233$ & $1.45 \mathrm{E}-06$ & $2.75 \mathrm{E}-06$ & $3.94 \mathrm{E}-06$ & $2.82 \mathrm{E}-06$ \\
\hline U-232 & $9.82 \mathrm{E}-10$ & $1.87 \mathrm{E}-09$ & 2.67E-09 & $1.91 \mathrm{E}-09$ \\
\hline U-233 & $3.95 \mathrm{E}-11$ & $7.50 \mathrm{E}-11$ & $1.07 \mathrm{E}-10$ & $7.68 \mathrm{E}-11$ \\
\hline U-234 & $1.02 \mathrm{E}-06$ & $1.07 \mathrm{E}-06$ & $1.03 \mathrm{E}-06$ & $1.46 \mathrm{E}-06$ \\
\hline U-235 & $3.76 \mathrm{E}-08$ & $3.52 \mathrm{E}-08$ & $3.04 \mathrm{E}-08$ & 4.98E-08 \\
\hline U-236 & $5.56 \mathrm{E}-08$ & 4.83E-08 & 4.32E-08 & $6.52 \mathrm{E}-08$ \\
\hline U-237 & $3.18 \mathrm{E}-09$ & $6.04 \mathrm{E}-09$ & 8.64E-09 & $6.18 \mathrm{E}-09$ \\
\hline U-238 & $2.23 \mathrm{E}-08$ & 3.19E-08 & 3.79E-08 & $3.87 \mathrm{E}-08$ \\
\hline Np-236 & $1.52 \mathrm{E}-12$ & $2.88 \mathrm{E}-12$ & $4.12 \mathrm{E}-12$ & $2.95 \mathrm{E}-12$ \\
\hline Np-237 & $1.16 \mathrm{E}-06$ & $1.89 \mathrm{E}-06$ & $3.57 \mathrm{E}-06$ & $9.20 \mathrm{E}-07$ \\
\hline Np-239 & $1.06 \mathrm{E}-08$ & $2.01 \mathrm{E}-08$ & $2.88 \mathrm{E}-08$ & $2.06 \mathrm{E}-08$ \\
\hline $\mathrm{Pu}-236$ & $1.35 \mathrm{E}-09$ & $2.57 \mathrm{E}-09$ & $3.68 \mathrm{E}-09$ & 2.63E-09 \\
\hline $\mathrm{Pu}-238$ & $5.43 \mathrm{E}-04$ & 4.31E-04 & 5.39E-04 & $3.80 \mathrm{E}-04$ \\
\hline $\mathrm{Pu}-239$ & $7.87 \mathrm{E}-05$ & $5.52 \mathrm{E}-05$ & $7.11 \mathrm{E}-05$ & 4.40E-05 \\
\hline
\end{tabular}


Table 23. (Continued.)

\begin{tabular}{|c|c|c|c|c|}
\hline & $\begin{array}{l}\text { WM-180 } \\
\text { Ci/liter }\end{array}$ & $\begin{array}{l}\text { WM-187 } \\
\text { Ci/liter }\end{array}$ & $\begin{array}{l}\text { WM-188 } \\
\text { Ci/liter }\end{array}$ & $\begin{array}{l}\text { WM-189 } \\
\text { Ci/liter }\end{array}$ \\
\hline $\mathrm{Pu}-240$ & 5.01E-06 & $9.45 \mathrm{E}-06$ & $1.35 \mathrm{E}-05$ & $9.70 \mathrm{E}-06$ \\
\hline $\mathrm{Pu}-241$ & $1.30 \mathrm{E}-04$ & $4.32 \mathrm{E}-03$ & $1.76 \mathrm{E}-03$ & $1.02 \mathrm{E}-02$ \\
\hline $\mathrm{Pu}-242$ & 3.91E-09 & $7.66 \mathrm{E}-09$ & $1.10 \mathrm{E}-08$ & 7.71E-09 \\
\hline $\mathrm{Pu}-244$ & $3.35 \mathrm{E}-16$ & $6.36 \mathrm{E}-16$ & $9.09 \mathrm{E}-16$ & $6.50 \mathrm{E}-16$ \\
\hline Am-241 & $6.73 \mathrm{E}-05$ & $6.14 \mathrm{E}-05$ & $7.07 \mathrm{E}-05$ & $6.64 \mathrm{E}-05$ \\
\hline Am-242m & $7.51 \mathrm{E}-09$ & $1.43 \mathrm{E}-08$ & $2.04 \mathrm{E}-08$ & $1.46 \mathrm{E}-08$ \\
\hline Am-243 & $1.06 \mathrm{E}-08$ & $2.01 \mathrm{E}-08$ & $2.88 \mathrm{E}-08$ & $2.06 \mathrm{E}-08$ \\
\hline $\mathrm{Cm}-242$ & 6.19E-09 & $1.72 \mathrm{E}-08$ & $1.87 \mathrm{E}-08$ & $2.53 \mathrm{E}-08$ \\
\hline $\mathrm{Cm}-243$ & $1.40 \mathrm{E}-08$ & $2.67 \mathrm{E}-08$ & $3.82 \mathrm{E}-08$ & $2.73 \mathrm{E}-08$ \\
\hline $\mathrm{Cm}-244$ & 8.70E-07 & $1.44 \mathrm{E}-06$ & $2.29 \mathrm{E}-06$ & $1.16 \mathrm{E}-06$ \\
\hline $\mathrm{Cm}-245$ & $1.47 \mathrm{E}-10$ & $2.80 \mathrm{E}-10$ & $4.01 \mathrm{E}-10$ & $2.87 \mathrm{E}-10$ \\
\hline $\mathrm{Cm}-246$ & $9.71 \mathrm{E}-12$ & $1.85 \mathrm{E}-11$ & $2.64 \mathrm{E}-11$ & $1.89 \mathrm{E}-11$ \\
\hline $\mathrm{H}-3$ & $1.73 \mathrm{E}-05$ & $1.24 \mathrm{E}-05$ & $1.57 \mathrm{E}-05$ & $9.92 \mathrm{E}-06$ \\
\hline Be-10 & $1.48 \mathrm{E}-12$ & $2.82 \mathrm{E}-12$ & $4.03 \mathrm{E}-12$ & $2.88 \mathrm{E}-12$ \\
\hline C-14 & $5.93 \mathrm{E}-11$ & $1.02 \mathrm{E}-10$ & $1.39 \mathrm{E}-10$ & $1.11 \mathrm{E}-10$ \\
\hline Se-79 & $2.16 \mathrm{E}-07$ & 4.10E-07 & $5.86 \mathrm{E}-07$ & 4.19E-07 \\
\hline $\mathrm{Rb}-87$ & $1.45 \mathrm{E}-11$ & $2.75 \mathrm{E}-11$ & $3.93 \mathrm{E}-11$ & $2.81 \mathrm{E}-11$ \\
\hline Sr-90 & $1.93 \mathrm{E}-02$ & $3.79 \mathrm{E}-02$ & $5.50 \mathrm{E}-02$ & $3.80 \mathrm{E}-02$ \\
\hline$Y-90$ & $1.93 \mathrm{E}-02$ & $3.79 \mathrm{E}-02$ & $5.50 \mathrm{E}-02$ & $3.80 \mathrm{E}-02$ \\
\hline Zr-93 & $1.09 \mathrm{E}-06$ & $2.08 \mathrm{E}-06$ & $2.97 \mathrm{E}-06$ & $2.13 \mathrm{E}-06$ \\
\hline $\mathrm{Nb}-93 \mathrm{~m}$ & $8.43 \mathrm{E}-07$ & $1.60 \mathrm{E}-06$ & $2.29 \mathrm{E}-06$ & $1.64 \mathrm{E}-06$ \\
\hline $\mathrm{Nb}-94$ & $5.63 \mathrm{E}-07$ & $1.07 \mathrm{E}-06$ & $1.53 \mathrm{E}-06$ & $1.09 \mathrm{E}-06$ \\
\hline Tc-98 & $1.27 \mathrm{E}-12$ & $2.42 \mathrm{E}-12$ & $3.46 \mathrm{E}-12$ & $2.48 \mathrm{E}-12$ \\
\hline Tc-99 & 8.93E-06 & $1.03 \mathrm{E}-05$ & $1.41 \mathrm{E}-05$ & $9.74 \mathrm{E}-06$ \\
\hline Ru-106 & 4.59E-07 & $1.36 \mathrm{E}-06$ & $2.23 \mathrm{E}-06$ & $1.09 \mathrm{E}-06$ \\
\hline Rh-102 & $4.26 \mathrm{E}-10$ & $8.09 \mathrm{E}-10$ & $1.16 \mathrm{E}-09$ & $8.28 \mathrm{E}-10$ \\
\hline Rh-106 & $4.59 \mathrm{E}-07$ & $1.36 \mathrm{E}-06$ & $2.23 \mathrm{E}-06$ & $1.09 \mathrm{E}-06$ \\
\hline Pd-107 & $8.16 \mathrm{E}-09$ & $1.55 \mathrm{E}-08$ & $2.22 \mathrm{E}-08$ & $1.59 \mathrm{E}-08$ \\
\hline Cd-113m & $1.64 \mathrm{E}-06$ & $3.12 \mathrm{E}-06$ & $4.46 \mathrm{E}-06$ & $3.19 \mathrm{E}-06$ \\
\hline In-115 & 4.97E-17 & $9.45 \mathrm{E}-17$ & $1.35 \mathrm{E}-16$ & $9.67 \mathrm{E}-17$ \\
\hline Sn-121m & $3.30 \mathrm{E}-08$ & $6.27 \mathrm{E}-08$ & 8.98E-08 & $6.42 \mathrm{E}-08$ \\
\hline Sn-126 & $2.03 \mathrm{E}-07$ & $3.85 \mathrm{E}-07$ & $5.52 \mathrm{E}-07$ & $3.95 \mathrm{E}-07$ \\
\hline $\mathrm{Sb}-125$ & $6.38 \mathrm{E}-06$ & $1.29 \mathrm{E}-05$ & $1.87 \mathrm{E}-05$ & $1.28 \mathrm{E}-05$ \\
\hline $\mathrm{Sb}-126$ & $2.84 \mathrm{E}-08$ & $5.40 \mathrm{E}-08$ & $7.72 \mathrm{E}-08$ & $5.52 \mathrm{E}-08$ \\
\hline Te-123 & $1.89 \mathrm{E}-19$ & $3.60 \mathrm{E}-19$ & $5.15 \mathrm{E}-19$ & $3.68 \mathrm{E}-19$ \\
\hline Te-125m & $1.56 \mathrm{E}-06$ & $2.96 \mathrm{E}-06$ & $4.23 \mathrm{E}-06$ & $3.03 \mathrm{E}-06$ \\
\hline I-129 & $2.28 \mathrm{E}-08$ & 4.88E-08 & $7.06 \mathrm{E}-08$ & 5.09E-08 \\
\hline Cs-134 & $5.10 \mathrm{E}-06$ & 4.13E-05 & $6.65 \mathrm{E}-05$ & $4.10 \mathrm{E}-05$ \\
\hline Cs-135 & $4.25 \mathrm{E}-07$ & $8.07 \mathrm{E}-07$ & $1.15 \mathrm{E}-06$ & $8.26 \mathrm{E}-07$ \\
\hline Cs-137 & 2.49E-02 & 4.73E-02 & $6.77 \mathrm{E}-02$ & 4.84E-02 \\
\hline Ba-137m & $2.36 \mathrm{E}-02$ & $4.48 \mathrm{E}-02$ & $6.41 \mathrm{E}-02$ & $4.58 \mathrm{E}-02$ \\
\hline La-138 & $9.43 \mathrm{E}-17$ & $1.79 \mathrm{E}-16$ & $2.56 \mathrm{E}-16$ & $1.83 \mathrm{E}-16$ \\
\hline Ce-142 & $1.48 \mathrm{E}-11$ & $2.81 \mathrm{E}-11$ & $4.01 \mathrm{E}-11$ & $2.87 \mathrm{E}-11$ \\
\hline Ce-144 & $3.10 \mathrm{E}-07$ & $8.55 \mathrm{E}-07$ & $1.38 \mathrm{E}-06$ & $7.11 \mathrm{E}-07$ \\
\hline $\operatorname{Pr}-144 m$ & 3.71E-09 & $7.06 \mathrm{E}-09$ & $1.01 \mathrm{E}-08$ & 7.22E-09 \\
\hline Pr-144 & $3.10 \mathrm{E}-07$ & $5.88 \mathrm{E}-07$ & $8.41 \mathrm{E}-07$ & $6.02 \mathrm{E}-07$ \\
\hline Nd-144 & $7.94 \mathrm{E}-16$ & $1.51 \mathrm{E}-15$ & $2.16 \mathrm{E}-15$ & $1.54 \mathrm{E}-15$ \\
\hline Pm-146 & $2.51 \mathrm{E}-08$ & 4.78E-08 & $6.83 \mathrm{E}-08$ & 4.89E-08 \\
\hline Pm-147 & $8.41 \mathrm{E}-05$ & $1.60 \mathrm{E}-04$ & $2.29 \mathrm{E}-04$ & $1.64 \mathrm{E}-04$ \\
\hline Sm-146 & $1.36 \mathrm{E}-13$ & $2.59 \mathrm{E}-13$ & $3.70 \mathrm{E}-13$ & $2.65 \mathrm{E}-13$ \\
\hline
\end{tabular}


Table 23. (Continued.)

\begin{tabular}{lllll} 
& WM-180 & WM-187 & WM-188 & WM-189 \\
& Ci/liter & Ci/liter & Ci/liter & Ci/liter \\
Sm-147 & $3.64 \mathrm{E}-12$ & $6.91 \mathrm{E}-12$ & $9.89 \mathrm{E}-12$ & $7.07 \mathrm{E}-12$ \\
Sm-148 & $1.87 \mathrm{E}-17$ & $3.55 \mathrm{E}-17$ & $5.08 \mathrm{E}-17$ & $3.64 \mathrm{E}-17$ \\
Sm-149 & $1.66 \mathrm{E}-18$ & $3.15 \mathrm{E}-18$ & $4.51 \mathrm{E}-18$ & $3.23 \mathrm{E}-18$ \\
Sm-151 & $1.66 \mathrm{E}-04$ & $3.15 \mathrm{E}-04$ & $4.51 \mathrm{E}-04$ & $3.22 \mathrm{E}-04$ \\
Eu-150 & $7.10 \mathrm{E}-12$ & $1.35 \mathrm{E}-11$ & $1.93 \mathrm{E}-11$ & $1.38 \mathrm{E}-11$ \\
Eu-152 & $1.24 \mathrm{E}-06$ & $2.36 \mathrm{E}-06$ & $3.38 \mathrm{E}-06$ & $2.42 \mathrm{E}-06$ \\
Eu-154 & $4.42 \mathrm{E}-05$ & $1.61 \mathrm{E}-04$ & $2.35 \mathrm{E}-04$ & $1.76 \mathrm{E}-04$ \\
Eu-155 & $8.11 \mathrm{E}-05$ & $1.40 \mathrm{E}-04$ & $1.91 \mathrm{E}-04$ & $1.52 \mathrm{E}-04$ \\
Gd-152 & $7.02 \mathrm{E}-19$ & $1.33 \mathrm{E}-18$ & $1.91 \mathrm{E}-18$ & $1.37 \mathrm{E}-18$ \\
Ho-166m & $2.27 \mathrm{E}-11$ & $4.32 \mathrm{E}-11$ & $6.18 \mathrm{E}-11$ & $4.42 \mathrm{E}-11$ \\
Co-60 & $3.94 \mathrm{E}-06$ & $3.28 \mathrm{E}-05$ & $4.98 \mathrm{E}-05$ & $3.54 \mathrm{E}-05$ \\
Ni-63 & $2.34 \mathrm{E}-05$ & $3.14 \mathrm{E}-05$ & $4.27 \mathrm{E}-05$ & $3.08 \mathrm{E}-05$ \\
\hline
\end{tabular}

\subsection{Organic Species in SBW}

Estimated concentrations for total organic compounds (TOC) for various tank wastes are shown in Tables 3, 17, 18, 20, 21 and 23. This section provides additional information regarding organic species in SBW.

Recent analysis of samples of Tank WM-189 waste showed 0.092-0.3 mg/liter volatile organic compounds and 0.24-2.0 mg/liter semi-volatile organic compounds. ${ }^{4}$ The volatile and semi-volatile compounds amount to only a very small fraction of the TOC in these samples, which was measured to be 513-624 mg/liter.

Other samples of tank wastes have been analyzed for organic compounds. While these samples were from tanks that typically contained high level waste rather than SBW, the results may in general be applicable to SBW. This data is compiled in Table 24.

Table 24. Organic analyses of TFF samples

\begin{tabular}{llccc}
\hline Tank & Compound & $\begin{array}{c}\text { Concentration } \\
\mu \mathrm{g} / \text { liter }\end{array}$ & $\begin{array}{c}\text { Validation } \\
\text { Flag }\end{array}$ & Reference \\
\hline WM-182 & 2,4-Dinitrophenol & 260 & $\mathrm{~J}$ & 6 \\
WM-182 & 2,4-Dinitrophenol & 66 & $\mathrm{~J}$ & 6 \\
WM-182 & 2,4-Dinitrophenol & 52 & $\mathrm{~J}$ & 6 \\
WM-182 & 2-Butanone & 10 & $\mathrm{~J}$ & 6 \\
WM-182 & 2-Butanone & 9 & $\mathrm{~J}$ & 6 \\
WM-182 & Acetone & 110 & $\mathrm{~J}$ & 6 \\
WM-182 & Acetone & 230 & $\mathrm{E}, \mathrm{J}$ & 6 \\
WM-182 & Acetone & 120 & $\mathrm{~J}$ & 6 \\
WM-182 & Acetone & 110 & $\mathrm{~J}$ & 6 \\
WM-183 & Acetone & 49 & & 6 \\
WM-183 & Arochlor-1260 & 2.8 & $\mathrm{~J}$ & 6 \\
WM-183 & Arochlor-1260 & 2.5 & $\mathrm{~J}$ & 6 \\
WM-182 & Benzene & 5 & $\mathrm{~J}$ & 6 \\
WM-182 & Benzene & 11 & & 6 \\
WM-182 & Benzene & 84 & $\mathrm{~J}$ & 6
\end{tabular}


Table 24. (Continued.)

\begin{tabular}{|c|c|c|c|c|}
\hline Tank & Compound & $\begin{array}{c}\text { Concentration } \\
\mu \mathrm{g} / \text { liter }\end{array}$ & $\begin{array}{l}\text { Validation } \\
\text { Flag }\end{array}$ & Reference \\
\hline WM-182 & Chloroethane & 8 & $\mathrm{~J}$ & 6 \\
\hline WM-182 & Chloromethane & 34 & $\mathrm{~J}$ & 6 \\
\hline WM-182 & Chloromethane & 220 & $\mathrm{~J}$ & 6 \\
\hline WM-182 & Chloromethane & 530 & $\mathrm{E}, \mathrm{J}$ & 6 \\
\hline WM-183 & Chloromethane & 42 & $\mathrm{~J}$ & 6 \\
\hline WM-182 & Ethylbenzene & 4 & $\mathrm{~J}$ & 6 \\
\hline WM-182 & Ethylbenzene & 3 & $\mathrm{~J}$ & 6 \\
\hline WM-182 & Xylene (total meta and para) & 14 & $\mathrm{~J}$ & 6 \\
\hline WM-182 & N-nitrosodimethylamine & 31 & $\mathrm{~J}$ & 6 \\
\hline WM-182 & $\mathrm{N}$-nitrosodimethylamine & 16 & $\mathrm{~J}$ & 6 \\
\hline WM-182 & Tri-n-butylphosphate & 50 & $\mathrm{~J}$ & 6 \\
\hline WM-188 & Acetone & 12 & $\mathrm{~J}$ & 25 \\
\hline WM-188 & Acetone & 86 & & 25 \\
\hline WM-185 & Acetone & 7.7 & $\mathrm{~J}$ & 25 \\
\hline WM-185 & Acetone & 7.3 & $\mathrm{~J}$ & 25 \\
\hline WM-188 & Carbon disulfide & 6 & $\mathrm{U}$ & 25 \\
\hline WM-188 & Carbon disulfide & 8 & $\mathrm{U}$ & 25 \\
\hline WM-185 & Carbon disulfide & 4.4 & $\mathrm{U}$ & 25 \\
\hline WM-185 & Carbon disulfide & 2 & $\mathrm{U}$ & 25 \\
\hline WM-188 & 2-Butanone & 9 & U & 25 \\
\hline WM-188 & 2-Butanone & 24 & $\mathrm{U}$ & 25 \\
\hline WM-185 & 2-Butanone & 6.7 & $\mathrm{U}$ & 25 \\
\hline WM-185 & 2-Butanone & 6.4 & $\mathrm{U}$ & 25 \\
\hline WM-188 & 1,1,1-Trichloroethane & 3 & $\mathrm{U}$ & 25 \\
\hline WM-188 & 1,1,1-Trichloroethane & 8 & $\mathrm{U}$ & 25 \\
\hline WM-185 & 1,1,1-Trichloroethane & 2.2 & $\mathrm{U}$ & 25 \\
\hline WM-185 & 1,1,1-Trichloroethane & 1 & $\mathrm{U}$ & 25 \\
\hline WM-188 & Carbon tetrachloride & 3 & $\mathrm{U}$ & 25 \\
\hline WM-188 & Carbon tetrachloride & 4 & U & 25 \\
\hline WM-185 & Carbon tetrachloride & 2.2 & $\mathrm{U}$ & 25 \\
\hline WM-185 & Carbon tetrachloride & 1 & $\mathrm{U}$ & 25 \\
\hline WM-188 & Benzene & 4.6 & $\mathrm{U}$ & 25 \\
\hline WM-188 & Benzene & 8 & $\mathrm{U}$ & 25 \\
\hline WM-185 & Benzene & 2.2 & $\mathrm{U}$ & 25 \\
\hline WM-185 & Benzene & 1 & $\mathrm{U}$ & 25 \\
\hline WM-188 & 4-Methyl-2-pentanone & 9 & $\mathrm{U}$ & 25 \\
\hline WM-188 & 4-Methyl-2-pentanone & 20 & $\mathrm{U}$ & 25 \\
\hline WM-185 & 4-Methyl-2-pentanone & 6.7 & $\mathrm{U}$ & 25 \\
\hline WM-185 & 4-Methyl-2-pentanone & 3 & $\mathrm{U}$ & 25 \\
\hline WM-188 & Toluene & 3 & $\mathrm{U}$ & 25 \\
\hline WM-188 & Toluene & 12 & $\mathrm{U}$ & 25 \\
\hline WM-185 & Toluene & 2.2 & $\mathrm{U}$ & 25 \\
\hline WM-185 & Toluene & 1 & $\mathrm{U}$ & 25 \\
\hline WM-188 & Xylene (total meta and para) & 3 & $\mathrm{U}$ & 25 \\
\hline WM-188 & Xylene (total meta and para) & 4 & $\mathrm{U}$ & 25 \\
\hline WM-185 & Xylene (total meta and para) & 2.2 & U & 25 \\
\hline
\end{tabular}


Table 24. (Continued.)

\begin{tabular}{|c|c|c|c|c|}
\hline Tank & Compound & $\begin{array}{c}\text { Concentration } \\
\mu \mathrm{g} / \text { liter }\end{array}$ & $\begin{array}{c}\text { Validation } \\
\text { Flag }^{\mathrm{a}}\end{array}$ & Reference \\
\hline WM-188 & Xylene (ortho) & 3 & $\mathrm{U}$ & 25 \\
\hline WM-188 & Xylene (ortho) & 8 & $\mathrm{U}$ & 25 \\
\hline WM-185 & Xylene (ortho) & 2.2 & $\mathrm{U}$ & 25 \\
\hline WM-185 & Xylene (ortho) & 1 & $\mathrm{U}$ & 25 \\
\hline WM-188 & Triphenylester phosphoric acid & 61 & $\mathrm{~J}, \mathrm{~N}$ & 25 \\
\hline WM-188 & Unknown phthalates & 1600 & $\mathrm{~J}$ & 25 \\
\hline WM-188 & Unknown semi-volatiles & 6500 & $\mathrm{~J}$ & 25 \\
\hline WM-185 & Unknown semi-volatiles & 1100 & $\mathrm{~J}, \mathrm{~B}$ & 25 \\
\hline WM-189 & Organomercury compound & 62 & $\mathrm{~J}$ & 25 \\
\hline WM-188 & Pyridine & 26 & E & 25 \\
\hline WM-185 & Pyridine & 160 & E & 25 \\
\hline WM-188 & Phenol & 10 & $\mathrm{U}$ & 25 \\
\hline WM-185 & Phenol & 10 & $\mathrm{U}$ & 25 \\
\hline WM-188 & 2-Nitropyridine & 520 & $\mathrm{~J}, \mathrm{~N}$ & 25 \\
\hline WM-188 & Dinitrobenzene & 30 & $\mathrm{~J}$ & 25 \\
\hline WM-185 & Dinitrobenzene & 55 & $\mathrm{~J}$ & 25 \\
\hline WM-188 & Chlorinated dinitrobenzene & 32 & $\mathrm{~J}$ & 25 \\
\hline WM-188 & Bis (2-ethylhexyl) phthalate & 38 & $\mathrm{~J}, \mathrm{~N}, \mathrm{~B}$ & 25 \\
\hline WM-188 & Bis (2-ethylhexyl) phthalate & 41 & $\mathrm{~J}, \mathrm{~N}$ & 25 \\
\hline WM-189 & Dibutyl phthalate & 200 & $\mathrm{~J}, \mathrm{~N}$ & 25 \\
\hline WM-185 & Diethyl phthalate & 44 & $\mathrm{~J}, \mathrm{~N}$ & 25 \\
\hline WM-188 & Butylated hydoxytoluene & 18 & $\mathrm{~J}, \mathrm{~N}$ & 25 \\
\hline WM-188 & Tributyl phosphate & 12 & $\mathrm{~J}, \mathrm{~N}$ & 25 \\
\hline WM-185 & Tributyl phosphate & 58 & $\mathrm{~J}, \mathrm{~N}, \mathrm{~B}$ & 25 \\
\hline WM-185 & Diisopropyl ether & 36 & $\mathrm{~J}, \mathrm{~N}$ & 25 \\
\hline WM-185 & Dimethyl sulfone & 33 & $\mathrm{~J}$ & 25 \\
\hline WM-185 & Benzylquinoline & 500 & $\mathrm{~J}$ & 25 \\
\hline
\end{tabular}

Additional analysis data is available for organic compounds in waste from Tanks WM-189 and WM-185 sampled in 1999 in the NWCF blend and hold cell tanks. Analyses were performed for 68 semivolatile species; no compound was present at a concentration greater than detection limits. ${ }^{26}$

A recent study evaluated the destruction of 22 different volatile and 21 different semi-volatile organic compounds in simulated SBW. ${ }^{27}$ The surrogate was prepared with nitric acid, aluminum sulfate, calcium chloride, iron sulfate, potassium fluoride and sodium sulfate. The spiked organic compounds represented a wide range of organic classes and functional groups. Concentrations of the organic species in the simulant were measured at intervals during a 32-day period. Some of the results of this study were:

- Except for chloromethane and bromomethane, levels of all volatile organic compounds decreased over time. The most volatile species rapidly decreased, sometimes to near $0 \%$ of the initial spike concentration, even prior to the Day 1 analysis. Lower volatility volatile organic compounds (VOCs) and those with higher water solubility (like acetone, methylisobutylketone, methylene chloride, and carbon disulfide) either decreased more slowly, or showed erratic results. However they nevertheless almost always decreased to $30 \%$ or less of the initial spike concentration after 32 days. All VOCs, even those species with slower or erratic depletion rates, would be expected to be highly depleted 
from the actual SBW that has been held in storage for many years and also exposed to $100^{\circ} \mathrm{C}$ temperatures during evaporation processes. The increase in concentration seen for chloromethane and bromomethane was thought to be an artifact of the analysis method, as these compounds are products of reactions occurring on the carbon sorbent based trap used to separate the organics from the acid sample.

- Measured levels of semivolatile organic compounds (SVOCs) decreased more slowly, and in some cases were more erratic, than the VOCs. More reactive SVOCs, like those with double bonds (1,7octadiene and hexachlorobutadiene) and phenyl groups (cresol, analine, and phenol) were rapidly depleted to a concentration near zero.

- More stable SVOCs like ethers (1,4-dioxane) and water-soluble species like pyridine were depleted more slowly to a relatively stable level, and may not be highly depleted even after long time durations. Levels of some other SVOCs (like nonanoic acid and the nitrophenols) were erratic, and suggest that either (a) in some samples, recovery of these more water-soluble compounds was poor, or (b) these compounds were being formed later in the longer-duration samples.

- The VOC gas chromatography/mass spectrometer scans were evaluated to find any tentatively identified compounds that were not included in the spike compounds and that could have been reaction products of the spiked VOCs. No tentatively identified compounds were detected in appreciable amounts. Even if some reactions of spiked VOCs resulted in reaction products, these products were either (a) volatilized, or (b) too water-soluble to efficiently extract from the aqueous media to be detected.

- Some SVOC tentatively identified compounds were detected in the SVOC scans and suggest that nitration, oxidation, and chlorination reactions occurred in the samples and could occur in the SBW during storage.

\subsection{Liquid SBW Properties}

Specific gravities of the tanks wastes are given in Table 20; specific gravities for feeds to coprocessing alternatives are given in Table 23.

The viscosity of Tank WM-189 liquid was measured at $1.94 \mathrm{cP}\left(30.2^{\circ} \mathrm{C}, 60 \mathrm{rpm}\right){ }^{4}$ This viscosity value is consistent with measurements ${ }^{24}$ of samples from other tanks:

$\begin{array}{ll}\text { WM-180 } & 2.2 \mathrm{cP} \\ \text { WM-181 } & 1.8 \mathrm{cP} \\ \text { WM-182 } & 1.3 \mathrm{cP} \\ \text { WM-186 } & 1.8 \mathrm{cP} .\end{array}$

Solids in samples from the above tanks were allowed to settle prior to withdrawing a portion of the liquid for the viscosity measurements. ${ }^{24}$

In Reference 4, Batcheller reports and discusses viscosity data for the WM-189 bottom sample as received. This sample contained about $9 \mathrm{~g} /$ liter UDS. At $60 \mathrm{rpm}\left(73.4 \mathrm{sec}^{-1}\right.$ shear rate) the viscosity was $2.6 \mathrm{cP}$, while at $30 \mathrm{rpm}\left(36.7 \mathrm{sec}^{-1}\right.$ shear rate $)$ the viscosity was $2.1 \mathrm{cP}$.

Viscosity measurements for tank slurries with higher solids fractions are discussed in Section 3.3. 


\section{TANKS SOLIDS QUANTITY, COMPOSITION AND PROPERTIES}

Undissolved solids are present in Tank Farm tanks that will need to be processed either together with the liquid waste or separately. Solids from Tanks WM-182 and WM-183 have been flushed to WM187; solids from four other tanks (WM-181, WM-184, WM-185 and WM-186) are scheduled to be flushed to WM-187 by the middle of FY-2005. Estimates of the quantity, composition and properties of tank solids are given in the following sections. These estimates are needed at this time to provide a basis for SBW Treatment development studies and conceptual design activities. Additional sampling of tank solids this year and in future years will provide additional solids data to confirm and improve the estimates.

\subsection{Tank Solids Quantity}

Light Duty Utility Arm (LDUA) video evidence of the height of tank sludge layers, along with measurement of sludge samples from these tanks provides good estimates of solids quantities for three tanks. Tank WM-188 was sampled using the LDUA in $1998 ;^{5}$ and WM-182 and WM-183 in 2000 . $^{7}$ Based on the videos, the sludge layers in Tanks WM-188, WM-182 and WM-183 were estimated to be 0.25 -inch, 4 inches and 8-inches respectively. Using the history on each tank as a guide, and measurements from WM-183 samples that showed the sludge was approximately 25 vol \% solids and that the solids had a particle density of $2 \mathrm{~g} /$ liter, Poloski estimated sludge volumes ${ }^{7}$ and Tyson ${ }^{8}$ the corresponding mass of solids in the each tank in the Tank Farm. These sludge volume and mass estimates, shown in Table 25, have been widely used, since they were developed, for SBW treatment studies, ${ }^{19,21}$ the SBW Waste Incidental to Reprocessing (WIR) evaluation, ${ }^{8}$ and the basis for the radiological source term for Tank Farm safety analyses. ${ }^{17}$

Table 25. Estimated solids quantities based on LDUA samples and videos, ${ }^{5,7,8}$

\begin{tabular}{lcccc}
\hline Tank & $\begin{array}{c}\text { Sludge Height } \\
\text { (in.) }\end{array}$ & $\begin{array}{c}\text { Sludge on Walls } \\
\text { (equiv. in.) }\end{array}$ & $\begin{array}{c}\text { Total Sludge } \\
\text { (equiv. in.) }\end{array}$ & $\begin{array}{c}\text { Total Solids } \\
\text { (kg) }\end{array}$ \\
\hline WM-180 (like WM-182) & 4.00 & 0.50 & 4.5 & 10,452 \\
WM-181 (like WM-182) & 4.00 & 0.50 & 4.5 & 10,452 \\
WM-182 & 4.00 & 0.50 & 4.5 & 10,452 \\
WM-183 & 8.00 & 0.50 & 8.5 & 19,743 \\
WM-184 (like WM-182) & 4.00 & 0.50 & 4.5 & 10,452 \\
WM-185 (like WM-182) & 4.00 & 0.50 & 4.5 & 10,452 \\
WM-186 (like WM-182) & 4.00 & 0.50 & 4.5 & 10,452 \\
WM-187 (like WM-188) & 0.25 & 0.25 & 0.5 & 1,161 \\
WM-188 & 0.25 & 0.25 & 0.5 & 1,161 \\
WM-189 (like WM-188) & $\underline{0.25}$ & $\underline{0.25}$ & $\underline{0.5}$ & $\underline{1,161}$ \\
Total & 32.75 & 4.25 & 37.0 & 85,941 \\
\hline
\end{tabular}

Since the estimates listed in Table 25 were made, waste from Tanks WM-181, WM-184, WM-186 and WM-185 has been evaporated to heel level and the concentrate added to Tanks WM-188 and WM189, Tank WM-189 was sampled, and solids in Tanks WM-182 and WM-183 have been flushed to WM187. During evaporation of waste from Tank WM-186, as the waste was lowered to about the 15,000 
gallon level, severe plugging problems were experienced in instrument probes and some other lines. ${ }^{18}$ Evaporation of waste from Tanks WM-181 and WM-185, in addition to WM-186, was stopped when high undissolved solids caused plugging in instrument probes. ${ }^{b}$ The heel level of each of these three tanks when processing by evaporation was stopped was between 13,000 and 23,000 gallons. Since the estimates of sludge volume shown in Table 25 for these tanks are only about 5,000 gallons each, the solids seen in the evaporator probes suggest that there may be more solids in these tanks than originally estimated.

In March 2002 a sample from near the bottom of Tank WM-189 was taken using an existing steam jet located approximately 2 -inches off the tank bottom. The $165 \mathrm{ml}$ sample was allowed to settle for 24 hours, at which time a sludge layer of approximately $24 \mathrm{ml}$ was seen. ${ }^{4}$ In contrast, undissolved solids from a sample taken by steam jet, $\sim 3$-inches off the bottom, from Tank WM-180 were measured to be only $0.23 \mathrm{~g} /$ liter. While a direct comparison of data from these two tank samples is difficult, it appears the WM-189 sample had considerable more solids than the WM-180 sample.

Additional samples of the heel in several tanks will be taken this year and will help resolve present uncertainties in the estimates of total tank solids. However, in light of the above indications that there could be more solids than originally estimated, for development and design studies occurring in FY 2003, the following estimates are proposed for the quantity of solids that will be present in the tanks at the commencement of SBW treatment:

\begin{tabular}{lll}
\hline & Expected & Maximum \\
\hline WM-180 & $5,000 \mathrm{~kg}$ & $10,000 \mathrm{~kg}$ \\
WM-188 & $5,000 \mathrm{~kg}$ & $10,000 \mathrm{~kg}$ \\
WM-189 & $10,000 \mathrm{~kg}$ & $20,000 \mathrm{~kg}$ \\
WM-187 & $100,000 \mathrm{~kg}$ & $160,000 \mathrm{~kg}$ \\
Total & $120,000 \mathrm{~kg}$ & $200,000 \mathrm{~kg}$ \\
\hline
\end{tabular}

The basis for the above estimates is as follows:

- WM-180: The estimated maximum is consistent with the previous estimate (Table 25). The expected quantity is based on assuming 3-inches of sludge with an average solids content of 16 vol $\%^{\mathrm{c}}$ and a solids density of $2 \mathrm{~g} / \mathrm{cm}^{3}$.

- WM-187: The estimated maximum is based on the summing the volumes of heel presently in tanks that will be flushed to WM-187, and assuming a solids content of $25 \mathrm{vol} \%$ and a solids density of $2 \mathrm{~g} / \mathrm{cm}^{3}$. The expected quantity is based on the same volume of sludge and the assumption of $16 \mathrm{vol} \%$ solids $^{\mathrm{c}}$ in the sludge.

- WM-188 and WM-189: When tank WM-188 was at heel level, LDUA videos showed very little ( 1/4 inch) solids. WM-188 has since been filled will HLLWE concentrate. A sample from WM189 , which was filled with much the same evaporator concentrate, showed significantly more solids than a similar sample from WM-180. However, other high solids waste, i.e., NWCF flushes

\footnotetext{
${ }^{\mathrm{b}}$ Personal communication with Dan Griffith, October 23, 2002.

${ }^{\mathrm{c}}$ A solids content of $16 \mathrm{vol} \%$ is based on the solids content of WM-183 heel in early 1997 and also the average of WM-183 LDUA sludge sample solids content (25\%) and WM-189 sludge solids content ( $7 \%)$.
} 
and off-gas scrub, were added to WM-189 and not to WM-188. Thus Tank WM-189 should have more solids than WM-180, and WM-188 likely has less solids than WM-189. For lack of additional data, the amount of solids WM-188 was assumed to be equal to that in WM-180 and the amount in WM-189 twice the amount in WM-180. The estimated expected amount of settled solids in WM189 and the maximum amount in WM-188, $10,000 \mathrm{~kg}$, is approximately equivalent to 20,000 gallons of sludge with a solids content of $7 \mathrm{vol} \%$ and a solids density of $2 \mathrm{~g} / \mathrm{cm}^{3}$.

\subsection{Solids Composition}

For SBW Treatment Facility design studies, solids compositions are needed for the solids contained in treatment facility feeds. For separate processing scenarios, a relatively small amount of solids will be present in the SBW feeds from Tanks WM-180, WM-188 and WM-189. These entrained solids, often called "UDS," will be present in varying but small concentrations in the highly acidic SBW. In contrast, the waste feed from WM-187 will be received at the treatment facility in a dilute acid/salt solution and at a relatively high solids concentration. For separate processing alternatives, solids that have settled to the bottom of Tanks WM-180, WM-188 and WM-189 would be flushed with water to the SBW Treatment Facility after the liquid has been treated. Specie concentrations of primary importance are cesium isotopes in the smallest particle size range. Other chemical species are of interest primarily to prepare adequate surrogates for equipment performance verification tests. Composition of the settled solids is needed primarily to ensure meeting transportation and disposal requirements for these solids in final waste form.

For treatment alternatives in which solids are co-processed with liquid SBW, prior to treatment solids from WM-187 will be mixed with the highly acidic waste in the other tanks. According to the present mixing scenario, the treatment facility will process waste from Tanks WM-188, WM-189 and WM-187 with solids of very similar composition because the majority of the solids in each of these will have come from solids mixed in and transferred from WM-187. Solids in Tank WM-180 will be of lower concentration and of different composition.

The following sections discuss results of tank solids analyses and then suggest how to relate the analysis data to the solids in SBW Treatment Facility feeds.

Table 26 shows the results of analyses of samples taken by the LDUA from Tanks WM-182, WM183 , and WM-188.

Table 26. Analyses of solids samples from Tanks WM-182, WM-183, and WM-188.,

\begin{tabular}{|c|c|c|c|c|c|c|c|}
\hline & $\begin{array}{c}\text { WM-182 } \\
\mathrm{mg} / \mathrm{kg}\end{array}$ & $\begin{array}{c}\text { WM-183 } \\
\mathrm{mg} / \mathrm{kg}\end{array}$ & $\begin{array}{c}\text { WM-188 } \\
\mathrm{mg} / \mathrm{kg}\end{array}$ & & $\begin{array}{c}\mathrm{WM}-182 \\
\mathrm{mg} / \mathrm{kg}\end{array}$ & $\begin{array}{c}\mathrm{WM}-183 \\
\mathrm{mg} / \mathrm{kg}\end{array}$ & $\begin{array}{c}\mathrm{WM}-188 \\
\mathrm{mg} / \mathrm{kg}\end{array}$ \\
\hline$\overline{\mathrm{Al}}$ & 21,880 & 24,911 & 35,406 & $\mathrm{Sr}$ & $<9$ & 11 & \\
\hline $\mathrm{Sb}$ & $<14$ & 32 & $<34$ & $\mathrm{SO}_{4}$ & 33,240 & 13,647 & \\
\hline As & 281 & 56 & 351 & $\mathrm{~S}$ & 8,743 & 2,849 & \\
\hline $\mathrm{Ba}$ & 127 & 24 & 12,542 & $\mathrm{Tc}$ & & 0 & \\
\hline $\mathrm{Be}$ & $<1$ & $<0.91$ & 0.2 & $\mathrm{Tl}$ & $<17$ & $<14$ & $<783$ \\
\hline B & 150 & 182 & $<482$ & $\mathrm{Sn}$ & 4,072 & 1,466 & \\
\hline $\mathrm{Cd}$ & 325 & 142 & 1,189 & $\mathrm{Ti}$ & 650 & 711 & \\
\hline $\mathrm{Ca}$ & 1,765 & 1,868 & 5,630 & $\mathrm{U}$ & $<46$ & 0.193 & \\
\hline $\mathrm{Ce}$ & $<21$ & 20 & & $\mathrm{~V}$ & 13 & 11 & 6 \\
\hline $\mathrm{Cs}$ & 42 & 9 & $<128$ & $\mathrm{Zn}$ & 179 & 148 & 126 \\
\hline $\mathrm{Cl}$ & 2,015 & 1,308 & & $\mathrm{Zr}$ & 101,470 & $\underline{34,867}$ & 70,600 \\
\hline $\mathrm{Cr}$ & 552 & 949 & 1,341 & Total & 437,827 & 486,039 & 165,675 \\
\hline $\mathrm{Co}$ & $<9$ & 9 & 9 & TOC & & & $<1215$ \\
\hline
\end{tabular}


Table 26. (continued).

\begin{tabular}{|c|c|c|c|c|c|c|c|}
\hline & $\begin{array}{c}\text { WM-182 } \\
\mathrm{mg} / \mathrm{kg}\end{array}$ & $\begin{array}{c}\text { WM-183 } \\
\mathrm{mg} / \mathrm{kg}\end{array}$ & $\begin{array}{c}\text { WM-188 } \\
\mathrm{mg} / \mathrm{kg}\end{array}$ & & $\begin{array}{c}\text { WM-182 } \\
\mathrm{mg} / \mathrm{kg}\end{array}$ & $\begin{array}{c}\text { WM-183 } \\
\mathrm{mg} / \mathrm{kg}\end{array}$ & $\begin{array}{c}\text { WM-188 } \\
\mathrm{mg} / \mathrm{kg}\end{array}$ \\
\hline $\mathrm{Cu}$ & 298 & 166 & & & & & \\
\hline $\mathrm{F}$ & 14,800 & 4,373 & & & $\underline{\mathrm{mCi} / \mathrm{g}}$ & $\underline{\mathrm{mCi} / \mathrm{g}}$ & $\underline{\mathrm{mCi} / \mathrm{g}}$ \\
\hline $\mathrm{Gd}$ & 53 & 170 & & Am-241 & $8.46 \mathrm{E}-04$ & $2.45 \mathrm{E}-04$ & $2.11 \mathrm{E}-04$ \\
\hline $\mathrm{Fe}$ & 4,476 & 17,967 & 5,769 & $\mathrm{Sb}-125$ & $5.77 \mathrm{E}-02$ & $2.90 \mathrm{E}-03$ & $1.12 \mathrm{E}-02$ \\
\hline $\mathrm{Pb}$ & 369 & 274 & 647 & Cs-134 & 6.64E-03 & $5.89 \mathrm{E}-04$ & 7.97E-03 \\
\hline $\mathrm{Li}$ & 6 & 4 & & Cs-137 & $4.50 \mathrm{E}+00$ & $8.68 \mathrm{E}-01$ & $2.44 \mathrm{E}+00$ \\
\hline $\mathrm{Mg}$ & 410 & 434 & & Co-60 & $2.14 \mathrm{E}-04$ & & $6.30 \mathrm{E}-04$ \\
\hline $\mathrm{Mn}$ & 565 & 740 & 758 & $\mathrm{Cm}-244$ & 2.84E-06 & & \\
\hline $\mathrm{Hg}$ & 310 & 324 & 1,566 & Eu-154 & $1.48 \mathrm{E}-03$ & 7.56E-04 & $5.43 \mathrm{E}-04$ \\
\hline Mo & 2,495 & 694 & 2,770 & I-129 & $<2.22 \mathrm{E}-07$ & $<9.03 \mathrm{E}-08$ & $<1.53 \mathrm{E}-03$ \\
\hline $\mathrm{Ni}$ & 309 & 417 & 427 & Np-237 & $1.68 \mathrm{E}-06$ & $1.76 \mathrm{E}-06$ & $2.85 \mathrm{E}-06$ \\
\hline $\mathrm{Nb}$ & 1,279 & 623 & 5,370 & $\mathrm{Nb}-95$ & & & $3.68 \mathrm{E}-03$ \\
\hline $\mathrm{NO}_{3}$ & 70,720 & 174,955 & & $\mathrm{Pu}-238$ & $1.93 \mathrm{E}-02$ & $4.00 \mathrm{E}-03$ & $7.56 \mathrm{E}-03$ \\
\hline $\mathrm{Pd}$ & 5,766 & 1,444 & & $\mathrm{Pu}-239$ & $1.47 \mathrm{E}-03$ & $1.25 \mathrm{E}-03$ & 4.30E-04 \\
\hline $\mathrm{PO}_{4}$ & 68,410 & 125,612 & & Sr-90 & 2.29E-01 & $1.82 \mathrm{E}-01$ & $5.46 \mathrm{E}+00$ \\
\hline $\mathrm{P}$ & 9,586 & 4,607 & 17,700 & Tc-99 & $2.63 \mathrm{E}-03$ & $3.29 \mathrm{E}-05$ & 4.49E-03 \\
\hline K & 7,050 & 10,900 & & H-3 & $1.15 \mathrm{E}-05$ & & \\
\hline $\mathrm{Ru}$ & 829 & 2,126 & $<313$ & U-234 & $<2.40 \mathrm{E}-06$ & $3.30 \mathrm{E}-06$ & $<2.10 \mathrm{E}-05$ \\
\hline $\mathrm{Se}$ & 91 & $<13$ & $<1,720$ & U-235 & $2.61 \mathrm{E}-07$ & 9.29E-08 & $1.97 \mathrm{E}-07$ \\
\hline $\mathrm{Si}$ & 43,920 & 35,344 & & U-236 & $3.05 \mathrm{E}-07$ & $<3.40 \mathrm{E}-08$ & $<2.20 \mathrm{E}-07$ \\
\hline $\mathrm{Ag}$ & 65 & 220 & 9 & U-238 & $3.83 \mathrm{E}-08$ & $6.91 \mathrm{E}-08$ & $1.18 \mathrm{E}-07$ \\
\hline $\mathrm{Na}$ & 30,400 & 21,400 & & & & & \\
\hline
\end{tabular}

The amount of hydrated water in the LDUA sample of WM-188 solids was measured by screening the solids, washing them with 0.1 molar $\mathrm{HNO}_{3}$, then air drying, adding water to rehydrate the solids, and comparing the mass of rehydrated solids with the mass of dried solids. Three WM-188 samples gave results of $55.1 \%, 56.8 \%$, and $59.1 \%$ water in the solids. These results suggest that the mass not identified by species in Table 25 ( $56 \%$ for WM-182 solids, $51 \%$ for WM-183 solids) is largely water. A portion of the unidentified mass could also be due to oxygen bound in oxides.

The analyses shown in Table 26 for WM-182 and WM-183 are for air-dried solids. Based on data for the WM-183 LDUA sample, Harbour et $\mathrm{al}^{15}$ calculated that $30 \%$ of the mass of the air dried solids resulted from crystallization of dissolved solids during drying. Using the analyses of liquid from these two tanks and assuming the same fraction of dissolved solids in the WM-182 sample, Harbour also calculated a composition for the insoluble solids only. Starting with the compositions that Harbour calculated for WM-182 and WM-183, the amount of oxygen as oxide was calculated by charge balance and the resulting composition is shown in Table 27. The normalized composition shown in Table 27 does not include water of hydration.

Estimated radionuclide concentrations are also shown in Table 27. Swenson ${ }^{17}$ has reported concentrations for an expanded slate of radionuclides derived from the LDUA sample analysis data. The radionuclide concentrations shown in Table 27 were derived from Swenson's estimates by decaying activities to January 1, 2003 and adjusting for the dissolved solids that crystallized while drying the sample. Table 28 shows the dissolved solids adjustment factors. A default adjustment factor of zero was assumed for tritium and of 1 for species for which there was no analysis data.

An inadequate amount of solids was present in the WM-188 LDUA sample to perform analyses for some of the major chemical species expected in the solids. Swenson ${ }^{17}$ has estimated concentrations of 
additional radionuclides for these solids. While additional waste has been added to Tank WM-188 since the LDUA sample was taken that potentially changes the solids composition, the estimate from the LDUA sample provides data that can contribute to defining a range of composition for the solids from the different tanks. Table 29 shows estimated radionuclide concentrations of WM-188 solids, calculated by decaying Swenson's estimates to January 2003 and adjusting for crystallized solids from interstitial solution according to the factors shown in Table 28.

Table 27. Adjusted solids composition of WM-182 and WM-183.

\begin{tabular}{|c|c|c|c|c|c|c|c|}
\hline & WM-182 & WM-183 & Average & & WM-182 & WM-183 & Average \\
\hline & Mol Frac & Mol Frac & Mol Frac & & $\mathrm{Ci} / \mathrm{kg}$ & $\mathrm{Ci} / \mathrm{kg}$ & $\mathrm{Ci} / \mathrm{kg}$ \\
\hline $\mathrm{Al}$ & $3.58 \%$ & $4.56 \%$ & $4.07 \%$ & Rh-106 & $7.4 \mathrm{E}-06$ & $1.5 \mathrm{E}-05$ & $1.1 \mathrm{E}-05$ \\
\hline $\mathrm{Sb}$ & $0.001 \%$ & $0.004 \%$ & $0.003 \%$ & Sn-126 & $3.2 \mathrm{E}-06$ & $6.8 \mathrm{E}-06$ & $5.0 \mathrm{E}-06$ \\
\hline As & $0.03 \%$ & $0.01 \%$ & $0.02 \%$ & Sb-125 & $3.2 \mathrm{E}-02$ & $1.7 \mathrm{E}-03$ & $1.7 \mathrm{E}-02$ \\
\hline B & $0.07 \%$ & $0.06 \%$ & $0.06 \%$ & I-129 & $4.2 \mathrm{E}-07$ & 8.7E-07 & $6.5 \mathrm{E}-07$ \\
\hline $\mathrm{Ba}$ & $0.008 \%$ & $0.002 \%$ & $0.005 \%$ & Cs-134 & $2.3 \mathrm{E}-03$ & $2.2 \mathrm{E}-04$ & $1.3 \mathrm{E}-03$ \\
\hline $\mathrm{Ca}$ & $0.23 \%$ & $0.13 \%$ & $0.18 \%$ & Cs-135 & 5.9E-06 & $1.2 \mathrm{E}-05$ & $9.1 \mathrm{E}-06$ \\
\hline $\mathrm{Cd}$ & $0.02 \%$ & $0.00 \%$ & $0.01 \%$ & Cs-137 & 3.3E-01 & $6.9 \mathrm{E}-01$ & $5.1 \mathrm{E}-01$ \\
\hline $\mathrm{Cl}$ & $0.41 \%$ & $0.39 \%$ & $0.40 \%$ & Ba-137m & $3.2 \mathrm{E}-01$ & $6.6 \mathrm{E}-01$ & 4.9E-01 \\
\hline $\mathrm{Cr}$ & $0.07 \%$ & $0.11 \%$ & $0.09 \%$ & Ce-144 & $5.0 \mathrm{E}-06$ & $1.0 \mathrm{E}-05$ & $7.8 \mathrm{E}-06$ \\
\hline $\mathrm{F}$ & $6.78 \%$ & $2.74 \%$ & $4.76 \%$ & Pr-144 & $5.0 \mathrm{E}-06$ & $1.0 \mathrm{E}-05$ & $7.8 \mathrm{E}-06$ \\
\hline $\mathrm{Fe}$ & $0.59 \%$ & $4.24 \%$ & $2.42 \%$ & Pm-147 & $1.3 \mathrm{E}-03$ & $2.8 \mathrm{E}-03$ & $2.1 \mathrm{E}-03$ \\
\hline $\mathrm{Pb}$ & $0.012 \%$ & $0.005 \%$ & $0.008 \%$ & Sm-151 & $2.7 \mathrm{E}-03$ & $5.5 \mathrm{E}-03$ & 4.1E-03 \\
\hline $\mathrm{Hg}$ & $0.003 \%$ & $0.000 \%$ & $0.001 \%$ & Eu-152 & $1.2 \mathrm{E}-05$ & $2.4 \mathrm{E}-05$ & $1.8 \mathrm{E}-05$ \\
\hline $\mathrm{Mg}$ & $0.11 \%$ & $0.10 \%$ & $0.10 \%$ & Eu-154 & 7.2E-04 & $3.7 \mathrm{E}-04$ & $5.5 \mathrm{E}-04$ \\
\hline $\mathrm{Mn}$ & $0.04 \%$ & $0.02 \%$ & $0.03 \%$ & Eu-155 & $7.5 \mathrm{E}-04$ & $1.6 \mathrm{E}-03$ & $1.2 \mathrm{E}-03$ \\
\hline Mo & $0.24 \%$ & $0.10 \%$ & $0.17 \%$ & Th-230 & $6.3 \mathrm{E}-09$ & $1.3 \mathrm{E}-08$ & $9.7 \mathrm{E}-09$ \\
\hline $\mathrm{Nb}$ & $0.13 \%$ & $0.10 \%$ & $0.12 \%$ & U-232 & $1.3 \mathrm{E}-08$ & 2.7E-08 & $2.0 \mathrm{E}-08$ \\
\hline $\mathrm{Ni}$ & $0.04 \%$ & $0.03 \%$ & $0.03 \%$ & U-233 & $2.2 \mathrm{E}-10$ & $4.6 \mathrm{E}-10$ & $3.4 \mathrm{E}-10$ \\
\hline NO3 & $0.00 \%$ & $0.00 \%$ & $0.00 \%$ & U-234 & $5.5 \mathrm{E}-06$ & $2.9 \mathrm{E}-06$ & $4.2 \mathrm{E}-06$ \\
\hline PO4 & $6.67 \%$ & $20.61 \%$ & $13.64 \%$ & U-235 & $2.3 \mathrm{E}-07$ & $1.5 \mathrm{E}-07$ & $1.9 \mathrm{E}-07$ \\
\hline $\mathrm{K}$ & $0.98 \%$ & $2.78 \%$ & $1.88 \%$ & U-236 & 2.7E-07 & 4.7E-07 & $3.7 \mathrm{E}-07$ \\
\hline SO4 & $2.98 \%$ & $1.70 \%$ & $2.34 \%$ & U-237 & $4.4 \mathrm{E}-65$ & $9.2 \mathrm{E}-65$ & $6.8 \mathrm{E}-65$ \\
\hline $\mathrm{Se}$ & $0.01 \%$ & $0.00 \%$ & $0.01 \%$ & U-238 & $2.2 \mathrm{E}-08$ & $3.6 \mathrm{E}-08$ & $2.9 \mathrm{E}-08$ \\
\hline $\mathrm{Si}$ & $14.45 \%$ & $19.56 \%$ & $17.00 \%$ & $\mathrm{~Np}-237$ & $1.7 \mathrm{E}-06$ & $1.8 \mathrm{E}-06$ & $1.7 \mathrm{E}-06$ \\
\hline $\mathrm{Ag}$ & $0.01 \%$ & $0.03 \%$ & $0.02 \%$ & $\mathrm{Pu}-236$ & $1.8 \mathrm{E}-08$ & $3.7 \mathrm{E}-08$ & $2.7 \mathrm{E}-08$ \\
\hline $\mathrm{Na}$ & $6.41 \%$ & $1.96 \%$ & $4.18 \%$ & $\mathrm{Pu}-238$ & $1.4 \mathrm{E}-02$ & $2.9 \mathrm{E}-03$ & $8.6 \mathrm{E}-03$ \\
\hline $\mathrm{Sn}$ & $0.32 \%$ & $0.19 \%$ & $0.26 \%$ & $\mathrm{Pu}-239$ & $1.2 \mathrm{E}-03$ & $1.0 \mathrm{E}-03$ & $1.1 \mathrm{E}-03$ \\
\hline $\mathrm{Ti}$ & $0.13 \%$ & $0.23 \%$ & $0.18 \%$ & $\mathrm{Pu}-240$ & $6.9 \mathrm{E}-05$ & $1.4 \mathrm{E}-04$ & $1.1 \mathrm{E}-04$ \\
\hline $\mathrm{Zn}$ & $0.02 \%$ & $0.01 \%$ & $0.01 \%$ & $\mathrm{Pu}-241$ & $1.1 \mathrm{E}-02$ & $2.2 \mathrm{E}-03$ & $6.5 \mathrm{E}-03$ \\
\hline $\mathrm{Zr}$ & $10.21 \%$ & $5.93 \%$ & $8.07 \%$ & $\mathrm{Pu}-242$ & $5.2 \mathrm{E}-08$ & $1.1 \mathrm{E}-07$ & $8.0 \mathrm{E}-08$ \\
\hline Oxygen from oxides & $45.46 \%$ & $34.39 \%$ & $39.92 \%$ & $\mathrm{Pu}-244$ & $4.4 \mathrm{E}-15$ & $9.2 \mathrm{E}-15$ & $6.8 \mathrm{E}-15$ \\
\hline \multirow[t]{3}{*}{ Total } & $100.00 \%$ & $100.00 \%$ & $100.00 \%$ & Am-241 & $6.5 \mathrm{E}-04$ & $1.9 \mathrm{E}-04$ & $4.2 \mathrm{E}-04$ \\
\hline & & & & Am-243 & $1.3 \mathrm{E}-07$ & $2.8 \mathrm{E}-07$ & $2.1 \mathrm{E}-07$ \\
\hline & $\mathrm{Ci} / \mathrm{kg}$ & $\mathrm{Ci} / \mathrm{kg}$ & $\mathrm{Ci} / \mathrm{kg}$ & $\mathrm{Cm}-242$ & $4.3 \mathrm{E}-10$ & $9.0 \mathrm{E}-10$ & $6.7 \mathrm{E}-10$ \\
\hline $\mathrm{C}-14$ & $9.6 \mathrm{E}-10$ & $2.0 \mathrm{E}-09$ & $1.5 \mathrm{E}-09$ & $\mathrm{Cm}-243$ & $2.2 \mathrm{E}-07$ & 4.6E-07 & $3.4 \mathrm{E}-07$ \\
\hline $\mathrm{Ni}-59$ & $3.0 \mathrm{E}-05$ & $6.3 \mathrm{E}-05$ & 4.6E-05 & $\mathrm{Cm}-244$ & $1.4 \mathrm{E}-05$ & $2.9 \mathrm{E}-05$ & $2.1 \mathrm{E}-05$ \\
\hline Ni-63 & $2.5 \mathrm{E}-04$ & $5.2 \mathrm{E}-04$ & $3.8 \mathrm{E}-04$ & $\mathrm{Cm}-245$ & $2.4 \mathrm{E}-09$ & 4.9E-09 & $3.6 \mathrm{E}-09$ \\
\hline Se-79 & $3.4 \mathrm{E}-06$ & $7.2 \mathrm{E}-06$ & $5.3 \mathrm{E}-06$ & $\mathrm{Cm}-246$ & $1.5 \mathrm{E}-10$ & $3.2 \mathrm{E}-10$ & $2.4 \mathrm{E}-10$ \\
\hline Sr-90 & $8.5 \mathrm{E}-03$ & $6.8 \mathrm{E}-03$ & 7.6E-03 & $\mathrm{Cm}-247$ & $1.7 \mathrm{E}-16$ & $3.6 \mathrm{E}-16$ & $2.6 \mathrm{E}-16$ \\
\hline$Y-90$ & $8.5 \mathrm{E}-03$ & $6.8 \mathrm{E}-03$ & $7.6 \mathrm{E}-03$ & $\mathrm{Cm}-248$ & $1.8 \mathrm{E}-16$ & $3.8 \mathrm{E}-16$ & $2.8 \mathrm{E}-16$ \\
\hline $\mathrm{Nb}-94$ & 8.9E-06 & $1.8 \mathrm{E}-05$ & $1.4 \mathrm{E}-05$ & Cf-249 & $1.4 \mathrm{E}-16$ & $2.9 \mathrm{E}-16$ & $2.1 \mathrm{E}-16$ \\
\hline Tc-99 & $7.5 \mathrm{E}-05$ & $1.6 \mathrm{E}-04$ & $1.2 \mathrm{E}-04$ & Cf-250 & $1.1 \mathrm{E}-16$ & $2.3 \mathrm{E}-16$ & $1.7 \mathrm{E}-16$ \\
\hline Ru-106 & $7.4 \mathrm{E}-06$ & $1.5 \mathrm{E}-05$ & $1.1 \mathrm{E}-05$ & Cf-251 & $2.2 \mathrm{E}-18$ & $4.5 \mathrm{E}-18$ & $3.3 \mathrm{E}-18$ \\
\hline
\end{tabular}


Table 28. Adjustment factors to remove contribution of dissolved solids from solids composition of WM-182 and WM-183.

\begin{tabular}{lc}
\hline & Adjustment Factor \\
\cline { 2 - 2 } H-3 & 0 \\
Co-60 & 0 \\
Sr-90 & 0.04 \\
Y-90 & 0.04 \\
Tc-99 & 0.99 \\
Sb-125 & 0.98 \\
Cs-134 & 0.76 \\
Cs-135 & 0.84 \\
Cs-137 & 0.84 \\
Eu-152 & 0.59 \\
Eu-154 & 0.59 \\
Eu-155 & 0.59 \\
U-235 & 0.87 \\
U-238 & 0.58 \\
Other U isotopes & 0.87 \\
Pu-238 & 0.76 \\
Pu-239 & 0.83 \\
Other Pu isotopes & 0.83 \\
Others & 1 \\
\hline
\end{tabular}

Table 29. Estimated WM-188 solids radionuclide concentrations decayed to Jan 2003.

\begin{tabular}{|c|c|c|c|c|c|}
\hline & $\mathrm{Ci} / \mathrm{kg}$ & & $\mathrm{Ci} / \mathrm{kg}$ & & $\mathrm{Ci} / \mathrm{kg}$ \\
\hline C-14 & 5.4E-09 & Pr-144 & $2.8 \mathrm{E}-05$ & $\mathrm{Pu}-240$ & $3.9 \mathrm{E}-04$ \\
\hline $\mathrm{Ni}-59$ & $1.7 \mathrm{E}-04$ & Pm-147 & $7.5 \mathrm{E}-03$ & $\mathrm{Pu}-241$ & $4.2 \mathrm{E}-03$ \\
\hline $\mathrm{Ni}-63$ & $1.4 \mathrm{E}-03$ & Sm-151 & $1.5 \mathrm{E}-02$ & $\mathrm{Pu}-242$ & 2.9E-07 \\
\hline Se-79 & $1.9 \mathrm{E}-05$ & $\mathrm{Eu}-152$ & $6.5 \mathrm{E}-05$ & $\mathrm{Pu}-244$ & $2.5 \mathrm{E}-14$ \\
\hline Sr-90 & 2.0E-01 & Eu-154 & $2.4 \mathrm{E}-04$ & Am-241 & $1.4 \mathrm{E}-03$ \\
\hline Y-90 & $2.0 \mathrm{E}-01$ & Eu-155 & $4.2 \mathrm{E}-03$ & Am-243 & 7.5E-07 \\
\hline $\mathrm{Nb}-94$ & $3.7 \mathrm{E}-03$ & Th-230 & $3.5 \mathrm{E}-08$ & $\mathrm{Cm}-242$ & 2.4E-09 \\
\hline Tc-99 & 4.2E-04 & U-232 & 7.2E-08 & $\mathrm{Cm}-243$ & $1.2 \mathrm{E}-06$ \\
\hline Ru-106 & $4.2 \mathrm{E}-05$ & U-233 & $1.2 \mathrm{E}-09$ & $\mathrm{Cm}-244$ & $7.8 \mathrm{E}-05$ \\
\hline Rh-106 & $4.2 \mathrm{E}-05$ & U-234 & $3.1 \mathrm{E}-05$ & $\mathrm{Cm}-245$ & $1.3 \mathrm{E}-08$ \\
\hline Sn-126 & $1.8 \mathrm{E}-05$ & U-235 & $1.7 \mathrm{E}-07$ & $\mathrm{Cm}-246$ & $8.6 \mathrm{E}-10$ \\
\hline Sb-125 & 4.3E-03 & U-236 & $1.3 \mathrm{E}-06$ & $\mathrm{Cm}-247$ & $9.7 \mathrm{E}-16$ \\
\hline I-129 & $2.4 \mathrm{E}-06$ & U-237 & $2.5 \mathrm{E}-64$ & $\mathrm{Cm}-248$ & $1.0 \mathrm{E}-15$ \\
\hline Cs-134 & $1.7 \mathrm{E}-03$ & U-238 & $6.8 \mathrm{E}-08$ & Cf-249 & $7.8 \mathrm{E}-16$ \\
\hline Cs-135 & $3.3 \mathrm{E}-05$ & $\mathrm{~Np}-237$ & $2.8 \mathrm{E}-06$ & Cf-250 & $6.2 \mathrm{E}-16$ \\
\hline Cs-137 & $1.9 \mathrm{E}+00$ & $\mathrm{Pu}-236$ & $1.0 \mathrm{E}-07$ & Cf-251 & $1.2 \mathrm{E}-17$ \\
\hline Ba-137m & $1.8 \mathrm{E}+00$ & $\mathrm{Pu}-238$ & $5.6 \mathrm{E}-03$ & & \\
\hline Ce-144 & $2.8 \mathrm{E}-05$ & $\mathrm{Pu}-239$ & $3.6 \mathrm{E}-04$ & & \\
\hline
\end{tabular}


Tables 30 and 31 show the composition of solids in Tank WM-180, based on analyses of samples taken of waste transferred to the NWCF feed tanks. The solids were separated from the liquid in the sample by settling and centrifuging, but were not washed. J. Christian, who reported WM-180 sample results $^{3}$, states that approximately $4 \%$ of the weight of the dried solids was due to dissolved solids in interstitial liquid that crystallized during drying. Concentrations shown in Tables 30 and 31 have not been corrected for these crystallized solids.

The value for oxygen shown in Table 30 was calculated by charge balance. The water value was calculated by subtracting the sum of all other species from unity, and agrees well with the measured amount of mass lost during drying of the solids. The elemental composition shown in Table 30 was taken from Table 4 of Reference 3. Table 31 was also taken from Reference 3 and shows the values corrected for interstitial liquid radionuclides.

Table 30. Estimated average composition of undissolved solids from WM-180.

\begin{tabular}{|c|c|c|c|}
\hline Element & $\begin{array}{c}\text { As Elements } \\
(\text { dry basis, wt } \%)\end{array}$ & $\begin{array}{c}\text { As Elements } \\
\text { (with hydrated water, wt \%) }\end{array}$ & $\begin{array}{c}\text { As Elements } \\
\text { (with hydrated water, mol\%) }\end{array}$ \\
\hline $\mathrm{Al}$ & 5.846 & $4.81 \mathrm{E}+00$ & $6.02 \mathrm{E}+00$ \\
\hline $\mathrm{Sb}$ & 0.004 & $3.29 \mathrm{E}-03$ & $9.13 \mathrm{E}-04$ \\
\hline As & $<0.000711$ & $<5.85 \mathrm{E}-04$ & $<2.64 \mathrm{E}-04$ \\
\hline $\mathrm{Ba}$ & 0.0034 & $2.80 \mathrm{E}-03$ & $6.88 \mathrm{E}-04$ \\
\hline $\mathrm{Be}$ & $<0.00019$ & $<1.56 \mathrm{E}-04$ & $<5.86 \mathrm{E}-04$ \\
\hline B & $<0.0511$ & $<4.21 \mathrm{E}-02$ & $<1.31 \mathrm{E}-01$ \\
\hline $\mathrm{Cd}$ & 0.0177 & $1.46 \mathrm{E}-02$ & 4.38E-03 \\
\hline $\mathrm{Ca}$ & 0.4303 & $3.54 \mathrm{E}-01$ & 2.99E-01 \\
\hline $\mathrm{Cl}$ & 0.0909 & $7.48 \mathrm{E}-02$ & 7.13E-02 \\
\hline $\mathrm{Ce}$ & 0.0043 & $3.54 \mathrm{E}-03$ & 8.53E-04 \\
\hline Cs & 0.0524 & 4.31E-02 & $1.10 \mathrm{E}-02$ \\
\hline $\mathrm{Cr}$ & 0.0681 & 5.61E-02 & 3.64E-02 \\
\hline Co & $<0.0015$ & $<1.23 \mathrm{E}-03$ & $<7.08 \mathrm{E}-04$ \\
\hline $\mathrm{Cu}$ & 0.0136 & $1.12 \mathrm{E}-02$ & $5.95 \mathrm{E}-03$ \\
\hline $\mathrm{F}$ & 0.0033 & $2.72 \mathrm{E}-03$ & 4.83E-03 \\
\hline $\mathrm{Gd}$ & 0.0081 & $6.67 \mathrm{E}-03$ & $1.43 \mathrm{E}-03$ \\
\hline $\mathrm{Fe}$ & 2.012 & $1.66 \mathrm{E}+00$ & $1.00 \mathrm{E}+00$ \\
\hline $\mathrm{Pb}$ & 0.0524 & 4.31E-02 & 7.03E-03 \\
\hline $\mathrm{Li}$ & $<0.016$ & $<1.32 \mathrm{E}-02$ & $<6.41 \mathrm{E}-02$ \\
\hline $\mathrm{Mg}$ & 0.1383 & $1.14 \mathrm{E}-01$ & $1.58 \mathrm{E}-01$ \\
\hline $\mathrm{Mn}$ & 0.1568 & $1.29 \mathrm{E}-01$ & 7.94E-02 \\
\hline $\mathrm{Hg}$ & $<0.8904$ & $<7.33 \mathrm{E}-01$ & $<1.23 \mathrm{E}-01$ \\
\hline Mo & 0.0356 & 2.93E-02 & $1.03 \mathrm{E}-02$ \\
\hline $\mathrm{Ni}$ & 0.0276 & $2.27 \mathrm{E}-02$ & $1.31 \mathrm{E}-02$ \\
\hline $\mathrm{Nb}$ & $<1.004$ & $<8.26 \mathrm{E}-01$ & $<3.00 \mathrm{E}-01$ \\
\hline $\mathrm{NO}_{3}$ & 43.43 & $3.58 \mathrm{E}+01$ & $1.95 \mathrm{E}+01$ \\
\hline $\mathrm{Pd}$ & $<0.076$ & $<6.26 \mathrm{E}-02$ & $<1.99 \mathrm{E}-02$ \\
\hline $\mathrm{PO}_{4}$ & 16.659 & $1.37 \mathrm{E}+01$ & $4.88 \mathrm{E}+00$ \\
\hline
\end{tabular}




\begin{tabular}{lllc}
\hline \multicolumn{1}{c}{ Element } & $\begin{array}{c}\text { As Elements } \\
\text { (dry basis, wt } \%)\end{array}$ & $\begin{array}{c}\text { As Elements } \\
\text { (with hydrated water, wt \%) }\end{array}$ & $\begin{array}{c}\text { As Elements } \\
\text { (with hydrated water, mol\%) }\end{array}$ \\
\hline $\mathrm{K}$ & 1.471 & $1.21 \mathrm{E}+00$ & $1.05 \mathrm{E}+00$ \\
$\mathrm{Ru}$ & 0.0359 & $2.96 \mathrm{E}-02$ & $9.88 \mathrm{E}-03$ \\
$\mathrm{Se}$ & $<0.1279$ & $<1.05 \mathrm{E}-01$ & $<4.50 \mathrm{E}-02$ \\
$\mathrm{Si}$ & 2.092 & $1.72 \mathrm{E}+00$ & $2.07 \mathrm{E}+00$ \\
$\mathrm{Ag}$ & 0.0049 & $4.03 \mathrm{E}-03$ & $1.26 \mathrm{E}-03$ \\
$\mathrm{Na}$ & 7.816 & $6.43 \mathrm{E}+00$ & $9.45 \mathrm{E}+00$ \\
$\mathrm{Sr}$ & 0.0022 & $1.81 \mathrm{E}-03$ & $6.98 \mathrm{E}-04$ \\
$\mathrm{SO} 4$ & 1.514 & $1.25 \mathrm{E}+00$ & $4.38 \mathrm{E}-01$ \\
$\mathrm{Tl}$ & $<0.1359$ & $<1.12 \mathrm{E}-01$ & $<1.85 \mathrm{E}-02$ \\
$\mathrm{Sn}$ & $1.75 \mathrm{E}-01$ & $4.97 \mathrm{E}-02$ \\
$\mathrm{Ti}$ & 0.212 & $7.89 \mathrm{E}-02$ & $5.57 \mathrm{E}-02$ \\
$\mathrm{U}$ & 0.0959 & $2.86 \mathrm{E}-02$ & $4.06 \mathrm{E}-03$ \\
$\mathrm{~V}$ & 0.0348 & $<8.23 \mathrm{E}-04$ & $<5.46 \mathrm{E}-04$ \\
$\mathrm{Zn}$ & $<0.001$ & $1.61 \mathrm{E}-02$ & $8.33 \mathrm{E}-03$ \\
$\mathrm{Zr}$ & 0.0196 & $2.30 \mathrm{E}+00$ & $8.52 \mathrm{E}-01$ \\
$\mathrm{Total}$ & 2.797 & 72.0 & 46.78 \\
Oxygen & 87.454 & $3.0($ est) & $6.35 \mathrm{E}+00$ \\
Water & $($ balance) & 25.0 & $4.69 \mathrm{E}+01$ \\
Total & $($ dry basis $)$ & 100.0 & 100.0 \\
\hline & & &
\end{tabular}

Table 31. WM-180 undissolved solids radionuclide concentrations.

\begin{tabular}{ll}
\hline Radionuclide & Ci/kg Solids \\
\hline Am-241 & $3.13 \mathrm{E}-04$ \\
Co-60 & $3.55 \mathrm{E}-05$ \\
Cs-134 & $2.59 \mathrm{E}-04$ \\
Cs-137 & $2.61 \mathrm{E}-01$ \\
Eu-154 & $4.30 \mathrm{E}-04$ \\
$\mathrm{I}-129$ & 0 \\
$\mathrm{~Np}-237$ & $3.37 \mathrm{E}-06$ \\
$\mathrm{Pu}-238$ & $8.75 \mathrm{E}-02$ \\
$\mathrm{Pu}-239$ & $1.30 \mathrm{E}-02$ \\
$\mathrm{Sb}-125$ & $3.37 \mathrm{E}-03$ \\
Total Sr & $6.16 \mathrm{E}-02$ \\
Tc-99 & $2.35 \mathrm{E}-05$ \\
$\mathrm{U}-234$ & $4.31 \mathrm{E}-06$ \\
$\mathrm{U}-235$ & $8.88 \mathrm{E}-08$ \\
$\mathrm{U}-236$ & $1.67 \mathrm{E}-07$ \\
$\mathrm{U}-238$ & $3.79 \mathrm{E}-08$ \\
\hline
\end{tabular}


A sample from the bottom of Tank WM-189 was allowed to settle, and a portion of the settled solids dried and analyzed in 2002. Batchellor reports ${ }^{4}$ that $22 \mathrm{wt} \%$ of the total solids in this dried sample were due to undissolved solids in the sludge, while the remaining portion was from dissolved solids in interstitial liquid. Table 32 shows the composition of the total sludge solids (undissolved and dissolved) as reported by Batcheller.

Table 32. Composition of WM-189 sludge (combined dissolved and undissolved solids). ${ }^{4}$

\begin{tabular}{lrlllr}
\hline & $\mathrm{mg} / \mathrm{kg}$ & & $\mathrm{mg} / \mathrm{kg}$ & & $\mathrm{mCi} / \mathrm{g}$ \\
$\mathrm{Al}$ & $4.74 \mathrm{E}+04$ & $\mathrm{~K}$ & $2.79 \mathrm{E}+04$ & $\mathrm{H}-3$ & $5.50 \mathrm{E}-06$ \\
$\mathrm{Sb}$ & $<4.35 \mathrm{E}+01$ & $\mathrm{Ru}$ & $1.32 \mathrm{E}+02$ & $\mathrm{C}-14$ & $<1.03 \mathrm{E}-06$ \\
$\mathrm{As}$ & $<3.67 \mathrm{E}+01$ & $\mathrm{Se}$ & $<2.59 \mathrm{E}+01$ & $\mathrm{Co}-60$ & $1.51 \mathrm{E}-04$ \\
$\mathrm{Ba}$ & $2.13 \mathrm{E}+01$ & $\mathrm{Si}$ & $4.63 \mathrm{E}+03$ & $\mathrm{Ni}-59$ & $<4.72 \mathrm{E}-03$ \\
$\mathrm{Be}$ & $9.66 \mathrm{E}-01$ & $\mathrm{Ag}$ & $4.64 \mathrm{E}+01$ & $\mathrm{Ni}-63$ & $<7.00 \mathrm{E}-04$ \\
$\mathrm{~B}$ & $6.65 \mathrm{E}+02$ & $\mathrm{Na}$ & $1.67 \mathrm{E}+05$ & $\mathrm{Sr}$ & $1.08 \mathrm{E}-01$ \\
$\mathrm{Cd}$ & $1.06 \mathrm{E}+03$ & $\mathrm{Sr}$ & $4.00 \mathrm{E}+01$ & $\mathrm{Zr}-95$ & $<4.01 \mathrm{E}-05$ \\
$\mathrm{Ca}$ & $7.23 \mathrm{E}+03$ & $\mathrm{~S}$ & $8.37 \mathrm{E}+03$ & $\mathrm{Nb}-94$ & $8.05 \mathrm{E}-05$ \\
$\mathrm{Ce}$ & $<6.45 \mathrm{E}+01$ & $\mathrm{Te}$ & $<5.27 \mathrm{E}+01$ & $\mathrm{Tc}-99$ & $2.81 \mathrm{E}-03$ \\
$\mathrm{Cr}$ & $8.29 \mathrm{E}+02$ & $\mathrm{Tl}$ & $<4.48 \mathrm{E}+01$ & $\mathrm{Sb}-125$ & $<3.00 \mathrm{E}-04$ \\
$\mathrm{Co}$ & $8.22 \mathrm{E}+00$ & $\mathrm{Th}$ & $3.64 \mathrm{E}+01$ & $\mathrm{I}-129$ & $1.15 \mathrm{E}-04$ \\
$\mathrm{Cu}$ & $1.72 \mathrm{E}+02$ & $\mathrm{Sn}$ & $1.39 \mathrm{E}+02$ & $\mathrm{Cs}-134$ & $1.41 \mathrm{E}-01$ \\
$\mathrm{Gd}$ & $7.76 \mathrm{E}+01$ & $\mathrm{Ti}$ & $6.59 \mathrm{E}+01$ & $\mathrm{Cs}-137$ & $5.02 \mathrm{E}-04$ \\
$\mathrm{Au}$ & $<1.17 \mathrm{E}+01$ & $\mathrm{U}$ & $4.06 \mathrm{E}+02$ & $\mathrm{Eu}-154$ & $3.91 \mathrm{E}-06$ \\
$\mathrm{Hf}$ & $<3.02 \mathrm{E}+01$ & $\mathrm{~V}$ & $<1.45 \mathrm{E}+01$ & $\mathrm{U}-234$ & $1.40 \mathrm{E}-07$ \\
$\mathrm{Fe}$ & $4.79 \mathrm{E}+03$ & $\mathrm{Zn}$ & $2.19 \mathrm{E}+02$ & $\mathrm{U}-235$ & $2.92 \mathrm{E}-07$ \\
$\mathrm{~Pb}$ & $5.87 \mathrm{E}+02$ & $\mathrm{Zr}$ & $1.12 \mathrm{E}+04$ & $\mathrm{U}-236$ & $8.13 \mathrm{E}-08$ \\
$\mathrm{Li}$ & $1.39 \mathrm{E}+01$ & $\mathrm{Cl}$ & $<5.10 \mathrm{E}+01$ & $\mathrm{U}-238$ & $1.53 \mathrm{E}-06$ \\
$\mathrm{Mg}$ & $1.15 \mathrm{E}+03$ & $\mathrm{~F}$ & $2.12 \mathrm{E}+03$ & $\mathrm{~Np}-237$ & $2.24 \mathrm{E}-03$ \\
$\mathrm{Mn}$ & $2.61 \mathrm{E}+03$ & $\mathrm{NO} 3$ & $4.24 \mathrm{E}+05$ & $\mathrm{Pu}-238$ & $2.53 \mathrm{E}-04$ \\
$\mathrm{Mo}$ & $1.01 \mathrm{E}+02$ & $\mathrm{PO} 4$ & $1.25 \mathrm{E}+04$ & $\mathrm{Pu}-239$ & $1.33 \mathrm{E}-04$ \\
$\mathrm{Ni}$ & $4.39 \mathrm{E}+02$ & $\mathrm{SO} 4$ & $1.77 \mathrm{E}+04$ & $\mathrm{Pu}-241$ & $2.51 \mathrm{E}-06$ \\
$\mathrm{Nb}$ & $3.35 \mathrm{E}+02$ & & $\mathrm{~mol} / \mathrm{liter}$ & $\mathrm{Cm}-242$ & \\
$\mathrm{Pd}$ & $<4.04 \mathrm{E}+01$ & & $2.80 \mathrm{E}+00$ & $\mathrm{Cm}-244$ & \\
$\mathrm{P}$ & $7.29 \mathrm{E}+03$ & $\mathrm{H}+$ & & & \\
\hline
\end{tabular}

Table 33 presents estimates of the composition of undissolved solids in Tank WM-189 sludge. Because the WM-189 dried solids sample contained a relatively small fraction of undissolved solids ( $\sim 22 \%$, a value which itself contains uncertainty), the values shown in Table 33 contain large uncertainties. The composition shown in Table 33 was calculated by subtracting the contribution of dissolved species from the composition of the dried solids. In doing the calculations, the fraction of dissolved species was adjusted from $78 \%$ to $63 \%$ to avoid a negative concentration of nitrate in the undissolved solids (as well as negative contributions of other species). The amount of oxygen was calculated by charge balance. 
Table 33. Estimated composition of WM-189 undissolved solids.

\begin{tabular}{lrlc}
\hline & $\mathrm{mol} \%$ & & $\mathrm{mCi} / \mathrm{g}$ \\
\hline $\mathrm{Al}$ & $3.2 \%$ & $\mathrm{Co}-60$ & $1.31 \mathrm{E}-04$ \\
$\mathrm{~K}$ & $3.2 \%$ & $\mathrm{Sr}-90$ & $1.60 \mathrm{E}-02$ \\
$\mathrm{Si}$ & $2.7 \%$ & $\mathrm{Nb}-94$ & $6.07 \mathrm{E}-05$ \\
$\mathrm{Na}$ & $47.1 \%$ & $\mathrm{Tc}-99$ & $2.21 \mathrm{E}-03$ \\
$\mathrm{Zr}$ & $2.0 \%$ & $\mathrm{Cs}-134$ & $2.77 \mathrm{E}-05$ \\
$\mathrm{~F}$ & $1.2 \%$ & $\mathrm{Cs}-137$ & $3.30 \mathrm{E}-02$ \\
$\mathrm{PO} 4$ & $2.1 \%$ & $\mathrm{Eu}-154$ & $1.23 \mathrm{E}-04$ \\
$\mathrm{SO} 4$ & $0.7 \%$ & $\mathrm{U}-234$ & $5.47 \mathrm{E}-07$ \\
$\mathrm{O}$ & $36.6 \%$ & $\mathrm{U}-235$ & $4.98 \mathrm{E}-09$ \\
others & $1.3 \%$ & $\mathrm{U}-236$ & $8.02 \mathrm{E}-08$ \\
& & $\mathrm{U}-238$ & $2.69 \mathrm{E}-09$ \\
& & $\mathrm{~Np}-237$ & $4.90 \mathrm{E}-07$ \\
& & $\mathrm{Pu}-238$ & $1.23 \mathrm{E}-03$ \\
& & $\mathrm{Pu}-239$ & $1.39 \mathrm{E}-04$ \\
& & $\mathrm{Pu}-241$ & $7.35 \mathrm{E}-02$ \\
& & $\mathrm{Am}-241$ & $8.40 \mathrm{E}-06$ \\
& & $\mathrm{Cm}-242$ & $3.02 \mathrm{E}-08$ \\
\hline
\end{tabular}

Swenson ${ }^{9}$ collected and published results of analyses of tanks solids performed in the early 1980's. Although the solids in the tanks now and in the future may differ from these historical samples, Swenson's data provide additional estimates of the potential range of composition of solids in the different tanks. Arlin Olson used the data contained in Swenson's report, Historical Tank Farm Sample Results $^{9}$ to estimate an average composition of solids, shown in Table 34. Historical data from specific tanks are shown in Table 35.

Table 34. Estimated average composition of undissolved solids.

\begin{tabular}{|c|c|c|}
\hline & $\mathrm{Wt} \%$ & Likely Forms \\
\hline $\mathrm{Al}$ & 2.01 & $\mathrm{AlPO}_{4}$ \\
\hline B & 3.34 & $\mathrm{~B}_{2} \mathrm{O}_{3}$ \\
\hline $\mathrm{Ca}$ & 1.02 & $\mathrm{CaF}_{2}$ \\
\hline $\mathrm{Cr}$ & 0.26 & $\mathrm{Cr}_{2} \mathrm{O}_{3}$ \\
\hline $\mathrm{Fe}$ & 2.79 & $\mathrm{FePO}_{4}-2 \mathrm{H}_{2} \mathrm{O}$ \\
\hline $\mathrm{Hg}$ & 0.66 & $\mathrm{HgCl}_{2}$ \\
\hline K & 1.79 & $\mathrm{KNbO}_{3}, \mathrm{KCl}$ \\
\hline $\mathrm{Mn}$ & 0.44 & $\mathrm{MnO}_{2}$ \\
\hline $\mathrm{Na}$ & 4.88 & $\mathrm{NaCl}, \mathrm{Na}_{3} \mathrm{PO}_{4}$ \\
\hline $\mathrm{Nb}$ & 0.17 & $\mathrm{KNbO}_{3}$ \\
\hline $\mathrm{Ni}$ & 1.64 & $\mathrm{NiO}$ \\
\hline $\mathrm{Si}$ & 4.58 & $\mathrm{SiO}_{2}$ \\
\hline $\mathrm{Zr}$ & 15.62 & $\mathrm{ZrO}_{2}, \mathrm{Zr}\left(\mathrm{SO}_{4}\right)_{2}-4 \mathrm{H}_{2} \mathrm{O}$ \\
\hline $\mathrm{Cl}$ & 3.05 & $\mathrm{NaCl}, \mathrm{KCl}, \mathrm{HgCl}_{2}$ \\
\hline $\mathrm{F}$ & 2.98 & $\mathrm{CaF}_{2}, \mathrm{NaF}$ \\
\hline $\mathrm{PO}_{4}$ & 14.07 & $\mathrm{AlPO}_{4}, \mathrm{Na}_{3} \mathrm{PO}_{4}, \mathrm{FePO}_{4}-2 \mathrm{H}_{2} \mathrm{O}$ \\
\hline $\mathrm{SO}_{4}$ & 16.45 & $\mathrm{Zr}\left(\mathrm{SO}_{4}\right)_{2}-4 \mathrm{H}_{2} \mathrm{O}$ \\
\hline $\mathrm{H}_{2} \mathrm{O}$ & 7.97 & as per above hydrates \\
\hline \multirow[t]{2}{*}{$\mathrm{O}$} & 16.29 & as per above oxides \\
\hline & 100.00 & \\
\hline
\end{tabular}


Table 35. Variation in solids composition based on 1983 samples.

\begin{tabular}{|c|c|c|c|c|c|c|c|}
\hline & & $\begin{array}{c}\text { WM-180 } \\
\mathrm{mg} / \mathrm{g}\end{array}$ & $\begin{array}{c}\text { WM-181 } \\
\mathrm{mg} / \mathrm{g}\end{array}$ & $\begin{array}{c}\text { WM-184 } \\
\mathrm{mg} / \mathrm{g}\end{array}$ & $\begin{array}{c}\text { WM-186 } \\
\mathrm{mg} / \mathrm{g}\end{array}$ & & $\begin{array}{c}\text { WM-185 } \\
\mathrm{mg} / \mathrm{g}\end{array}$ \\
\hline $\mathrm{Al}$ & & 13.85 & 7.65 & 36 & 0.645 & $\mathrm{Al}$ & 0.2 \\
\hline B & & 8.1 & $<12$ & 53.1 & $<0.74$ & B & \\
\hline $\mathrm{Ca}$ & & 6.9 & 10.75 & 10.2 & 0.845 & $\mathrm{Ca}$ & 0.35 \\
\hline $\mathrm{Cr}$ & & 0.81 & 5.05 & 0.76 & 0.52 & $\mathrm{Cr}$ & 1 \\
\hline $\mathrm{Fe}$ & & 14.4 & 18.6 & 10.9 & 2.265 & $\mathrm{Fe}$ & 40 \\
\hline $\mathrm{Hg}$ & & 0.52 & $<0.12$ & 13.38 & $<0.007$ & $\mathrm{Hg}$ & 1.2 \\
\hline $\mathrm{Na}$ & & 34.9 & 24 & 74.75 & 1.48 & $\mathrm{Na}$ & 6.7 \\
\hline $\mathrm{Ni}$ & & 6.2 & 30.6 & 6.65 & 1.49 & $\mathrm{Ni}$ & \\
\hline PO4 & & 130 & 106 & 60 & 8.2 & PO4 & 110 \\
\hline K & & 3.95 & 48.1 & 3.1 & 2.97 & K & 0.2 \\
\hline $\mathrm{U}$ & & & & 1.09 & & $\mathrm{U}$ & \\
\hline \multirow[t]{3}{*}{$\mathrm{Zr}$} & & 94 & 53.5 & 40.8 & 4.3 & $\mathrm{Zr}$ & $>300$ \\
\hline & & $\mathrm{mCi} / \mathrm{g}$ & $\mathrm{mCi} / \mathrm{g}$ & $\mathrm{mCi} / \mathrm{g}$ & $\mathrm{mCi} / \mathrm{g}$ & & $\mathrm{mg} / \mathrm{g}$ \\
\hline & & $8 / 25 / 83$ & $7 / 8 / 83$ & $8 / 3 / 83$ & $7 / 14 / 83$ & $\mathrm{Mg}$ & 0.5 \\
\hline Co- 60 & & & & $4.68 \mathrm{E}-04$ & $2.70 \mathrm{E}-05$ & $\mathrm{Mn}$ & 0.4 \\
\hline Sr-90 & & $3.96 \mathrm{E}-01$ & 4.47E-02 & 8.19E-02 & $3.76 \mathrm{E}-03$ & Mo & 0.07 \\
\hline Nb-95 & & & $2.10 \mathrm{E}-01$ & $3.05 \mathrm{E}-01$ & $1.73 \mathrm{E}-02$ & $\mathrm{Nb}$ & 0.2 \\
\hline Zr-95 & & & $7.00 \mathrm{E}-02$ & $1.34 \mathrm{E}-01$ & $6.49 \mathrm{E}-03$ & $\mathrm{~Pb}$ & 0.3 \\
\hline Ru-106 & & & $1.99 \mathrm{E}-01$ & $3.62 \mathrm{E}-01$ & $3.43 \mathrm{E}-02$ & $\mathrm{Si}$ & 9.25 \\
\hline $\mathrm{Sb}-125$ & & & $1.42 \mathrm{E}-01$ & $3.24 \mathrm{E}-01$ & $1.32 \mathrm{E}-02$ & $\mathrm{Sn}$ & 15 \\
\hline Cs-134 & & & & $5.81 \mathrm{E}-03$ & $1.28 \mathrm{E}-04$ & $\mathrm{Ti}$ & 0.2 \\
\hline Cs-137 & & & $5.32 \mathrm{E}-02$ & $8.73 \mathrm{E}-01$ & $4.38 \mathrm{E}-03$ & & \\
\hline Ce-144 & & & & $1.51 \mathrm{E}-02$ & $4.05 \mathrm{E}-04$ & & \\
\hline Am-241 & $<$ & $1.12 \mathrm{E}-03$ & $<3.91 \mathrm{E}-03$ & $<7.03 \mathrm{E}-04$ & $<1.68 \mathrm{E}-04$ & & \\
\hline Np-237 & & $8.9 \mathrm{E}-06$ & $<3.5 \mathrm{E}-07$ & $2.6 \mathrm{E}-06$ & $5.4 \mathrm{E}-08$ & & \\
\hline $\mathrm{Pu}-238$ & & 7.3E-02 & $1.5 \mathrm{E}-02$ & 5.1E-02 & $1.2 \mathrm{E}-03$ & & \\
\hline $\mathrm{Pu}-239$ & & $9.4 \mathrm{E}-03$ & 2.7E-03 & 7.2E-03 & $1.9 \mathrm{E}-04$ & & \\
\hline $\mathrm{Pu}-240$ & & $2.2 \mathrm{E}-03$ & $4.5 \mathrm{E}-04$ & $2.6 \mathrm{E}-03$ & $4.8 \mathrm{E}-05$ & & \\
\hline $\mathrm{Pu}-241$ & & $1.5 \mathrm{E}-01$ & 2.7E-02 & $8.2 \mathrm{E}-02$ & $1.8 \mathrm{E}-03$ & & \\
\hline $\mathrm{Pu}-242$ & & $2.1 \mathrm{E}-06$ & 7.6E-07 & $1.4 \mathrm{E}-06$ & $2.0 \mathrm{E}-08$ & & \\
\hline
\end{tabular}


The following tank solids compositions are recommended for use in FY-2003 design studies:

Separate Processing Alternatives

Feeds to liquid processing

1 Solids in WM-180 liquid

2 Solids in WM-188 liquid

3 Solids in WM-189 liquid

Feed to solids processing

4 Solids in WM-187 slurry

$5 \quad$ Slurried filter cake from liquid processing

6 Solids in flushes from WM-180

7 Solids in flushes from WM-188

8 Solids in flushes from WM-189
Suggested Composition

Tables $30 \& 31$

Tables $29 \& 34$

Table 27 (for rad only) and Table 34

Table 27, average

Calculated from \#1-3

Tables $30 \& 31$

Table 27, average

Table 27, average

Coprocessing Alternatives

9 Solids in WM-180 liquid

10 Mixed solids from blended waste from WM-188

11 Mixed solids from blended waste from WM-189

12 Mixed solids from blended waste from WM-187
Tables $30 \& 31$

Table 27, average

Table 27, average

Table 27, average

As results from additional solids analyses become available, they should be incorporated into design studies.

\subsection{Solids properties}

Poloski ${ }^{10}$ reports that the particle density of air-dried solids from the WM-183 LDUA sample was measured at $1.88 \mathrm{~g} / \mathrm{ml}$. Using measurements of the sludge sample mass, volume and percent water for the same tank sample, a solids particle density of $1.98 \mathrm{~g} / \mathrm{ml}$ can be derived.

Particle size distributions (PSD) are reported for WM-180 solids by Christian, ${ }^{3}$ for WM-182 and WM-183 solids by Poloski, ${ }^{7}$ and for WM-189 solids by Batcheller. ${ }^{4}$ The WM-180 solid particles were normally distributed between 0.2 and $65 \mu \mathrm{m}$, with the center of the distribution at $10 \mu \mathrm{m}$. ${ }^{3}$ PSDs for WM182 and WM-183 sonicated solids show median particle sizes of $8 \mu \mathrm{m}$ and $12 \mu \mathrm{m}$ respectively. Without sonification, the WM-182 and WM-183 solids size distributions are shifted to larger particle sizes. ${ }^{7}$ Particle sizes for the WM-189 sludge sample ranged from 0.6 to $100 \mu \mathrm{m}$ with a peak at approximately 20 $\mu \mathrm{m} .{ }^{4}$ A comparison of particle size distribution for solids from WM-180, WM-182 (without sonification), WM-183 (without sonification) and WM-189, as reported by Batcheller, ${ }^{4}$ is shown in Figure 1. 


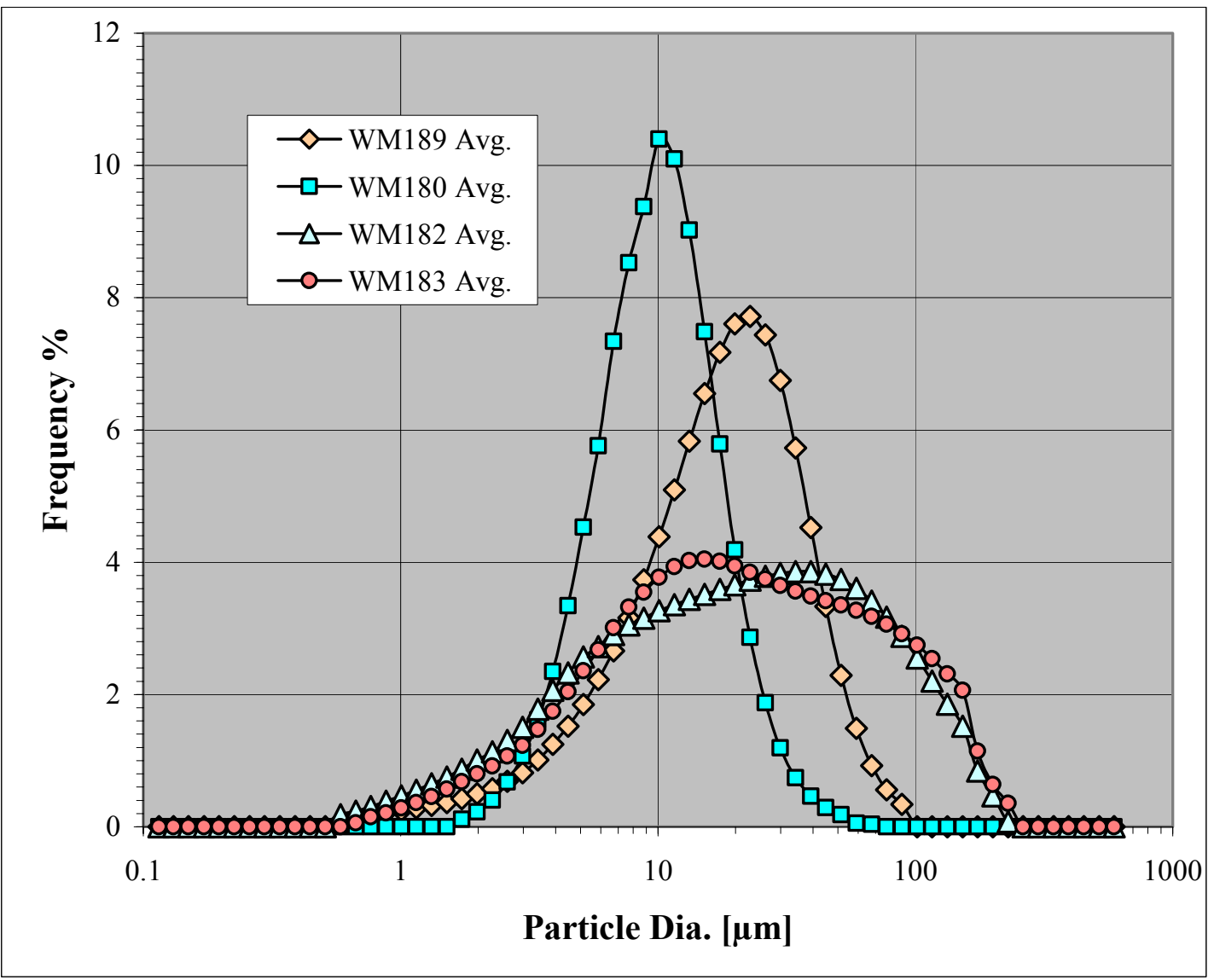

Figure 1. Comparison of WM-189, WM-180, WM-182, and WM-183 solids particle size distribution analyses under non-sonicated condition (from Reference 4).

Poloski ${ }^{7}$ also report settling rate data for solids in the WM-182 LDUA sample. To obtain a settling rate, a sample was shaken, and photographs taken as the solids settled. From the photographs, the height of the solids layer was measured and the following results calculated:

\begin{tabular}{ccc}
\hline Time, $\min$ & Percent settled & Interface velocity, $\mathrm{mm} / \mathrm{hr}$ \\
\hline 20 & 8 & - \\
38 & 12 & 9.2 \\
78 & 21 & 7.4 \\
122 & 28 & 5.4 \\
138 & 30 & 5.2 \\
152 & 31 & 4.9 \\
\hline
\end{tabular}

Batcheller reports results of settling tests for solids from WM-189. ${ }^{4}$ In these tests, a $250 \mathrm{ml}$ bottle of WM-189 sample was agitated and $18 \mathrm{ml}$ were transferred to a graduated cylinder. Settled solids volume was then recorded versus time. Three tests were performed; the results are shown in Figure 2. 


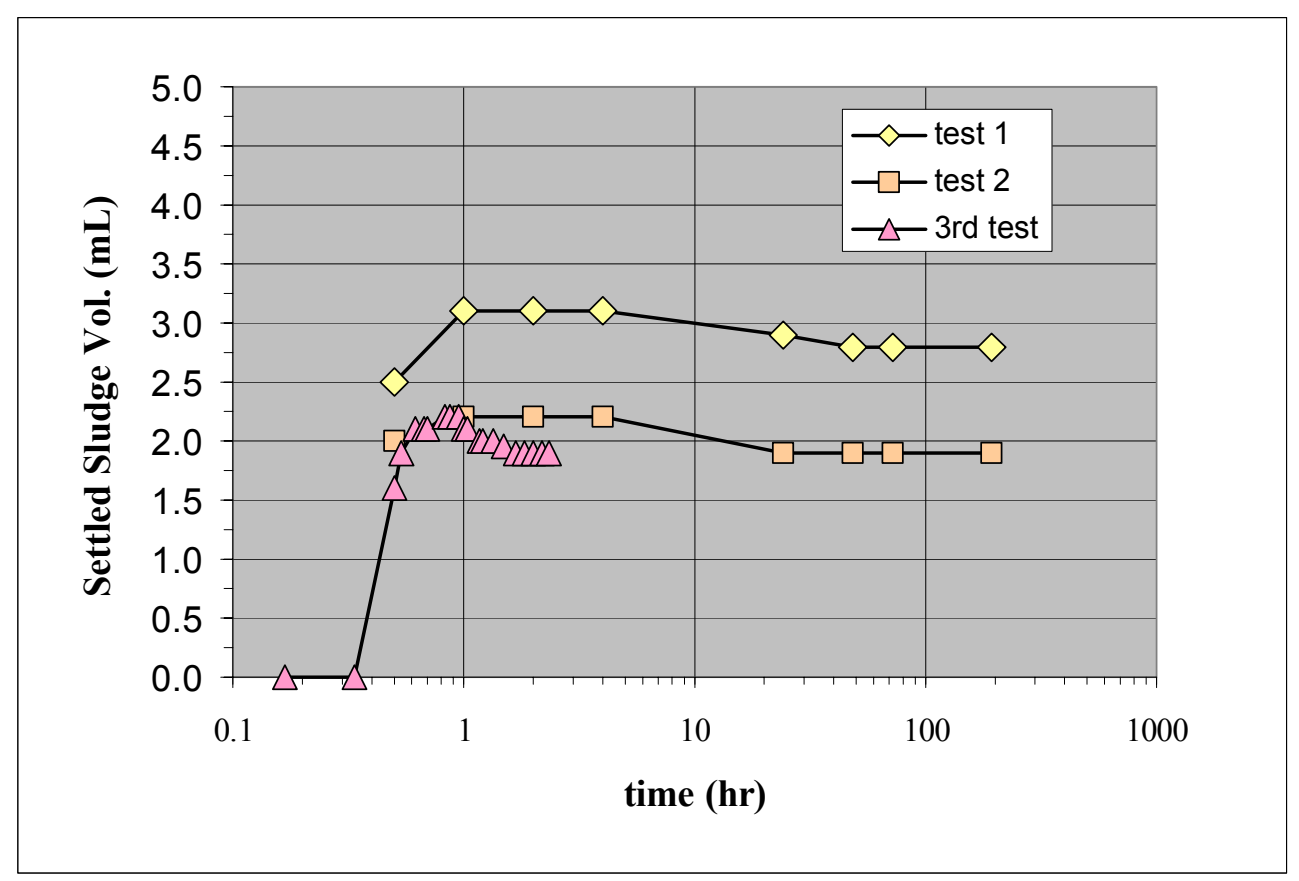

Figure 2. WM-189 solids settling rate.

Batcheller compares settling rates of WM-182 solids with WM-189 solids and discusses possible differences between the two sludge samples that could cause the different settling rates. ${ }^{4}$ A graphical comparison, taken from his report, is shown in Figure 3. Batcheller concluded that the primary factor contributing to the different settling rate of the two samples is the higher "sludge loading" of the WM-182 sample. The sludge in the WM-189 sample amounted to about $16 \%$ of the sample, whereas the sludge in the WM-182 sample was approximately $60 \%$. Batcheller also notes that the WM-182 solids were dark and nearly opaque, while the WM-189 solids were light gray in color and fairly translucent.

Based on the flow curve for WM-182 sludge, Poloski concluded that this sludge exhibited pseudoplastic behavior. ${ }^{24}$ Viscosity measurements were made on both the settled WM-182 sludge and same sludge diluted with an equal volume of demineralized water. Poloski fit the data to the following flow curves:

Undiluted WM-182 sludge:

Shear stress, dyne $/ \mathrm{cm}^{2}=7.25 \times\left(\text { shear rate, } \mathrm{sec}^{-1}\right)^{0.619} \quad \mathrm{R}^{2}=0.997$

Diluted WM-182 sludge:

Shear stress, dyne $/ \mathrm{cm}^{2}=10.25 \times\left(\text { shear rate, } \sec ^{-1}\right)^{0.218} \quad \mathrm{R}^{2}=0.988$

The viscosity of WM-182 undiluted sludge was approximately $200 \mathrm{cP},{ }^{24} \mathrm{WM}-182$ sludge diluted with an equal volume of water about $50 \mathrm{cP},{ }^{24}$ and WM-189 $3.5 \mathrm{cP} .{ }^{4}$ Based on the viscosity measurements of WM-189 "as received" sample and sludge, Batcheller ${ }^{4}$ recommended that sludge viscosity measurements be performed using instrumentation with at least 500 reciprocal seconds shear rate in order to obtain accurate values. The maximum shear rate of the instrument used WM-189 viscosity measurements was $79 \mathrm{sec}^{-1}$. 
Harbour et $\mathrm{a}^{15}$ used the chemical and particle size distribution data from WM-182 and WM-183 LDUA samples to prepare simulants of INEEL tank solids and then measured shear stress versus shear rate for the prepared slurries. One simulant was prepared with water as the liquid, another with 0.4 molar nitric acid. Shear stress versus shear rate curves for these two simulants are shown in Figures 4 and 5.



Figure 3. WM-189 and WM-182 Relative Volume \% Settled Sludge vs. Settling Time.

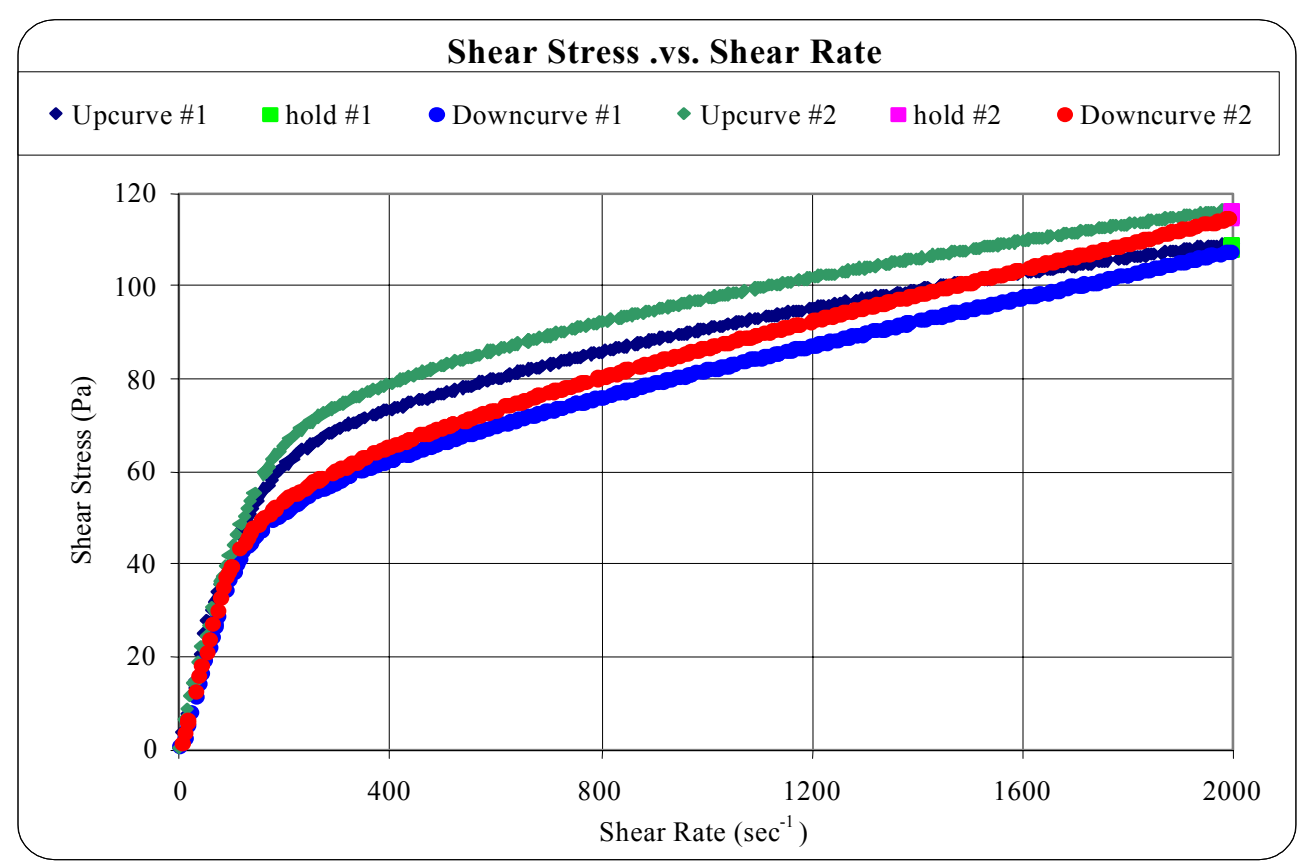

Figure 4. Shear Stress versus Shear Rate; solids in water. 


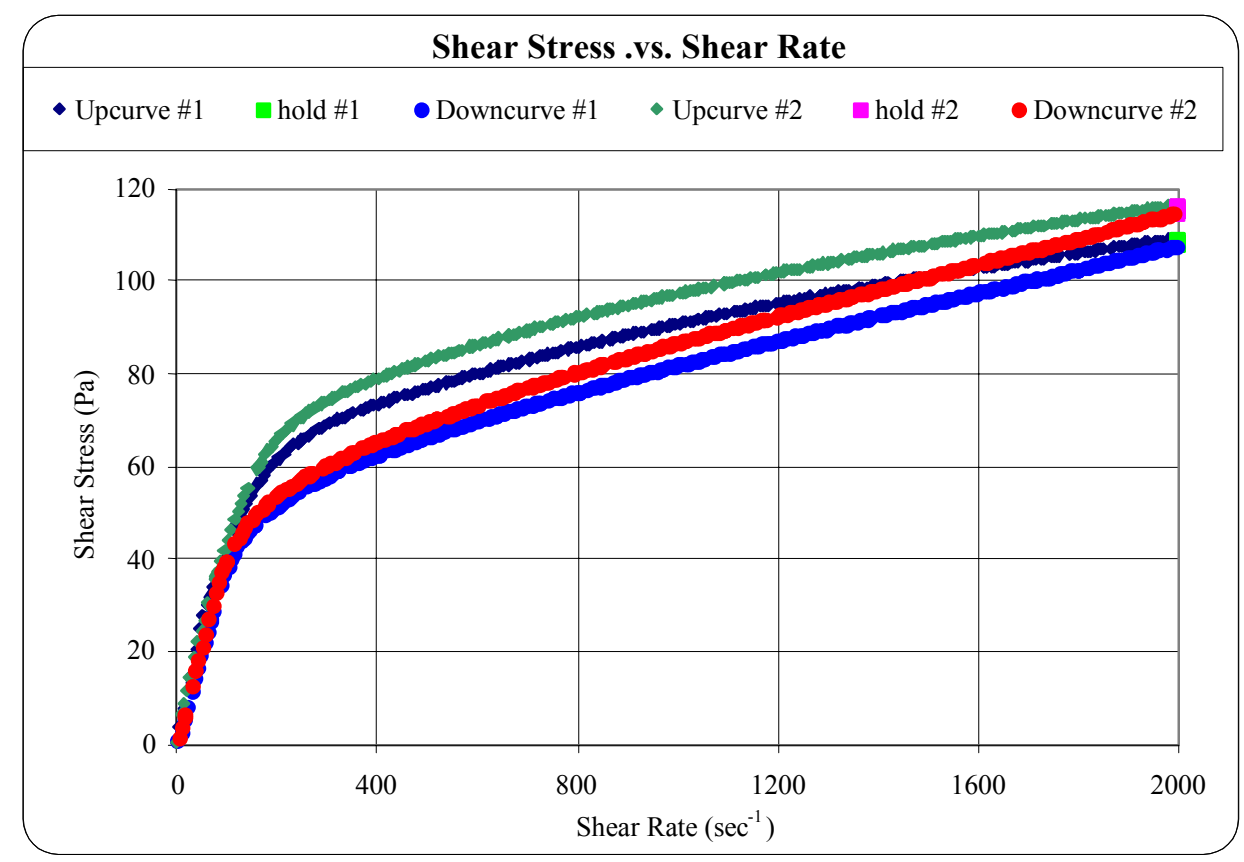

Figure 5. Shear Stress versus Shear Rate; Solids in 0.4 molar nitric acid. 


\section{UNCERTAINTIES AND CHARACTERIZATION RECOMMENDATIONS}

Uncertainties present in compositions and properties given in this report are identified and briefly discussed in this section. Additional waste characterization will reduce many of the uncertainties identified below. The uncertainties are presented in order to plan additional waste sampling and characterization and to provide a basis for defining treatment facility feeds that incorporate uncertainties in composition.

\subsection{Liquid Composition Uncertainties}

Uncertainties present in compositions of liquids in Tanks WM-180 and WM-189 are due primarily to analytical and sampling techniques. Table 1, which compares analysis of Tank WM-180 samples taken in 1993 and 2000, shows that for major components, concentrations of chemical species agree to within 3-13\%. Agreement is good (1-2\%) for some minor species, such as $\mathrm{Ni}$ and $\mathrm{Cr}$, and poor for others, such as calcium (39\% variation) and sulfate (63\% variation). A few trace species can show as much as an order of magnitude difference. Batcheller and Taylor provide uncertainties for WM-189 liquid analyses (Tables 3-3 and 3-4 of Ref. 4). Except for measurements of VOCs and SVOCs, uncertainties for WM-189 chemical species are 10-25\%. The uncertainty in the VOC and SVOC analysis of WM-189 liquid is $85-107 \%{ }^{4}$ Uncertainties for radionuclides vary from $7-100 \%{ }^{4}$

The projected composition for Tank WM-188 contains additional uncertainties because it has been derived from analysis data of multiple wastes, uncertainties in projected waste compositions and volumes, estimates of specie partitioning in evaporators, and estimates of evaporation concentration factors. Analytical results from future samples of WM-188 waste will greatly reduce these uncertainties.

Radiological analyses of the various tank samples have been limited to a relatively small set of major radionuclides, as identified in Tables 2 and 5. Concentrations for other radionuclides are estimates that could contain large uncertainties. Sensitivity studies may be appropriate during treatment facility design to determine whether these estimated concentrations would effect the treatment facility design.

Section 2.7 summarizes concentrations and speciation of organic materials in the liquid SBW. Organic chemicals which are used in decontamination solutions that become generated waste and added to SBW are known, but the degree to which these compounds react with SBW or partition in evaporation steps has not been fully determined. TOC, VOC and SVOC analyses have been performed on a sample of WM-189 waste, but not for samples of WM-180 or WM-188. For certain treatment processes, additional analysis of wastes for organics may be needed to ensure that final waste forms meet disposal criteria.

The average concentration of undissolved solids entrained in liquid waste is uncertain. No data is available to determine how the concentration of undissolved solids will change over time as a tank is emptied or if the solids that get entrained with liquid being removed have different chemical or physical properties from the solids that have settled to the bottom of that tank. For treatment processes that coprocess solids, equipment will be added to the TFF tanks to blend the wastes and produce more homogeneous feeds. For alternatives that process tank liquids and solids separately, the design will need to accommodate this variability in solids concentration and properties.

The estimated compositions and projected volumes of generated waste streams contain uncertainty. It is uncertain whether some waste streams, such as non-INTEC streams, will be processed by INTEC evaporators and ultimately the SBW treatment process. Conversely, actual generation rates for 
other streams may differ from present projected quantities. Updated projections of waste generation rates should be reviewed to determine what effect new rates would have on the treatment facility.

Tables 13 and 14 illustrate the uncertainty present in the composition of generated waste streams. Additional uncertainties are present in estimated blends of these wastes because no analytical data is available for some of the streams. Radionuclide concentrations for generated waste were assumed to be equal to SBW, and thus contain a large uncertainty. While uncertainties in the composition of generated waste streams are large, the generated waste contributes a relatively small fraction to the total waste processed by the treatment facility.

A tank-blending scenario was assumed to calculate compositions of the feeds for treatment alternatives that coprocess solids. Additional sample analyses and evaluations are planned that could result in recommended changes to the tank-blending scenario and hence the blended tank compositions. In addition, updates to the Tank Farm Management Plan ${ }^{14}$ could require changes to the tank-blending scenario. As these changes are made, the effect on the designs for the different treatment alternatives should be reviewed.

\subsection{Uncertainties in Solids Quantity, Composition and Properties}

Section 3.1 presents the basis for both "expected" and "maximum" quantities of solids in the TFF tanks. Various treatment alternative design studies should consider which estimate is most appropriate for that particular study. Additional solids data will be obtained within the next nine months that should significantly reduce the uncertainty in the total solids quantity estimate. Sources of uncertainties in the present estimate are due to:

$\underline{\text { Solids in WM-180 }}$

1. The assumed depth of settled solids in WM-180.

2. The assumed fraction of solids in the settled solids layer.

3. The assumed solids particle density for WM-180 solids.

Solids in WM-188 \& WM-189

4. As discussed in Section 3.1, the quantities of solids in WM-188 and WM-189 are estimates that sought to be consistent with observations of samples from the different tanks, but are not based on any direct measurements.

$\underline{\text { Solids in WM-187 }}$

5. The assumption that all present solids in each tank being flushed to WM-187 are removed by washing.

6. The assumption that no solids form or dissolve during flushing to WM-187 or as additional wastes are added to the tank.

7. The assumed average fraction of solids in the settled solids layer of the different tanks that will be flushed to WM-187.

8. The assumed particle density for the combined solids in WM-187. 
Solids in WM-187, WM-188, and WM-189 after Tank Blending

9. The assumption that no solids form or dissolve during the blending process. The WM-187 solids initially are contained in a dilute acid and salt solution, but are then mixed with a higher acidic and concentrated salt solution and transferred back to other tanks of slightly different chemistry.

10. The assumption that the solids in each tank will be uniformly mixed.

Analyses are available (Tables 30 and 31) for solids from WM-180. However, it is not known whether the solids in this particular sample are representative of solids in the entire tank. In addition, uncertainties are present for these solids analyses because of the very small amount of solids that were in the WM-180 sample. Since Tank WM-180 contains a relatively small quantity of solids, the uncertainty in the composition should have a negligible effect on the design of most treatment processes.

No comparable analyses are available for WM-188 \& WM-189 solids, hence the recommended composition of solids in these tanks are estimates and could contain large uncertainty. Recommended radionuclide concentrations for Tank WM-188 solids are based on analyses of solids prior to filling the tank with the present volume of SBW liquid. As for Tank WM-180, it is not known whether the solids composition will change over time as these two tanks are emptied. The composition of solids in WM-187 is based on the composition of only a portion (estimated to be $\sim 30 \%$ ) of the total solids that will be present in the tank. Analyses of WM-188 solids will be performed in early CY 2003 and provide a better composition for these solids.

Solids density is presently available only for a sample from one tank. Settling rate measurements were made for solids from two tanks and show large differences. Present rheology data for SBW solids (Figures $4 \& 5$ ) are based on measurements of a simulant and a sludge sample from one tank (WM-189).

\subsection{Characterization Needs}

Liquids and solids from the Tank Farm Facility will be the feeds to the SBW Treatment Facility. Additional characterization data is needed to reduce risks in the design of these treatment processes due to the uncertainties discussed above. Characterization data is also needed to develop simulants for testing unit operations of the different alternatives. This test data will form the design basis for the treatment facility and verify that equipment meet performance requirements. Characterization data will also be needed to verify that waste products from the treatment facility meet disposal site waste acceptance criteria and transportation requirements. Many of the characterization needs discussed below have been incorporated into the Tank Sampling and Characterization Plan. ${ }^{28}$

\subsubsection{Tank WM-188 Liquid}

Tank WM-188 was sampled in late 2002, and analyses of these samples will provide better compositional data for this tank than the estimates presently in this report. Tank WM-188 is currently about three-quarters full. Additional samples of the tank should be taken when the tank is full, expected to be in the 2005-2006 timeframe, in order to confirm the composition for this tank waste used in the treatment facility design. Analyses for organics, including VOCs and SVOCs, should be included in the analyses performed on WM-188 samples. 


\subsubsection{Generated Liquid Wastes}

Liquid wastes generated through FY-2005 are considered "sodium-bearing waste" and will be concentrated in existing INTEC evaporators and sent to Tank WM-188. Either composition of wastes added to WM-188 or samples of WM-188 after additions are needed to confirm that the waste from this tank remains within the design feed range.

Waste generated after FY-2005 is referred to as newly generated liquid waste and is currently planned to be stored in Tanks WM-100, WM-101 and WM-102. Evaluations are currently underway to determine whether this waste will be treated in the SBWT Facility, in other on-site facilities or sent offsite for treatment and disposal. Composition data will be needed for these wastes to continue to evaluate treatment options and to verify final waste forms meet disposal requirements.

A Sampling and Analysis Plan (PLN-613) has been issued ${ }^{29}$ for these liquid waste streams that addresses characterization relative to Resource Conservation and Recovery Act (RCRA) Part B permit compliance and hazardous waste treatment, i.e., use of existing evaporators to concentrate the waste, and also characterization to treat, store and dispose of these wastes. As the treatment path of the NGLW becomes more definite, PLN-613 should be reviewed and updated as needed. However two needs apparent at this time are for radioanalysis to determine concentrations of radionuclides in NGLW streams and organic analyses to better determine the amount and speciation of organics in NGLW. Also, cesium should be added to the list of 27 chemical species that PLN-613 identifies for analysis.

\subsubsection{Volume of Solids}

An improved estimate of the total volume of tank solids is needed. The volume of solids will affect the feed rate to the treatment facility and hence sizing of all equipment that processes solids, either separately or together with liquid waste. The volume of solids will also affect the volume of treatment facility wastes and hence waste disposal costs for the SBWT facility.

To obtain a better estimate of the total volume of solids in the TFF, samples should be taken of the waste in Tanks WM-181, WM-184, WM-185, WM-186 and WM-187. All of these tanks except WM-187 are currently at heel level and will over the next few years be washed to WM-187. The flushing process will exchange the high acid and high salt solution of the present interstitial liquid with a very dilute aqueous solution. To obtain better estimates of the solids currently in the tank heels, the solids fraction of the samples as-received is needed. Data is also needed that will provide a basis for determining how much if any the quantity of solids increases or decreases during the (a) the tank flushing process, in which a tank heel is flushed with water, and (b) the tank mixing process, in which the solids in WM-187 are mixed with SBW from other tanks.

\subsubsection{Solids Physical Properties}

Settling Rate Data. Figure 3 shows widely different settling rates for solids from two different tanks. Because the solids that will be received for processing in the treatment facility will not be combined in WM-187 for several years, a greater understanding of the causes of these differences is needed. Data is needed on settling rate of solids in the dilute acid and salt solution that will be present in WM-187. Then an analysis of the variables that affect the settling rate is needed with appropriate tests to determine the relationships between these variables and settling rate. Settling rate data is needed to size the treatment facility solids receiving tank for separate processing alternatives, and also to design equipment and piping to transfer the solids to the receiving tank and then from the tank to solids processing equipment. 
Filtration Rate Data. Filtration rate data is needed for SBW (from Tanks WM-180, WM-188 and WM189) with a low concentration of undissolved solids and for a slurry or high solids concentration in a dilute acid and salt solution (from Tank WM-187). The CsIX alternative is expected to have two separate filters for these two different types of feed. Filtration rate data is needed to help determine the feasibility and performance of filtration for these two applications.

Bulk Dry, Particle and Slurry Density. The bulk dry density is needed to determine the volume of final solids waste. A curve of slurry density versus solids content, from zero to $25 \mathrm{wt} \%$ solids, is needed to design equipment to transport the solids. Dry density is needed for WM-187 solids, i.e., undissolved solids in a very dilute aqueous solution. Slurry density is needed for slurries representative of tanks waste after mixing, i.e., WM-187 solids remixed with SBW from the other tanks, and of WM-187 solids in dilute solution. Also, the particle density is needed to evaluate settling and to better determine tank solids quantities.

Slurry viscosity. The slurry viscosity over the range of zero to $25 \mathrm{wt} \%$ solids is also needed to design equipment to transport the solids.

Particle Size Distribution with and without Sonification. The particle size distribution (PSD) is needed to select the solids filter and design a settling tank for the tank solids slurry. Previous PSD analysis of samples obtained with the Light Duty Utility Arm (LDUA) showed that sonification significantly affected the PSD, indicating that the samples as received contained flocculent particles.

Moisture Content of Filtered and Dried Solids. The assumed disposal form of the tank solids at the present time is as bulk, dry solids. Various methods of drying the solids could be used. To select and design a drying method the moisture content of the solids are needed, as filtered, and also after air-drying. The air-dried moisture content of the solids is also needed to calculate potential hydrogen generation in the waste container. This moisture-content data needs to include all forms of water, whether residual adsorbed water or water of hydration. For these measurements, the sample should be representative of the solids that will be in Tank WM-187.

\subsubsection{Chemical and Radioisotope Compositions}

Compositions are needed for (a) WM-188 liquid (see Section 4.3.1), (b) WM-188 and WM-189 undissolved solids, and (c) WM-187 solids. The composition of WM-187 solids will change as additional solids from other tanks are added to WM-187. Thus the immediate need is to obtain compositions of each of the tank solids (WM-187 as of early 2003, WM-181, WM-184, WM-185 and WM-186). Then after each one or two tanks are flushed to WM-187, additional samples should be taken and analyzed.

Major Crystalline Species. Major crystalline species could be identified in a small sample of solids by using x-ray diffraction, energy dispersive x-ray spectroscopy. SEM photos are also requested. This information is needed for material balances and to model precipitate formation in the tanks.

Chemical Analyses. Chemical analyses are needed to evaluate the performance of moderate and high temperature processes such as calcination and steam reforming. The chemical composition of the feed to these processes affects feed additive requirements, calciner/reformer operating conditions, materials of construction/corrosion, and off-gas composition, which in turn determines off-gas treatment requirements and design. Species that affect feed additive requirements and/or calciner/reformer waste properties are: $\mathrm{Al}, \mathrm{Na}, \mathrm{K}, \mathrm{Ca}, \mathrm{Si}, \mathrm{B}$ and $\mathrm{NO}_{3}$. Species that affect materials of construction and corrosion include $\mathrm{F}, \mathrm{Cl}, \mathrm{S}$ or $\mathrm{SO}_{4}, \mathrm{P}$ or $\mathrm{PO}_{4}$. Species that affect off-gas treatment requirements and equipment include $\mathrm{NO}_{3}, \mathrm{~S}$ or $\mathrm{SO}_{4}, \mathrm{Cl}, \mathrm{F}, \mathrm{Hg}, \mathrm{Pb}$ and $\mathrm{Cs}$. Other species such as $\mathrm{Fe}, \mathrm{Pd}$ or $\mathrm{Ru}$ may have catalytic effects in the reactor that could affect either the additive requirements, operating conditions or resulting off-gas composition. 
While not expected to be significant for the design, other species that would be of interest for the high temperature processes to "close the mass balance" or develop simulants for verification tests would include $\mathrm{Ba}, \mathrm{Cd}, \mathrm{Cr}, \mathrm{Se}, \mathrm{Zn}, \mathrm{Ce}, \mathrm{Cu}, \mathrm{Mg}, \mathrm{Mn}, \mathrm{Nb}, \mathrm{Sn}, \mathrm{Ti}, \mathrm{U}$ and $\mathrm{Zr}$.

Radionuclide Analyses. Radionuclide analyses are needed to (a) determine the disposal site of waste product, (b) confirm that the final waste will meet disposal site waste acceptance criteria, (c) confirm that the final waste will meet transportation requirements, and (d) determine dose rates and shielding requirements for processing equipment and the final waste package. The concentrations of the following isotopes are needed: ${ }^{241} \mathrm{Am},{ }^{137} \mathrm{Cs},{ }^{134} \mathrm{Cs},{ }^{244} \mathrm{Cm},{ }^{60} \mathrm{Co},{ }^{152} \mathrm{Eu},{ }^{154} \mathrm{Eu},{ }^{129} \mathrm{I},{ }^{237} \mathrm{~Np},{ }^{238} \mathrm{Pu},{ }^{239} \mathrm{Pu},{ }^{126} \mathrm{Sb},{ }^{90} \mathrm{Sr}$, ${ }^{99} \mathrm{Tc},{ }^{234} \mathrm{U},{ }^{235} \mathrm{U},{ }^{236} \mathrm{U}$, and ${ }^{238} \mathrm{U}$. Concentrations of radionuclide by particle size are desirable if possible. For example, the fines that pass through the solids filter are expected to contain radioactive cesium that could seriously affect the dose rate of grouted waste in the CsIX process. Also, the TRU content of these same fines will in part determine how the spent cesium sorbent in packaged for disposal and could also affect what disposal site the waste is sent to. Thus concentrations of ${ }^{137} \mathrm{Cs}$ and TRU species in a fines fraction of the solids are needed. 


\section{REFERENCES}

1. M. D. Staiger, C. B. Millet, R. A. Nichelson, R. A. Wood, A. Chambers, "Tank Farm Facility, Tank and Waste Data," Engineering Design File EDF-1598, February 27, 2001.

2. C. B. Millet, "Composition of Tank Farm Waste as of October 2002”, INEEL Interoffice Memorandum Mil-07-02, December 12, 2002.

3. J. D. Christian, Composition and Simulation of Tank WM-180 Sodium-Bearing Waste at the Idaho Nuclear Technology and Engineering Center, INEEL/EXT-2001-00600, May, 2001.

4. T. A. Batcheller, D. D. Taylor, V. J. Johnson, Characterization of Tank WM-189 Sodium-Bearing Waste at the Idaho Nuclear Technology and Engineering Center, INEEL/EXT-02-01171 Rev. 1, (draft) December, 2002.

5. M. Patterson, Light Duty Utility Arm Deployment in Tank WM-188, INEEL/EXT-99-01302, December 1999.

6. Idaho Hazardous Waste Management Act/Resource Conservation and Recovery Act Closure Plan for Idaho Nuclear Technology and Engineering Center Tanks WM-182 and WM-183, DOE/IC10802, Appendix B, "Data Summary for Tanks WM-182 and WM-183," DOE/ID-10802, November, 2001.

7. A. Poloski, "Solids Characterization," Engineering Design File EDF-TST-001, September 20, 2000 .

8. D. R. Tyson, "Validation of the Radionuclide Mass Balance Used in the INTEC SBW WIR Determination Report," Engineering Design File EDF-1920, Revision 4, August 29, 2002

9. M. C. Swenson, Historical Tank Farm Sample Results, MCS-27-92, December 17, 1992.

10. A. P. Poloski, "INTEC Tank Farm Sludge Density Measurements/Calculations," Engineering Design File 15722-040, July 12, 2000.

11. J. A. Nenni, "Balance-of-Plant Sample Data Compilation," Engineering Design File, EDF-2506, September 2002.

12. J. L. Tripp, Supporting Information for the INEEL Liquid Waste Management Plan, Appendix B, INEEL/EXT-98-00730, July, 1998.

13. C. M. Barnes, "NGLW Volumes and Compositions for Treatment Study," INEEL Interoffice Memorandum CMB-07-02, Rev. 1, April 8, 2002.

14. C. M. Barnes, C. B. Millet, INTEC Tank Farm Facility Management Plan, Plan-1112, September 30, 2002.

15. J. R. Harbour, R. F. Schumacher, A. Choi, A. K. Hansen, Development of an Initial Simulant for the Idaho Tank Farm Solids, WSRC-TR-2002-00436, November 11, 2002.

16. R. A. Wood, "Heel Solids Process Evaluation for the Idaho Tank Farm Project NWCF MACT Upgrade Option,” Engineering Design File EDF-3049, December 2002. 
17. M. C. Swenson, "Radiological and Fissile Material Source Term for Tank Farm Undissolved Solids,” INEEL Interoffice Correspondence MCS-06-02, November 7, 2002.

18. M. C. Swenson, "HLLWE Plugging Problems Associated with WM-186 Waste," INEEL Interoffice Correspondence MCS-04-01, May 30, 2001.

19. C. M. Barnes, R. A. Wood, B. H. O'Brien, "Process Design of SBW Treatment Alternatives," Engineering Design File EDF-2373, September 10, 2002.

20. K. J. Rebish, J. A. Nenni, “Tank Farm Inventory, 1994,” INEL Interoffice Correspondence KYR02-94/JAN-03-94, June 23, 1994.

21. C. M. Barnes, Feed Composition for the Sodium-Bearing Waste Treatment Process, INEEL/EXT2000-01378, Revision 1, July 2001.

22. C. M. Barnes, "Sodium-Bearing Waste Composition for Use in Treatment Evaluation," INEEL Interoffice Memorandum CMB-09-02, May 7, 2002.

23. D. Wenzel, "Relative Inventories of Reactor-Produced Species in INTEC Waste Types," Engineering Design File EDF-CRPD-001, November 4, 2002.

24. A. Poloski, "Reology of the INTEC Tank Farm Closure Surrogate and WM-182 LDUA Sample Dissolution of the WM-182 LDUA Sample in 6M Nitric Acid," Engineering Design File 1914, February 19, 2001.

25. HLW Program Office, Analysis of the HLW Calcined During the NWCF Campaign H-4, LMITCO Internal Report, INEEL/INT-98-00931, September 1998.

26. L. J. Young, N. R. Soelberg, B. H. O’Brien, R. D. Boardman, L. A. Matejka, M. L. Abbott, G. R. Hassel, NWCF Calciner Emissions Inventory - Final Report for Test Series 1, 2, and 3, INEEL/EXT-2000-00114, January, 2000, Part 2, Appendix F.

27. N. Soelberg, et. al, "Delisting Data Quality Objectives Project Organic Compound Stability Study," Revision 1 (unpublished), April 10, 2002.

28. D. Griffith, Tank Sampling and Characterization Plan, INEEL PLN-1129, September 26, 2002.

29. Balance of Plant Sampling and Analysis Plan for the INTEC Liquid Waste Management System, INEEL PLAN-613, Revision 2, May 15, 2002. 